\title{
Rapeseed meal as a supplementary protein for dairy cows on grass silage-based diet, with the emphasis on the Nordic AAT-PBV feed protein evaluation system
}

\author{
MIKKo TUORI \\ University of Helsinki \\ Department of Animal Science \\ SF - 00710 Helsinki, Finland
}

Academic Dissertation

To be presented with the permission of the Faculty

of Agriculture and Forestry of the University of Helsinki,

for public criticism in the Auditorium B2, Viikki,

on November 27, 1992 at 12 noon. 



\section{Acknowledgements}

The present experiments were conducted at the Department of Animal Science, University of Helsinki, with the exception of one conducted in Maaninka at the North Savo Research Station of the Agricultural Research Centre.

First and foremost, I would like to thank Professor Unto Tulisalo for suggesting rapeseed meal as the topic of this doctoral dissertation, and for his support and encouragement during the work. Further, I am indebted to Professor Liisa Syrjälä-Qvist for suggesting that the work be carried out the Department of Animal Science, for supervising several of the experiments, and for her unfailing support during the study. My heartfelt thanks go to our former Director, now Director General, Professor Esko Poutiainen for supervising the first experiment.

I am very grateful to Dr. Pekka Huhtanen for his advice and comments on the calculations, to Professor Matti Näsi for his preliminary comments on the manuscript, to Mr. Veijo Vilva for his advice on statistics, to Professor Vappu Kossila and Dr. Tuomo Varvikko for their constructive criticism on the manuscript.

Carrying out the experiments called for much work in the laboratory and with the animals, for which I am indebted to the staff of the Department of Animal Science, too numerous to be mentioned here. My special thanks go to Ms. Marjatta Suvitie, and Mr. Kalle Rinne, and the staff of North Savo Research Station for carrying out one of the experiments. Ms. Tuija Niskanen, Mr. Mikko Maisi, Ms. Heli-Maria Ojanperä, Ms. Aila Asikainen and Ms.Taina Voutilainen, who assisted in the experiments while undergraduate students, also deserve to be thanked.

Ms. Terttu Heikkilä, and Dr. Pekka Huhtanen have earned my gratitude by providing the milking trial data, and so has Mr. Vesa Toivonen for amino acids analyses and Ms. Aila Vanhatalo for determination of contents in the mobile bag tests at the Institute of Animal Production, Agricultural Research Center.

I would like to thank Ms. Liisa Fellman-Paul for translating the main body of text to English and Dr. Andrew Root and his wife Tarja, for checking the text of the tables and appendices etc.

The financial support provided by Öljynpuristamo Oy, and the Agricultural Research Foundation of August Johannes and Aino Tiura is acknowledged with gratitude.

Last, but far from least, my thanks to my wife Ritva, whose support and encouragement have helped me complete the work, and to my children Katri and Eeva for their patience during my long days at work.

\section{Mikko Tuori}

27 November 1992 


\section{TABLE OF CONTENTS}

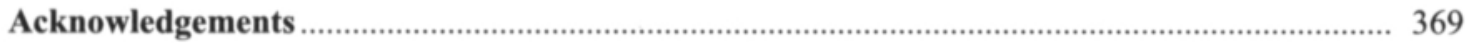

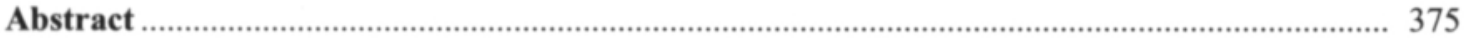

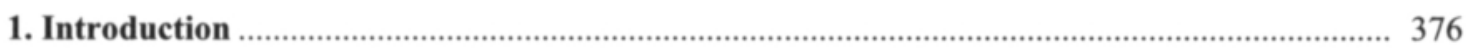

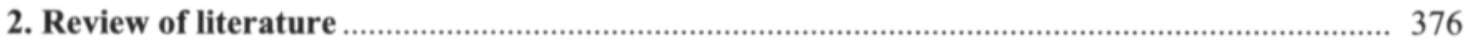

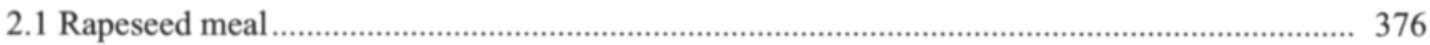

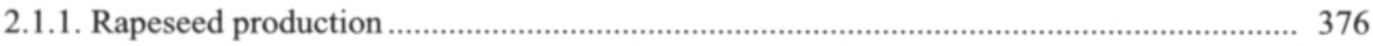

2.1.1.1. Origins and cultivation of turnip rape .............................................................. 376

2.1.1.2. Cultivation of rapeseed in Finland ............................................................... 378

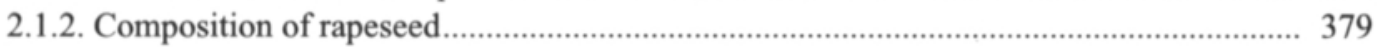

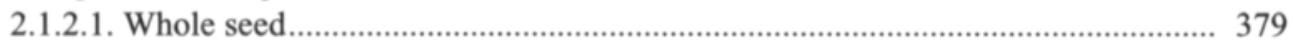

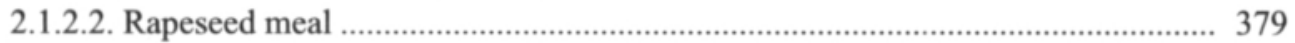

2.1.2.3. Rapeseed protein .......................................................................................... 380

2.1.2.4. Rapeseed fat ...................................................................................................... 381

2.1.2.5. Carbohydrates of rapeseed meal ................................................................ 382

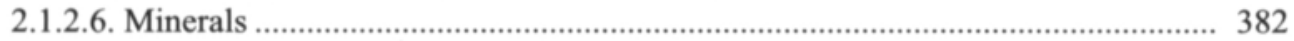

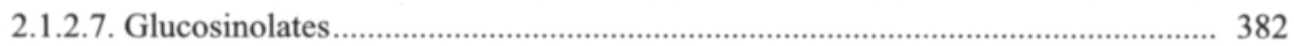

2.1.2.7.1. Structure and classification of rapeseed glucosinolates .................. 382

2.1.2.7.2. Analysis of glucosinolates in RSM .............................................. 384

2.1.2.7.3. Physiological effects of glucosinolates ........................................... 384

2.1.2.7.4. Glucosinolates in milk ................................................................. 385

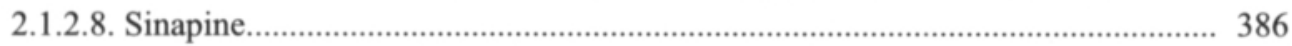

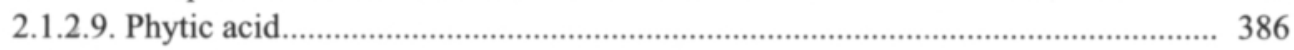

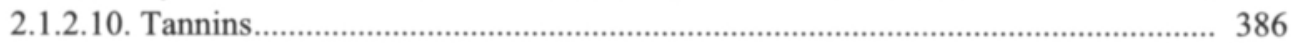

2.2. Rapeseed meal as a protein supplement for dairy cows ..................................................... 387

2.3. New systems for evaluating feed protein in dairy cattle ...................................................... 387

2.3.1. AAT-PBV feed protein evaluation system .................................................................. 387

2.3.1.1. Effective degradation of feed protein ........................................................... 388

2.3.1.2. Microbial nitrogen contamination of feed residues in bag ............................... 388

2.3.1.3. Small particle loss from the bag...................................................................... 388

2.3.1.4. Fractional outflow rate from the rumen ......................................................... 388

2.3.1.5. Efficiency of microbial protein synthesis ................................................... 389

2.3.1.6. Amino acid content and digestibility of duodenal proteins ............................... 391

2.3.1.7. Utilization efficiency of amino acids for lactation in dairy cows ...................... 391

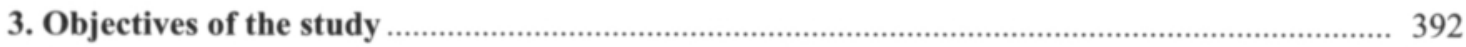

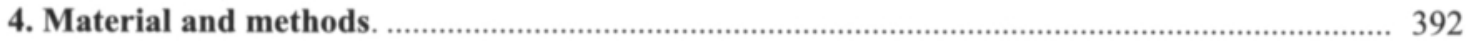

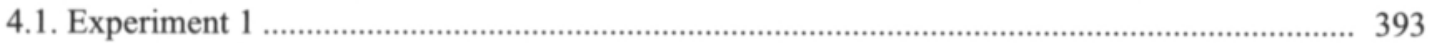

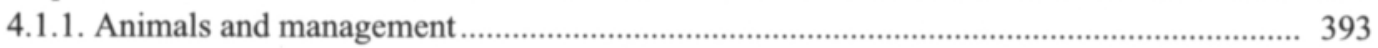

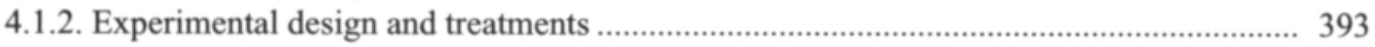

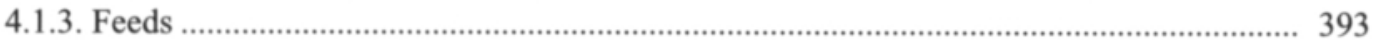




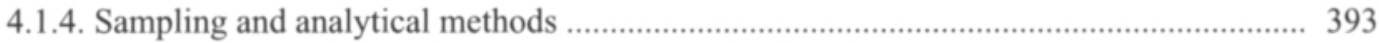

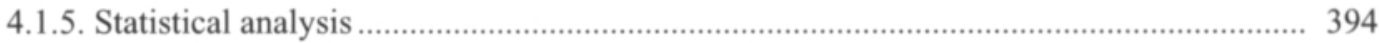

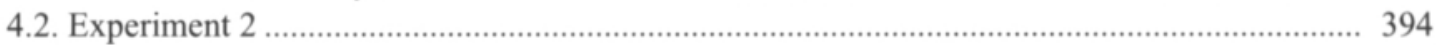

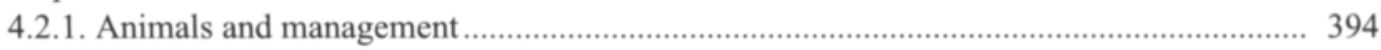

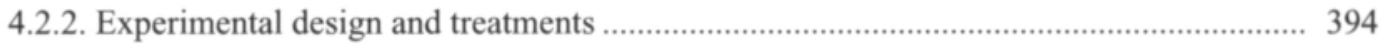

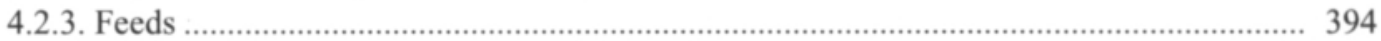

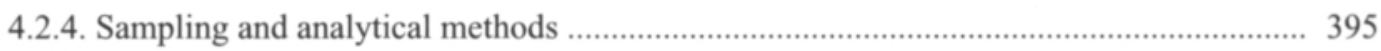

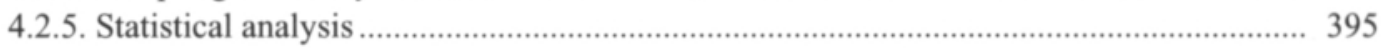

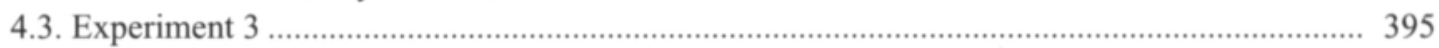

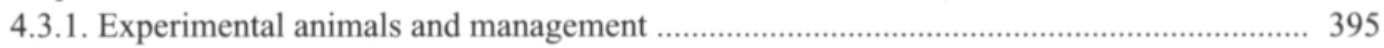

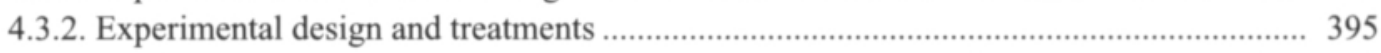

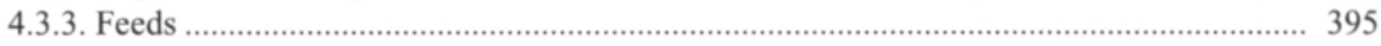

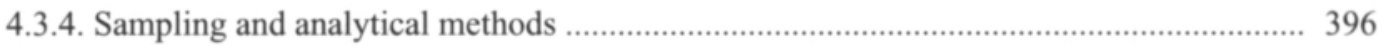

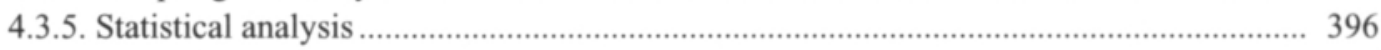

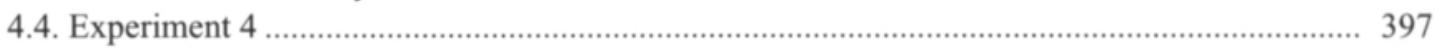

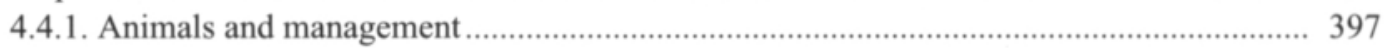

4.4.2. Experimental design and treatments ........................................................................... 397

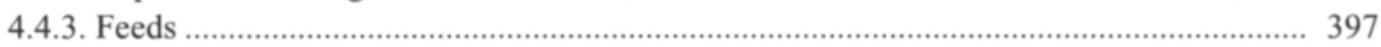

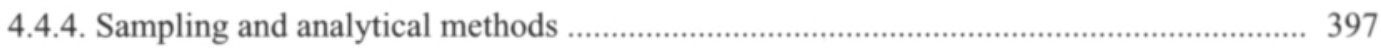

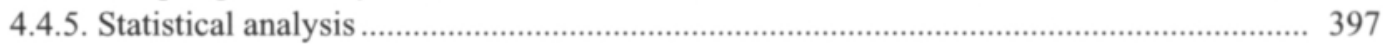

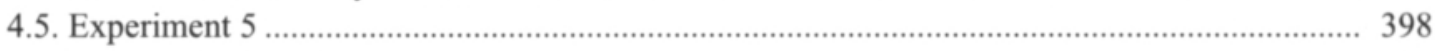

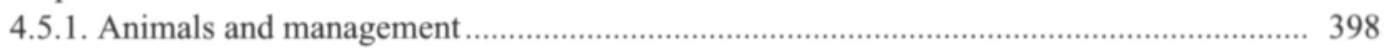

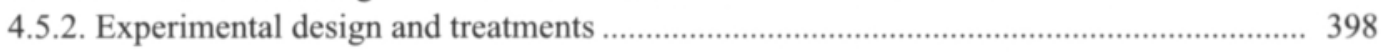

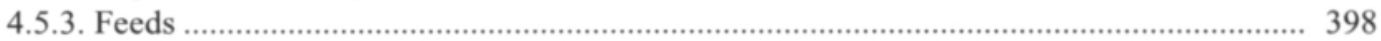

4.5.4. Sampling and analytical methods .......................................................................... 398

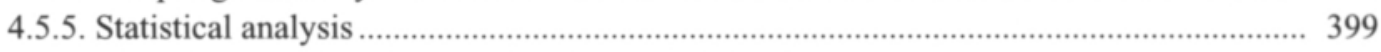

4.6. Estimating the effect of RSM on the milk and protein yield............................................... 399

4.7. Comparison of AAT-PBV and DCP systems..................................................................... 399

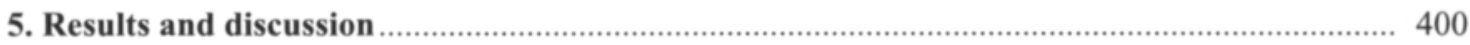

5.1. Composition and nutritional value of feeds ......................................................................... 400

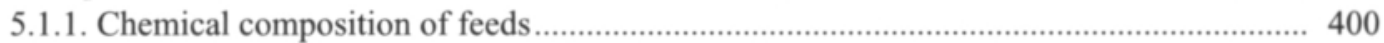

5.1.2. Intestinal degradation of RSM and SBM as measured by mobile nylon bag technique... 402

5.1.3. Amino acid content of RSM and SBM ..................................................................... 402

5.1.4. Glucosinolate content of RSM .................................................................................... 403

5.2. Effect of protein supplement on the digestibility of the diet ................................................. 405

5.3. Effect of proportion of RSM on milk production.................................................................... 405

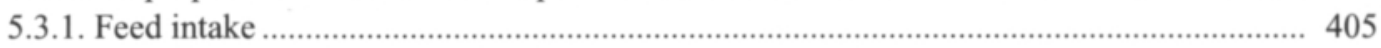

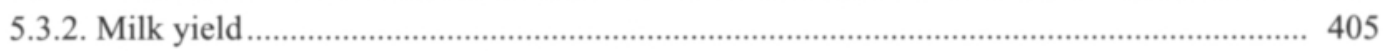

5.4. Effect of protein protection on milk yield and protein content …........................................ 410

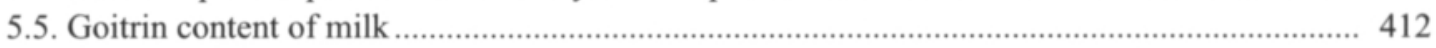

5.6. DCP and AAT protein evaluation systems in milk production .......................................... 413

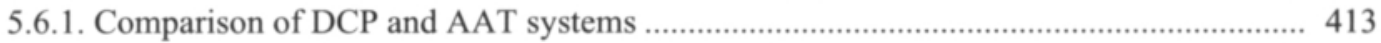

5.6.2. Effect of corrections of AAT-PBV values of RSM and other feeds............................... 414

5.6.3. Effect of corrections of AAT values on the utilization of feed protein .......................... 416 


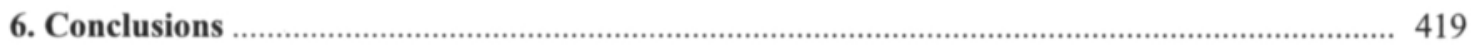

6.1. Glucosinolate content ......................................................................................................... 419

6.2. Effect of rapeseed meal on milk yield ................................................................................. 419

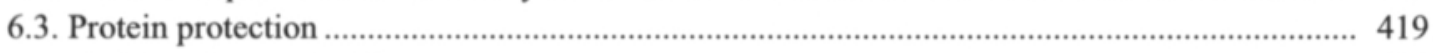

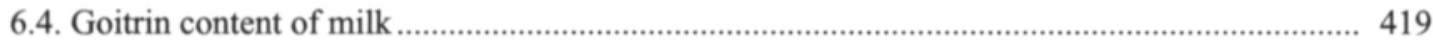

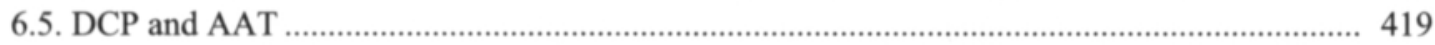

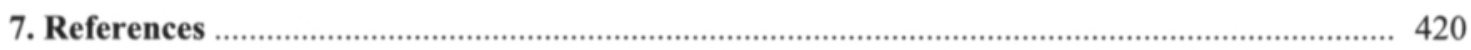

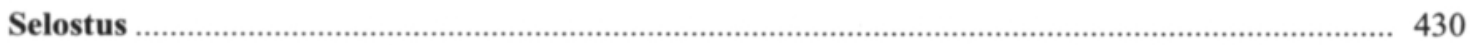

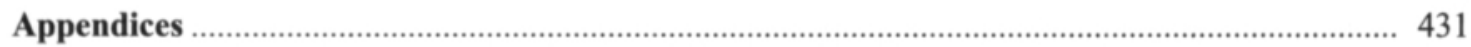




\title{
Rapeseed meal as a supplementary protein for dairy cows on grass silage-based diet, with the emphasis on the Nordic AAT-PBV feed protein evaluation system
}

\begin{abstract}
MIKKO TUORI
TUORI, M. 1992. Rapeseed meal as a supplementary protein for dairy cows on grass silage-based diet, with the emphasis on the Nordic AAT-PBV feed protein evaluation system. Agric. Sci. Finl. 1: 367-439. (Univ. Helsinki, Dept. Anim. Sci., SF - 00710 Helsinki, Finland.)

The effect of rapeseed meal (RSM) supplementation on the performance of dairy cows on direct cut grass silage based diets was studied in five feeding trials. The proportion of RSM varied from $0 \%$ to $33 \%$ in the concentrate mixture (the grain was an oat-barley mixture of 1:1). In one experiment the treatments were RSM and soybean meal (SBM), while in another experiment forage was either grass silage or barn dried hay cut at the same maturity. In addition, this was compared to the data of other trials in Finland during the last ten years, in which RSM supplementation had been used. Using this data the response in terms of milk yield to RSM supplementation was estimated. The utilization of protein in milk production was estimated by the Nordic AAT-PBV protein evaluation system.

During the experiments (1983-1990) the varieties of turnip rape were changed from high glucosinolate, containing single-zero, to low glucosinolate containing doublezero varieties, while the glucosinolate content was reduced from 40-50 $\mu$ moles to 14 $\mu$ moles per $g$ of defatted meal. Heat-moisture treatment ( ${ }^{\mathrm{TM}} \mathrm{O}$ pex) further reduced the glucosinolate content by half.

By replacing grain with RSM in the concentrate mixture with ad libitum silage feeding, the silage intake increased by $0.43 \mathrm{~kg}$ per $\mathrm{kg}$ increase in RSM on the basis of dry matter (DM) (non significant). The response in increased milk production was $0.77 \mathrm{~kg}$ in milk or $0.70 \mathrm{~kg}$ in energy corrected milk (ECM) yield $(\mathrm{P}<0.02)$, and in protein yield $27 \mathrm{~g} / \mathrm{d}(\mathrm{P}<0.01)$ per $\mathrm{kg}$ increase in RSM DM. Although the linear effect of the RSM level was significant, the effect on the milk yield was reduced when the level of RSM was over $12-16 \%$ of concentrate mixture. The protein content of milk increased by $0.07 \mathrm{~g} / \mathrm{kg}$ per $\mathrm{MJ}$ increase in metabolizable energy intake $(\mathrm{P}<0.02)$.

Heat-moisture treatment of RSM increased milk production significantly in one experiment (21.9 kg vs. $23.9 \mathrm{~kg}$ milk or 23.4 vs. $25.2 \mathrm{~kg} \mathrm{ECM} / \mathrm{d}),(\mathrm{P}<0.03)$. In two other experiments heat treatment had no noticeable effect on milk yield. In comparing SBM with RSM on the same crude protein basis in the concentrate, no difference in milk yield was observed.

The goitrin content of the milk was reduced when the glucosinolate content RSM, or the level of RSM in the diet, was reduced. With Öpex-treated double zero RSM, the milk contained less than $10 \mu \mathrm{g} / 1$ (sensitivity of analysis $2 \mu \mathrm{g} / \mathrm{l}$ ) goitrin.

The utilization of AAT in milk production was also estimated using different constants in the calculations of AAT-PBV values of the feeds. When the proportion of AAT of microbial origin increased, the coefficient of variation of the AAT utilization reduced. This is affected by correcting the microbial- $\mathrm{N}$ contamination of the in sacco analysis, lowering the estimate for the rumen outflow rate (k-value) from 0.08 to 0.03 , and changing the estimate for the efficiency of microbial protein synthesis (MPS). The best model was obtained using the method of VoIGT and PIATKOWSKI (1991) for calculating MPS.
\end{abstract}

Key words: dairy cows, rapeseed meal, grass silage feeding, protein protection, protein evaluation systems, AAT/PBV 


\section{Introduction}

In Finland milk production accounts for ca. $30 \%$ of the gross income from agriculture. The fact that most of the feeds can be produced on the farm, especially for dairy cattle on a grass silage-based diet, works in favour of dairy farming. Hence the proportion of forage in the total feed units averaged $55.4 \%$ in 1991 on milk recorded farms, the proportion of silage being $33.1 \%$. Forage was supplemented by grain and protein concentrates, the most important of which were soybean meal and rapeseed meal. In 1991 the combined production of oilseed meals and oil cakes totalled 190 million kilograms, of which $41 \%$ was of rapeseed and $59 \%$ of soybean. Rapeseed meal is given mainly to cattle, whereas soybean meal is mainly used in pig and poultry feeds, with only $20-25 \%$ used in cattle feed. Replacing a part of the soybean meal in cattle feed with rapeseed meal could increase the domestic cultivation of rape, thereby boosting the national self-sufficiency in cattle feeds. Rapeseed cultivation and production of rapeseed meal could increase in the future if rapeseed oil were used as a diesel fuel.

The production of feed protein for ruminants can be increased by using high amounts of nitrogen fertilizer in swards.This was demonstrated in the 1970 s by the so-called "Green line" project (Ettala and Lampila 1974, Ettala et al. 1974, Ettala et al. 1978). Grass silage of high crude protein content and high digestibility, supplemented with plain grain concentrate, will satisfy the requirement for digestible crude protein even at high production levels. However, supplementing grain with protein concentrates in a diet of forage with high crude protein content has also increased milk production (Castle and Watson 1976, Gordon and Murray 1979). This indicates that the DCP system has its limitations, and new systems were developed during the 1970 s and 1980 s. The new feed protein evaluation systems, for instance the Nordic AATPBV system (NKJ 1985), have divided the amino acid nitrogen absorbed in the duodenum into that of microbial origin and of feed origin, enabling the protein requirement of the dairy cow to be estimated more exactly than by using the DCP system. In the present study various rapeseed meals were used as supplements to the grass silage based-diet of dairy cows, and their effect on milk production and composition, as well as on the utilization of feed protein, was examined with the AAT-PBV system.

\section{Review of literature}

\subsection{Rapeseed meal}

\subsubsection{Rapeseed production}

\subsubsection{Origins and cultivation of turnip rape}

Among the most commonly cultivated oilseed plants the turnip rape comes third after soybean and linseed (Table 1). Since World War II it has become the most important oilseed plant in the

Table 1. World oilseed production.

\begin{tabular}{lrrrrrrrr}
\hline & $\begin{array}{l}1962- \\
1964\end{array}$ & $\begin{array}{l}1972- \\
1974\end{array}$ & $\begin{array}{l}1982- \\
1984\end{array}$ & $1986 / 87$ & $1987 / 88$ & $1988 / 89$ & $1989 / 90$ & $1990 / 91$ \\
\hline Soybeans & 30.4 & 53.7 & 89.9 & 98.1 & 103.7 & 95.4 & 106.0 & 104.3 \\
Cottonseed & 21.2 & 24.9 & 28.8 & 27.6 & 31.6 & 32.6 & 31.2 & 33.3 \\
Rapeseed & 4.0 & 7.3 & 15.3 & 19.8 & 23.5 & 20.4 & 21.5 & 24.0 \\
Sunflowerseed & 7.2 & 10.9 & 16.8 & 18.8 & 21.0 & 20.6 & 21.7 & 22.3 \\
Groundnuts & 10.7 & 11.1 & 13.2 & 15.0 & 15.1 & 16.2 & 15.6 & 15.9 \\
World") & 79.9 & 121.3 & 178.2 & 194.4 & 209.5 & 202.7 & 211.2 & 216.1 \\
\hline
\end{tabular}

\footnotetext{
1) Soybeans, cottonseed, rapeseed, sunflowerseed, groundnuts, copra, palmkernels, linseed Amounts shown are million metric tons; adapted from Toepfer International (1990)
} 
temperate zone. Traditionally rapeseed was cultivated in India, China and Japan. In Europe rapeseed was cultivated since the 14th century, although rape oil has only been used for cooking since the 1940 (Shahidi 1990a). Today China, Canada, India, France, Germany, Great Britain and Poland are important producers of rapeseed (Tables 2 and 3). According to the FAO statistics (FAO 1991) there was some rapeseed cultivation in forty countries in 1990.

The name "rape" in rapeseed was derived from the Latin word for turnip (rapum). Turnip, rutabaga, cabbage, Brussels sprout, mustard and many other common vegetables are closely related to rape. Rape grows in low temperatures and tolerates humidity, thus thriving in such temperature zones where soybean and sunflower do not survive.

DOWNEY and RöBBELEN (1989) studied the origins of the oilseed plants of the Brassica family. Certain species of the Brassica family may well be among the earliest known cultivated plant, as some vegetable forms of this family were commonly used as early as in the Neolithic age, and reference was made to oilseed rape and mustard in Indian Sanskrit texts from the 21 st to the 16 th century B.C. These plants and their medicinal qualities were also mentioned in Greek, Roman and Chinese texts from the 6 th to the 3 rd century B.C. In Europe rape cultivation did not begin until the early Middle Ages. The commercial cultivation of rape began in the Netherlands as early as in the 16th century. Rape oil was traditionally used as an illuminant (lamp oil) and lubricant for steam engines, gaining a notable market share among food oils in the West only after World War II, thanks to improved varieties and more efficient processing techniques (DOWNEY and RÖBBELEN 1989).

The major varieties of oilseed plants in the Brassica family are Brassica campestris or turnip rape, and $B$. napus or rape. The former originated in the high plateaus in Turkey, from where it spread two thousand years ago to cover an area from the islands in the western Atlantic Ocean to China and the East coast of Korea, from northern Norway to the Sahara and North India. Brassica napus is a cross between $B$. campestris and B. oleracea. The latter originates in the Mediterranean region, and it is generally accepted that $B$. napus originated in southern Europe (DOWNEY and RöBBELEN 1989).

There are spring and winter varieties of both $B$. campestris and $B$. napus. The winter varieties tend to yield more, but their wintering characteristics are poorer than those of winter grain crops.

Table 3. Rapeseed production in Europe.

\begin{tabular}{lrrrr}
\hline & $\begin{array}{r}1979- \\
1981\end{array}$ & 1988 & 1989 & 1990 \\
& 871 & 2469 & 1803 & 2011 \\
France & 618 & 1640 & 2869 & 2157 \\
Germany & 434 & 1199 & 1586 & 1206 \\
Poland & 274 & 1040 & 976 & 1231 \\
UK & 204 & 504 & 655 & 819 \\
Denmark & 165 & 380 & 387 & 380 \\
Czechoslovakia & 313 & 305 & 422 & 401 \\
Sweden & 68 & 121 & 125 & 117 \\
Finland & 3203 & 8076 & 8261 & 8754 \\
Europe, total & & & & \\
& & & &
\end{tabular}

Amounts shown are 1000 metric tons; adapted from FAO Yearbook 1990

Table 2. Rapeseed production of some important producers.

\begin{tabular}{lrrrrrrrr}
\hline & $\begin{array}{r}1962- \\
1964\end{array}$ & $\begin{array}{r}1972- \\
1974\end{array}$ & $\begin{array}{r}1982- \\
1984\end{array}$ & $1986 / 87$ & $1987 / 88$ & $1988 / 89$ & $1989 / 90$ & $1990 / 91$ \\
\hline Canada & 0.21 & 1.22 & 2.78 & 3.79 & 3.85 & 4.31 & 3.10 & 3.26 \\
PR China & 1.04 & 1.20 & 4.72 & 5.88 & 6.61 & 5.04 & 5.44 & 6.55 \\
India & 1.19 & 1.92 & 2.65 & 2.61 & 3.37 & 4.02 & 3.80 & 4.00 \\
Poland & 0.28 & 0.49 & 0.63 & 1.30 & 1.19 & 1.18 & 1.58 & 1.20 \\
EC-12 & 0.37 & 0.50 & 2.91 & 3.69 & 5.94 & 5.18 & 4.99 & 5.87 \\
\hline
\end{tabular}

Amounts shown are million metric tons; adapted from Toepfer International (1990) 
Breeding of the presently cultivated turnip rape and rape varieties has been pursued especially in Canada. B. campestris was imported to Canada in 1936 , and a few years later B. napus was brought from Argentina. Commercial rapeseed production began in 1942 in Canada, the objective being to produce lubricant for the Allied war machinery. The erucic acid content of rapeseed was high, as it is still today in the Asian countries, where rape oil containing between 22 and 60 per cent of erucic acid is still being produced (HEAR, or high erucic acid rapeseed). The first rapeseed varieties with reduced erucic acid content, yielding rape oil containing less than $5 \%$ erucic acid (zero variety, "single low" or "single zero" varieties), were bred in Canada in 1968. These varieties are also known as LEAR (low erucic acid rapeseed). The first varieties low in both erucic acid and glucosinolate were licensed in 1974 (the "double low" or "double zero" varieties), i.a. the "Tower" variety. The low glucosinolate character came from the Polish variety "Bronowski". A double zero yellow seeded variety of turnip rape, "Candle", was developed in 1976. Having a low fibre content it is called a triple low (or triple zero) variety (SHAHIDI 1990b).

The brand name "Canola" was assumed in Canada in 1979 for all double low varieties. Canola was defined as a rapeseed variety yielding oil containing less than 2 per cent erucic acid, from which a defatted rapeseed meal containing less than 30 $\mu$ moles/g glucosinolate can be produced. Glucosinolates include, among others, four aliphatic gluco- sinolates: gluconapin, progoitrin, glucobrassicanapin and napoleiferin (SHAHIDI 1990b).

\subsubsection{Cultivation of rapeseed in Finland}

In practice, the cultivation of oilseed plants began in Finland in 1942 with the sowing of Argentinean linseed flax, although fiber flax and hemp had been traditionally grown (VALLE 1953). To a small extent hemp had been grown for seed and oil production. Linseed flax was being studied from 1924 at the Agricultural Research Center and from 1939 at the Plant Breeding Institute of Hankkija Wholesale Cooperative, resulting in two Finnish linseed flax varieties, "Vaanila" and "Tikkurila" (Maa- ja metsätalousministeriö 1975). From 1947 to 1951 the annual linseed flax cultivation covered an area of 2,000 to 4,000 hectares, the seed harvest averaging only $652 \mathrm{~kg}$ per hectare (VALLE 1953).

The cultivation of winter turnip rape began towards the end of the 1940s (Table 4), and by 1959 the area under winter turnip rape cultivation had increased to 18,600 hectares. By 1976 the cultivation of winter varieties had ceased in favour of spring varieties of rape and turnip rape (PAHKALA and SOVERo 1988). Their combined cultivation area was at its largest in 1988 , totalling 82,900 hectares $(80,300$ spring turnip rape and 2,600 spring rape. The respective figures for 1991 were 59,300 and 1,700 hectares (National Board of Agriculture 1991a). The yield of spring turnip rape has averaged 1,500 kg/ha (Table 4), being 1,780 kg/ha in

Table 4. Rapeseed production in Finland.

\begin{tabular}{lrrrrrrrr}
\hline & $\begin{array}{r}1948- \\
1955\end{array}$ & $\begin{array}{r}1956- \\
1960\end{array}$ & $\begin{array}{r}1961- \\
1965\end{array}$ & $\begin{array}{r}1966- \\
1970\end{array}$ & $\begin{array}{r}1971- \\
1975\end{array}$ & $\begin{array}{r}1976- \\
1980\end{array}$ & $\begin{array}{r}1981- \\
1985\end{array}$ & $\begin{array}{r}1986- \\
1990\end{array}$ \\
\hline $\begin{array}{l}\text { Area, } \\
1000 \text { ha }\end{array}$ & 10.8 & 9.9 & 6.7 & 5.1 & 10.1 & 31.7 & 61.1 & 76.6 \\
$\begin{array}{l}\text { Yield, } \\
\text { kg/ha }\end{array}$ & 1210 & 1120 & 1140 & 1440 & 1430 & 1530 & 1470 & 1530 \\
$\begin{array}{l}\text { Production, } \\
1000 \text { t/year }\end{array}$ & 12.5 & 11.3 & 7.5 & 7.6 & 14.6 & 47.8 & 88.3 & 115.4 \\
\hline
\end{tabular}

Adapted from National Bord of Agriculture, Helsinki, Finland. 
1990, when the corresponding figure for spring rape was $2,090 \mathrm{~kg} / \mathrm{ha}$ (National Board of Agriculture 1991a).

The first single zero varieties were brought to Finland in 1976, followed later by double zero varieties. In 1982 fifteen per cent of the spring turnip rape cultivated was of double zero varieties, whereas the corresponding share of spring rape was as high as nearly 70 per cent. At that time turnip rape covered $89.5 \%$ of the total rapeseed cultivation area. By 1988 the double zero varieties covered some 70 per cent of all spring turnip rape (varieties "Kova" and "Valtti"), and almost all spring rape ("Topas”) (National Board of Agriculture 1991b).

\subsubsection{Composition of rapeseed}

\subsubsection{Whole seed}

The properties of the whole seed of the turnip rape have been reviewed (e.g. RÖBBELEN and THIES 1980, Bell 1984, Bertram et al. 1986, HenKel and MosENTHIN 1989). The seeds of rape and turnip rape are normally black, reddish brown, or occasionally yellow in colour, and round, with a diameter ranging from 1.5 to $3.2 \mathrm{~mm}$. Winter rape has the largest seeds. The ripe rapeseed comprises an embryo ( 84 to 86 per cent of the dry weight) and a hull with a single cell layer of adhering aleuron as the only remains of the endosperm. The embryo consists mainly of two large cotyledons with an oil content of about 50 per cent. The cotyledons contain protein granules similar to those in the aleuron layer (BENGTSSON et al. 1972).

The proportion of the hull is between $13.0 \%$ and $18.7 \%$ of the dry weight of the rapeseed (APPELQVIST 1972 , BERTRAM et al. 1986), or $27 \%$ to $30 \%$ of rapeseed meal after the extraction of oil. The black or brown seeds have thicker hulls than the yellow seeds. The hull still contains 9 to 13 per cent hexane-soluble fat and 15 to 18 per cent protein in addition to fibre, its main ingredient. The dark colour of the hull is mainly due to condensed polyphenols. Of the undesirable constituents of the seed, glucosinolate and sinapine are mainly found in the core, whereas tannins are in the hull (BERTRAM et al. 1986, HeNKEL and MOSENTHIN 1989).

The oil content of the rapeseed varies from one species or variety to another. In winter rape it typically ranges from 42 to 50 per cent and in spring rape from 37 to 47 per cent of the dry matter. The respective figures for turnip rape are 40 to 48 per cent and 36 to 46 per cent (APPELQVIST 1972). After the extraction of fat the rapeseed meal contains roughly 40 per cent crude protein, depending on the species and variety. For instance, in 1969 in Canada the protein content of the defatted meal (DM) varied from 33.0 to 47.9 per cent (APPELQVIST 1972).

\subsubsection{Rapeseed meal}

Industrially the oil can be removed from the rapeseed either by pressing or by pressing and extracting with hexane. Before pressing, the crushed rapeseed is, when necessary, first dried, then purified, flaked and cooked in a stacked cooker in a temperature between $75^{\circ}$ and $85^{\circ} \mathrm{C}$, usually for 20 to 40 minutes (UNGER 1990). Continuous action expellers or screw presses are normally used for pressing most of the oil from the seed. The fat content of the remaining rapeseed cake varies between 15 and 18 per cent. The rapeseed cake is then subjected to an extraction process using hexane in a temperature of about $55^{\circ} \mathrm{C}$. After extraction the rapeseed meal (RSM), which contains from $1.5 \%$ to $5 \%$ fat, is toasted at $100^{\circ} \mathrm{C}$, dried and allowed to cool before storage (CARR 1989).

Rapeseed meal differs from rapeseed in that most of the oil has been removed. The removal of oil radically alters the composition of rapeseed, as the remaining fractional ingredients are then concentrated. In terms of a normal proximate analysis of feeds, roughly $12 \%$ of rapeseed meal consists of crude fibre, mainly in the form of the hulls (BELL and JEFFERS 1976).

The crude fat content of rapeseed meal depends on the quantity of oil left in the meal. The crude fat content, on average $4.1 \%$ of $\mathrm{DM}$, includes the 
remaining oil, the impurities removed from the oil during purifying, and other compounds, the largest group of which being phosphatides (gums) (BELL and JEFFERS 1976).

The crude protein content of rapeseed meal $(\mathrm{N} \mathrm{x}$ 6.25 ) is roughly $40 \%$ of the defatted meal. The crude protein content of the hull ranges from $12 \%$ to $16 \%$ depending on the proportion of remaining embryonic matter, whereas that of the embryonic matter is about $52 \%$ (BELL 1984). The average composition of Finnish rapeseed meal and cake is shown in Table 5.

\subsubsection{Rapeseed protein}

The main proteins in the seed are water-soluble albumin and salt-soluble globulin. Albumins form a major part of the metabolically active, vitally important protein in the cell. Albumins can also function as storage proteins. Regarding their amino acid composition, albumins are better dietary than storage proteins, especially as far as dietary sulphur-containing amino acids are concerned (NORTON 1989). The storage protein is located in

Table 5. Composition of the Finnish rapeseed meal and cakes $1989^{1)}$.

\begin{tabular}{|c|c|c|c|c|c|}
\hline & & $\begin{array}{l}\text { Rapeseed } \\
\text { Crude fat } \\
<5 \%\end{array}$ & $\begin{array}{l}\text { meal } \\
\text { Crude fat } \\
5-7 \%\end{array}$ & $\begin{array}{l}\text { Crude fat } \\
>7 \%\end{array}$ & $\begin{array}{l}\text { Rapeseed } \\
\text { cake }\end{array}$ \\
\hline \multicolumn{2}{|l|}{ No of samples } & 13 & 23 & 9 & 31 \\
\hline \multicolumn{6}{|c|}{ In dry matter $(\%)$} \\
\hline \multirow[t]{2}{*}{ Ash } & $\overline{\mathrm{x}}$ & 8.3 & 8.1 & 7.8 & 7.1 \\
\hline & $\mathrm{CV}$ & V 5.0 & 23 & 2.3 & 5.2 \\
\hline \multirow{2}{*}{ Crude protein } & $n \bar{x}$ & 37.9 & 37.9 & 36.5 & 33.8 \\
\hline & $\mathrm{CV}$ & V 5.2 & 4.4 & 2.9 & 5.8 \\
\hline \multirow[t]{2}{*}{ Crude fat } & $\overline{\mathrm{x}}$ & 4.1 & 5.3 & 7.7 & 17.2 \\
\hline & $\mathrm{CV}$ & V 20.8 & 17.4 & 9.6 & 14.4 \\
\hline \multirow[t]{2}{*}{ Crude fibre } & $\overline{\mathbf{x}}$ & 13.8 & 13.3 & 13.3 & 11.1 \\
\hline & $\mathrm{CV}$ & V 6.2 & 7.9 & 7.4 & 8.0 \\
\hline
\end{tabular}

${ }^{1)}$ Mean and coefficient of variation (\%)

Adapted from Valtion maatalouskemian laitos (1989) the so-called protein bodies or aleuron grains (APPELQVIST 1972).

The majority of rapeseed proteins are storage proteins without enzymatic activity. Between $18 \%$ and $28 \%$ of the crude protein in the seed consists of sedimentation coefficient $12 \mathrm{~S}$, a globulin also known as crucipherin (BHATTY et al. 1968, SCHWENKE et al. 1973b). It is a neutral protein, soluble in sodium chloride, with a molecular weight of 300,000 to 360,000 (SCHWENKE 1990). The $2 \mathrm{~S}$ proteins are water soluble, alkaline albumins known as napins. Their molecular weight ranges from 12,000 to 14,000 . They account for about $40 \%$ of the protein content of the seed (SCHWENKE et al. 1973b). Albumins are relatively rich in sulphurous amino acids (cystine 6.9\%) and lysine (9.0\%) (SCHWENKE et al. 1973a). A newly identified group of proteins, oleosines, make up ca. $20 \%$ of the protein content of the rapeseed. They are believed to be efficient emulsifying agents in the dry seeds (MurPHY et al. 1991).

Rapeseed meal includes more amino acids (AA) containing sulphur and slightly less lysine than soy-

Table 6. Essential amino acid composition of rapeseed meal and rapeseed hulls compared with soybean meal (BELL 1984).

\begin{tabular}{|c|c|c|c|c|c|c|}
\hline & \multicolumn{3}{|c|}{ In dry matter $(\%)$} & \multicolumn{3}{|c|}{$\begin{array}{l}\text { In crude } \\
\text { protein }(\mathrm{N} \times 6.25)\end{array}$} \\
\hline & $\begin{array}{l}\text { Rape- } \\
\text { seed } \\
\text { hulls }^{\mathrm{a}}\end{array}$ & meal $^{\mathrm{b})}$ & $\begin{array}{l}\text { Soy- } \\
\text { bean } \\
\text { meal }\end{array}$ & $\begin{array}{l}\text { Rape- } \\
\text { seed } \\
\text { hulls }\end{array}$ & meal & $\begin{array}{l}\text { Soy- } \\
\text { bean } \\
\text { meal }\end{array}$ \\
\hline Arginine & 0.28 & 2.50 & 3.26 & 2.49 & 6.11 & 6.44 \\
\hline Histidine & 0.11 & 1.15 & 1.21 & 0.98 & 2.81 & 2.40 \\
\hline Isoleucine & 0.45 & 1.63 & 2.37 & 4.00 & 3.98 & 4.69 \\
\hline Leucine & 0.62 & 2.85 & 3.79 & 5.51 & 6.97 & 7.49 \\
\hline Lysine & 0.66 & 2.45 & 3.14 & 5.87 & 5.98 & 6.22 \\
\hline Methionine & trace & 0.73 & 0.71 & trace & 1.78 & 1.40 \\
\hline Cystine & 0.24 & 0.50 & 0.33 & 2.13 & 1.23 & 0.65 \\
\hline Tryptophfan & 0.05 & 0.48 & 0.61 & 0.40 & 1.16 & 1.20 \\
\hline Phenylalanine & 0.43 & 1.64 & 2.43 & 3.82 & 4.01 & 4.80 \\
\hline Valine & 0.67 & 2.09 & 2.53 & 5.96 & 5.11 & 5.00 \\
\hline Threonine & 0.69 & 1.84 & 1.92 & 6.13 & 4.50 & 3.80 \\
\hline $\begin{array}{l}\text { Protein } \\
(\mathrm{Nx} 6.25, \%)\end{array}$ & 11.25 & 40.95 & 50.57 & 100 & 100 & 100 \\
\hline
\end{tabular}

a) Finlayson 1974, b) Clandinin et al.(1981), SARWAR et al. 1981 
bean meal (Table 6). The amino acids of Finnish rapeseed meal have been found to contain $5.4 \%$ to $5.9 \%$ lysine, $4.3 \%$ to $4.4 \%$ threonine, $2.3 \%$ to $2.5 \%$ methionine and $2.3 \%$ to $2.5 \%$ cystine (percentage of crude protein) (NÄSI 1991, NÄSI and SILJANDERRASI 1991).

\subsubsection{Rapeseed fat}

The rapeseed fats are predominantly, more than $90 \%$, triglycerides. In addition, there are less than $4 \%$ phospholipids, the most important one being lecithin (Table 7).

Table 7. Fat composition of low erucic rapeseed (ZADERNOWSKI \& SOSULSKI 1978).

\begin{tabular}{lc}
\hline Triglycerides & $92.1 \%$ \\
Diglycerides & 1.2 \\
Free fatty acids & 0.5 \\
Sterol esters & 1.1 \\
Sterols & 0.6 \\
Phospholipids & 3.6 \\
Glycolipids & 0.9 \\
\hline
\end{tabular}

The fatty acid composition of rapeseed fats depends primarily on the variety (Table 8). Formerly varieties high on erucic acid, with erucic acid contents ranging from $45 \%$ to $50 \%$ of all fatty acids, were cultivated. In the 1960 s rapeseed oil caused an unusually high incidence of cardiac defects in laboratory animals, presumably due to erucic acid. As this phenomenon was not observed in humans, the nutritional risk may have been exaggerated (ACKMAN 1990). The EEC Commission set the upper limit for erucic acid content at $15 \%$ in 1976 , the present limit of $5 \%$ having been introduced in 1979. Low erucic acid rapeseed, i.e. single zero varieties, have an erucic acid content of less than $2 \%$ of all fatty acids (WARD et al. 1985). In Finland erucic acid content has been below $1 \%$ for several years.

Rapeseed oil contains less linoleic acid, but more $\alpha$-linolenic acid than soybean oil. Linoleic acid, also known as Vitamin F, tends to reduce the blood cholesterol level. The proportion of linoleic acid is higher in low erucic acid rapeseed varieties. A high linolenic acid content is an undesirable trait, as this

Table 8. Comparison of major fatty acids in some edible vegetable oils of commerce ( $w / w \%$ fatty acids).

\begin{tabular}{|c|c|c|c|c|c|c|c|c|c|c|c|}
\hline Fatty acids & HEAR $^{a}$ & LEAR $^{b}$ & Candlec & Tower ${ }^{d}$ & Soybean & Corn & Safflower & Sunflower & Peanut & Olive & Linseed \\
\hline $14: 0$ & - & 0.04 & 0.05 & 0.05 & 0.1 & - & 0.1 & - & 0.1 & - & - \\
\hline $16: 0$ & 4 & 3.48 & 3.55 & 3.88 & 10.8 & 11.4 & 6.5 & 6.2 & 10.0 & 11.0 & 5.5 \\
\hline 18:0 & 1 & 1.50 & 1.38 & 1.56 & 4.0 & 1.9 & 2.3 & 4.7 & 2.3 & 2.2 & 4.3 \\
\hline $20: 0$ & 1 & 0.42 & 0.43 & 0.50 & - & - & - & - & - & - & - \\
\hline $22: 0$ & $<1$ & 0.27 & 0.20 & 0.28 & - & - & - & - & - & - & - \\
\hline \multicolumn{2}{|c|}{ Total saturated 6} & 5.71 & 5.61 & 6.46 & 15.1 & 13.3 & 10.4 & 10.8 & 17.8 & 13.5 & 9.8 \\
\hline $16: 1$ & - & 0.22 & 0.28 & 0.29 & 0.2 & - & 0.4 & - & 0.1 & 0.8 & - \\
\hline $18: 1$ & 15 & 61.65 & 55.58 & 64.02 & 23.8 & 25.3 & 12.2 & 20.4 & 47.1 & 75.8 & 21.1 \\
\hline $20: 1$ & 10 & 1.38 & 1.78 & 1.24 & 0.2 & - & - & - & 1.4 & 0.3 & - \\
\hline $22: 1$ & 45 & 0.44 & 1.63 & 0.08 & - & - & - & - & - & - & - \\
\hline \multicolumn{12}{|c|}{ monounsaturated } \\
\hline $18: 2 n-6$ & 14 & 19.69 & 21.87 & 18.79 & 53.3 & 60.7 & 77.4 & 68.8 & 33.6 & 8.3 & 13.3 \\
\hline $18: 3 n-3$ & 9 & 10.65 & 12.99 & 8.59 & 7.1 & 0.7 & 0.4 & - & - & 0.6 & 55.7 \\
\hline $\begin{array}{l}\text { Total } \\
\text { polyunsatura }\end{array}$ & $\begin{array}{r}13 \\
\text { ated }\end{array}$ & 30.34 & 34.86 & 27.61 & 60.6 & 61.4 & 77.8 & 68.8 & 33.6 & 8.8 & 69.0 \\
\hline
\end{tabular}

Adapted from ACKMAN (1990)

${ }^{a}$ HEAR =high erucic acid rapeseed; ${ }^{b}$ LEAR $=$ low erucic acid rapeseed, $B$. campestris var. Torch

${ }^{\mathrm{c}}$ B. campestris var. Candle; ${ }^{\mathrm{d}}$ B. napus var. Tower 
acid oxidates easily, giving the oil an unpleasant odour. The oleic acid content of rapeseed oil is notably higher than that of soybean, the former resembling olive oil in this respect. Oleic acid has assumed increasing significance in recent studies on nutrition (ACKMAN 1990).

\subsubsection{Carbohydrates of rapeseed meal}

RSM comprises about $50 \%$ crude fibre and fractions of nitrogen-free extract. Hulled RSM contains roughly one third carbohydrate, one half protein (\% $\mathrm{N} x$ 6.25), and various other minor constituents. There are relatively small quantities of monosaccharides and disaccharides, starch being almost non-existent. The composition of carbohydrates in hulled rapeseed meal is $14.5 \%$ pectin, $7 \%$ cellulose residues, $4.5 \%$ amyloid, $2 \%$ arabinan, and $1 \%$ arabinogalactan (BELL 1984). Hulled rapeseed meal also contains protein (52\%), lignin (2.6\%), sinapine $(2.4 \%)$, ash $(3.7 \%)$, phytates $(2 \%)$ and glucosinolates (1\%). Dry RSM matter contains about $10 \%$ soluble sugars. THEANDER and ÅmAN (1976) reported $6.8 \%$ to $7.5 \%$ sucrose, $2.4 \%$ stachyose, $0.3 \%$ raffinose and $0.2-0.5 \%$ fructose in a moisture-free defatted turnip rape meal. $\alpha$ galactocides of sucrose, containing raffinose and stachyose, cannot be absorbed by the human digestive system, as it lacks the enzyme $\alpha$-galactosidase required for their hydrolysis. This has been observed to cause flatulence in humans and animals (NACZK and SHAHIDI 1990).

Hull mass amounts to about $16 \%$ of the weight of the full seed, and $30 \%$ of the oil-free RSM. The hulls contain $34 \% \mathrm{~N}$-free extract, $44 \%$ crude fibre, $14.5 \%$ pentosans, $32 \%$ cellulose, $3.8 \%$ sugars, $12 \%$ to $24 \%$ lignin, $6 \%$ to $12 \%$ polyphenols and $1.5 \%$ tannins (BELL 1984). Lignin content is lower in triple zero rapeseed varieties. THEANDER et al. (1977) reported $7.9 \%$ lignin in the hulls of yellowhulled turnip rapeseed. The digestibility of hull energy has been found to be very low in pigs, ranging from $0 \%$ (brown hulls) and $30 \%$ (yellow hulls) (BELL and SHIRES 1982).

\subsubsection{Minerals}

The mineral content of RSM was reviewed by BELL (1984). RSM dry matter contained $7.4 \%$ to $7.6 \%$ ash, $0.68 \%$ calcium and $1.2 \%$ to $2 \%$ phosphorus, of which nearly two thirds was phytin-bound phosphorus. In addition, the RSM dry matter contained $1.3 \%$ potassium, $0.64 \%$ magnesium, $0.8 \%$ to $1.7 \%$ sulphur and only $0.026 \%$ sodium (SUMMERS et al. 1983). The phytin content of the rapeseed calls for careful attention when formulating a diet, as is the case with cereal grain and oilseed meal in general. Availability of RSM phosphorus to young chickens does not exceed 30\% (SUMMERS et al. 1983).

\subsubsection{Glucosinolates}

2.1.2.7.1. Structure and classification of rapeseed glucosinolates

The presence of glucosinolates and phenolic choline esters in rapeseed limits its use as a feed for many animal species. Glucosinolates are an integral group of sulphur-containing anions present in nature, the structure of which was studied by ETTLINGER and LUNDEN (1954). More than 100 different glucosinolates are known today (SøRENSEN 1990).

The basic structure of glucosinolates is as follows:<smiles></smiles>

Glucosinolates can be classified as alkenyleglucosinolates and indolylglucosinolates on the basis of their side chain. In the former the $\mathrm{R}$ is straightchained, in the latter it is heterocyclic. Glucosinolates are hydrophilic and strongly acidic compounds, isolated and handled as salts. The glucosinolates of the species Brassica are derived biosynthetically from three amino acids: methionine, phenylalanine and tryptophan. About 30 different glucosinolates have been found in the seed of Bras- 
sica napus (SøRENSEN 1990). Glucosinolates numbered 1 to 15 in Table 9 can be derived from methionine, 14 to 22 from phenylalanine, and 23 to 27 from tryptophan (SøRENSEN 1990).

The following glucosinolates present in B. napus

Table 9. Selected glucosinolates important for the quality of rapeseed and other cruciferous corps (SøRENSEN 1990).

\begin{tabular}{|c|c|c|}
\hline No. & Trivial names & Semisystematic names \\
\hline \multicolumn{3}{|c|}{ Glucosinolates derived from methionine: } \\
\hline 1 & Sinigrin & Allylglucosinolate \\
\hline $2 \mathrm{CE}$ & Gluconapin & But-3-enylglucosinolate \\
\hline $3 \mathrm{CE}$ & Glucobrassicanapin & Pent-4-enylglucosinolate \\
\hline $4 \mathrm{CE}$ & Progoitrin & $\begin{array}{l}\text { (2R)-2-Hydroxybut-3- } \\
\text { enylglucosinolate }\end{array}$ \\
\hline 5 & Epiprogoitrin & $\begin{array}{l}\text { (2S)-2-Hydroxybut-3- } \\
\text { enylglucosinolate }\end{array}$ \\
\hline $6 \mathrm{CE}$ & Napoleiferin & $\begin{array}{l}\text { (2R)-2-Hydroxypent-4- } \\
\text { enylglucosinolate }\end{array}$ \\
\hline 7 & Glucoibervirin & 3-Methylthiopropylglucosinolate \\
\hline 8 & Glucoerucin & 4-Methylthiobutylglucosinolate \\
\hline 9 & Glucoberteroin & 5-Methylthiopentylglucosinolate \\
\hline 10 & Glucoiberin & 3-Methylsulphinylpropylglucosinolate \\
\hline 11 & Glucoraphanin & 4-Methylsulphinylbutylglucosinolate \\
\hline 12 & Glucoalyssin & 5-Methylsulphinylpentylglucosinolate \\
\hline 13 & Glucoraphenin & $\begin{array}{l}\text { 4-Methylsulphinylbut-3- } \\
\text { enylglucosinolate }\end{array}$ \\
\hline 14 & Glucocheirolin & $\begin{array}{l}\text { 3-Methylsulphonylpropyl- } \\
\text { glucosinolate }\end{array}$ \\
\hline 15 & Glucoerysolin & 4-Methylsulphonylbutylglucosinolate \\
\hline
\end{tabular}

Glucosinolates derived from phenylalanine:

\begin{tabular}{|c|c|c|}
\hline 16 & Glucotropaeolin & Benzylglucosinolate \\
\hline 17 & Gluconasturtiin & Phenethylglucosinolate \\
\hline 18 & Glucobarbarin & $\begin{array}{l}\text { 2-Hydroxy-2-phenylethyl- } \\
\text { glucosinolate }\end{array}$ \\
\hline & Glucolepigramin & $\mathrm{m}$-Hydroxybenzylglucosinolate \\
\hline & Sinalbin & p-Hydroxybenzylglucosinolate \\
\hline & Glucolimnanthin & m-Methoxybenzylglucosinolate \\
\hline & Glucoaubrietin & p-Methoxybenzylglucosinolate \\
\hline
\end{tabular}

Indol-3-ylmethylglucosinolates biosyntetically derived from typtophan:

$23 \mathrm{E}$ Glucobrassicin Indol-3-ylmethylglucosinolate

24 Neoglucobrassicin N-Methoxyindol-3-ylmethylglucosinolate

25 Sulphoglucobrassicin N-Sulphoindol-3-ylmethyl-

26 E 4-Hydroxygluco- 4-Hydroxyindol-3-ylmethylbrassicin glucosinolate

27 4-Methoxygluco- 4-Methoxyindol-3-ylmethylbrassicin glucosinolate

C: Glucosinolates standard by Canola Council

E: Glucosinolates standard by EEC are quantitatively the most prominent (SANG and SALISBURY 1988):

I Gluconapin

II Progoitrin

III Glucobrassicanapin

IV Napoleiferin

V Glucobrassicin

VI 4-hydroxyglucobrassicin

VII Sinigrin

VIII Gluconasturtiin

In addition to the four alkenylglucosinolates (gluconapin, progoitrin, glucobrassicanapin and napoleiferin) defined in the Canola standard, the quantities of the indolylglucosinolates glucobrassicin and 4-hydroxyglucobrassicin are included in the total glucosinolate content as defined in the EEC standard (EEC 210/55, ref. SCHNUG and HANEKLAUS 1988). After 1991 the total glucosinolate content of the rapeseed produced in the EEC countries may not exceed $20 \mu$ moles/g in air-dry seed. In the double zero varieties the quantity of alkenylglucosinolate is reduced, resulting in a relative increase in indolylglucosinolate content (mainly 4-hydroxyglucobrassicin) (Table 10).

Glucosinolates are not toxic as such, but become so during enzymatic degradation. The release of myrosinase enzymes (thioglucoside glucohydrolase, EC 3.2.1), present in plant cells and synthe-

Table 10. Content of glucosinolates in some rapeseed cultivars (SANG \& SAlisBury 1988).

\begin{tabular}{|c|c|c|}
\hline \multirow[t]{2}{*}{ Glucosinolate } & Brassica campestris & Brassica napus \\
\hline & $\begin{array}{ll}\text { Candle } & \text { Torpe } \\
\text { (Canada) } & \text { (Sweden) }\end{array}$ & $\begin{array}{ll}\text { Oro } & \text { Regent } \\
\text { (Canada) } & \text { (Canada) }\end{array}$ \\
\hline
\end{tabular}

Glucosinolates (percentage of total amount)

\begin{tabular}{|c|c|c|}
\hline Gluconapin & 31 & 12 \\
\hline Progoitrin & 25 & 68 \\
\hline Glucobrassicanapin & 26 & 6 \\
\hline Napoleiferin & 6 & 5 \\
\hline Glucobrassicin & tr & tr \\
\hline 4 - hydroxyglucobrassicin 7 & 7 & 5 \\
\hline Sinigrin & 0 & 2 \\
\hline Gluconasturtiin & 6 & 2 \\
\hline $\begin{array}{l}\text { Total glucosinolates } \\
\text { ( } \mu \text { moles } / \mathrm{g} \text { defatted meal) }\end{array}$ & 42 & 111 \\
\hline
\end{tabular}


sized by microbes in the digestive tract, e.g. as rapeseed tissue degrades, causes disintegration of glucosinolates. The products of this disintegration are glucose and aglucon (RöBbelen and THIES 1980):<smiles>[R]C(S)=NOS(=O)(=O)[O-]</smiles>

In a neutral environment aglucon releases sulphates, and isothiocyanate (trivial name mustard oil) is generated:

$$
\mathrm{R}-\mathrm{N}=\mathrm{C}=\mathrm{S}^{-}+\mathrm{HSO}_{4}
$$

In a mildly acidic environment, or when coming into contact with ferrous ion, aglucons generate nitriles and elemental sulphur:

$$
\mathrm{R}-\mathrm{C} \equiv \mathrm{N}+\mathrm{S}
$$

Isothiocyanates carrying a hydroxyl group in the $\beta$-position form spontaneously cyclic compounds, oxazolidine-2-thiones.

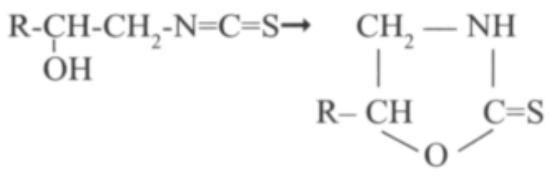

In a neutral or mildly alkaline environment isothiocyanates of indolylglucosinolate origin form thiocyanate ions (Table 11).

Table 11. Principal degradation products of the rapeseed glucosinolates (HENKEL \& MOSENTHIN 1989).

\begin{tabular}{lll}
\hline Glucosinolate & $\begin{array}{l}\text { Primary degradation } \\
\text { products }\end{array}$ & $\begin{array}{l}\text { Secundary degradation } \\
\text { products }\end{array}$ \\
\hline Progoitrin & Goitrin & $\begin{array}{l}\mathrm{pH}-7: \text { nitriles (traces) } \\
\mathrm{pH}<7: \text { nitriles and } \\
\text { isothiocyanates }\end{array}$
\end{tabular}

$\begin{array}{ll}\begin{array}{l}\text { Gluconapin } \\ \begin{array}{l}\text { Glucobras- } \\ \text { sicanapin }\end{array}\end{array} & \begin{array}{l}\text { Isothiocyanate } \\ \text { Isothiocyanate }\end{array} \\ \begin{array}{l}\text { Napoleiferin } \\ \text { Glucobrassicin }\end{array} & \begin{array}{l}\text { 5-allyl-2-thiooxazolidon } \\ \text { ph }>\text { : thiocyanate or } \\ \text { 3-hydroxymethylindole }\end{array}\end{array}$

\subsection{Analysis of glucosinolates in RSM}

Enzymatic degradation of glucosinolates by myrosinases produces substances, the identification and measuring of which can be utilized in assessing glucosinolate content. These substances include isothiocyanates, goitrin (5-vinyl-oxazolidine-2thione), nitriles and thiocyanate. The total glucosinolate content can be determined from the released glucose (McGrEGor et al. 1983).

Far more sophisticated methods for analysing glucosinolates have been developed during the last two decades, enabling their classification according to the following criteria.

Single glucosinolates can be identified by gas chromatography using tri-methylsilylised desulphoglucosinolates (TMS derivative) (UNDERHILL and KIRKLAND 1971, Thies 1976). This is also the reference method of the EEC. Reversed-phase liquid high performance chromatography has made it possible to identify all known glucosinolates either as non-degraded glucosinolates (HELBOE et al. 1980) or as desulphoglucosinolates (SANG and TRUSCOTT 1984).

The coloured complex formed by a glucosinolate and palladium ion can be measured by means of spectrophotometry - a fast and sensitive method for determining total glucosinolate content (THIES 1982, Møller et al. 1985). The X-ray fluorescence method was developed recently for determining total glucosinolate content by means of measuring the sulphur content of an organic specimen. The method is based on the close relationship of the glucosinolate and sulphur contents of the rapeseed (SCHNUG 1987). Near infrared reflectance analysis is not precise enough, not even for screening purposes (MCGREGOR 1990).

\subsection{Physiological effects of glucosinolates}

The degradation products of glucosinolates have various physiological effects, mainly affecting the thyroid. Degradation of glucosinolates is due to the release of myrosinase from degrading rapeseed tissue. The enzyme is also synthesized by intestinal 
bacteria in the gastrointestinal tract. Hence, inactivating the enzyme, e.g. by means of heating rapeseed products, will not eliminate the harmful effect of glucosinolates (MARANGOS and HiLl 1974).

Degrading glucosinolates produce isothiocyanate, which decreases thyroxine synthesis by means of reducing the amount of iodine used in the synthesis. This deficiency can be eliminated by adding iodine to the feed (ANKE 1980). Goitrin causes a more significant functional disorder by preventing the oxidation of iodide into chemically active iodine and its binding with aromatic tyrosine (GMELIN 1969, BERGNER and SCHMIDT 1972, FeNWICK and HEANEY 1983). The increased supply of iodine cannot eliminate the deficiency. Instead, the thyroid gland begins to grow, thereby increasing the production and availability of tyrosine. The goitrogenic effect can be counteracted by adding trace elements to the diet (MENZEL 1983).

Glucosinolates are very prone to affect the palatability of feeds in monogastrics. HENKEL and KALLWEIT (1989, ref. HENKEL and MOSENTHIN 1989), for example, gave chicks a feed mixture containing $20 \%$ single zero rapeseed meal (B. campestris). After a few days the birds refused to feed on it. The glucosinolate content of new double zero varieties is so low that such rapeseed meal may be given as the sole protein supplement feed $(20 \%$ to $25 \%$ of the diet) to chicks and pigs (CLASSEN et al. 1991, CAmpBell and SLOMINSKI 1991). In dairy cows glucosinolate-content affects the palatability of rapeseed meal less, and the meal of double zero varieties does not affect feed intake, not even in relatively high concentrations (EMANUELSON 1989).

In monogastrics glucosinolates induce enlargement or cirrhosis of the liver, retarded fertility, and thyroidal enlargement, as well as frailty of legs in chicks (HILL 1979). These symptoms have been significantly reduced by using double zero rapeseed meal (CAMPBELL and SLOMINSKI 1991), but its detrimental effect on the fertility of sows remains to some extent, depending on glucosinolate content (ETIENNE et al. 1991). The double zero rapeseed products have also had a negative effect on bovine fertility (EMANUELSON 1989).

\subsection{Glucosinolates in milk}

When feeds containing glucosinolates are given to cows, hydrolysis products are also secreted in the milk. VIRTANEN et al. (1959) and VIRTANEN (1963) reported that $0.05 \%$ of the goitrin (5-vinyl-oxazolidone-2-thione) present in the feed was secreted into the milk. Consequently BACHMANN et al. (1985) found that $0.1 \%$ of the goitrin in B. napus rapeseed meal was secreted into the milk.

In Finland, ARsTILA et al. (1969) reported goitrin contents ranging from 35 to $100 \mu \mathrm{g}$ per litre of milk. They assumed that the goitrin was derived from weeds of the Cruciferae family. The following year milk samples from the same area were found to be free of goitrin, presumably due to chemical weed killers used on the farms. In a Canadian study of six western and three eastern dairies the goitrin content of milk did not exceed $2 \mu \mathrm{g}$ per litre (BENNS et al. 1979). In Switzerland, BACHMANN et al. (1985) measured goitrin contents ranging from 37 to $707 \mu \mathrm{g}$ per litre, when 0.1 to $1.0 \mathrm{~kg}$ as $B$. campestris rapeseed meal was given daily. The extracted rapeseed meal contained $46 \mu \mathrm{M}$ goitrin per gram, with a total glucosinolate-content of $77 \mu \mathrm{g}$ per gram. In Finland the goitrin content of dairy milk was measured in 1983 from 224 samples from various regions in the country. The goitrin content exceeded the minimum discernible level of $2 \mu \mathrm{g}$ per litre in only 19 samples, averaging $6.4 \mu \mathrm{g}$ goitrin per litre in these samples (range 2 to $31 \mu \mathrm{g} / \mathrm{l}$ ) (RAURAMAa 1983).

The role of milk in endemic goitre has been the subject of much discussion. Peltola (1960) gave rats milk collected "from a moderately severe goitre endemic area" (Orimattila, Finland) and milk from "a non-goitrous district" (Porvoo, Finland). The milk from the "goitrous area" induced enlargement of the thyroid gland, which could not be prevented by supplemental iodine. This result could not, however, be obtained by VIRTANEN (1963).

Krusius and Peltola (1966) found that $0.1 \mu \mathrm{g} / \mathrm{d}$ goitrin induced nearly significant, and $0.5 \mu \mathrm{g} / \mathrm{d}$ significant, thyroid growth in rats. That means a ratio of 0.5 to $2.3 \mu \mathrm{g} / \mathrm{d} / \mathrm{kg}$ metabolic live weight and 12 
to $59 \mu \mathrm{g} / \mathrm{d}$ per $75 \mathrm{~kg}$. IVARSSON and NILSSON (1973) gave rats milk from cows that had been feeding on concentrates containing none, $4.2 \%$ or $8.1 \%$ RSM $(69 \mu \mathrm{M}$ isothiocyanate and $81 \mu \mathrm{M}$ goitrin per $\mathrm{g}$ of DM). In rats thyromegaly could be prevented by increasing the intake of iodine, but the combined effect of goitrin and other goitrogenic substances could not be excluded. There is relatively little information about the quantity at which goitrin becomes harmful to man. Arstila et al. (1969) stated that $200 \mu \mathrm{g} / \mathrm{d}$ will suffice to inhibit the normal accumulation of radioiodine in the thyroid gland, and this dose may also induce enlargement of the thyroid gland.

\subsubsection{Sinapine}

Sinapine is a choline ester of sinapine acid (3,5dimethoxy-4-hydroxycinnamic acid). Sinapine is a cation, and in the rapeseed it is combined with the glucosinolate sinalbin (p-hydroxybenzylglucosinolate), thus substituting potassium. The sinapine content of rapeseed varies between 0.78 and 1.33 per cent (APPELQVIST 1972), being lower in B. campestris than in B. napus (MUELLER et al. 1978). In an alkaline environment sinapine is hydrolysed to sinapic acid and choline. Contrary to the free choline present in feeds, or choline chloride or hydrolyzed sinapine, which are absorbed in the small intestine, bound choline is not absorbed in that manner (GoH et al. 1979). In the large intestine the intestinal bacteria converted sinapine to trimethylamine (HoBson-FroHock et al. 1973, MARCH and MACMillan 1978), which, when absorbed, is converted to trimethyloxide by the liver and kidneys, and secreted. Certain species of poultry (those laying brown eggs) have a genetic defect, resulting in an insufficient level of the TMA-oxydase activity for all the trimethylamine to be degraded, the remaining trimethylamine being deposited in the egg, affecting its flavour (PEARSON et al. 1979). TMA-oxydase synthesis may also be adversely affected by free goitrin and tannin (FENWICK et al. 1981, GoH et al. 1985). Similarly, a fishy smell has been observed in milk (ANDERSEN 1985).

\subsubsection{Phytic acid}

THOMPSON (1990) has produced a comprehensive review of phytic acid. It is a myo-inositol (1,2,3,4,5,6-hexakis-dihydrogen phosphate) by structure. Phytic acid acts as the primary reservoir of phosphorus, binding between 60 and 90 per cent of the phosphorus present in the rapeseed. Phytic acid also binds cations, and protects the plant from oxidative defects and molding during storage by binding zinc. Phytic acid is normally present in rapeseed as salts of $\mathrm{Ca}, \mathrm{Mg}$ and $\mathrm{K}$. The phytic acid content of extracted B. campestris or B. napus rapeseed meal varies between $3.7 \%$ and $4.8 \%$, averaging $4.4 \%$ of the defatted meal (ANJOU et al. 1977).

Phytic acid has a detrimental effect on the utilization of zinc, although the high fibre content is also inversely related to the utilization of minerals (Nwokolo and BragG 1977). On the other hand, SuMMERS and LEESON (1985) found no difference between soybean or rapeseed meal in the utilization of minerals by chickens on normal diets. Phytic acids also bind proteins, but no effect on in vivo digestibility has been demonstrated. As a nutrient phytic acid is believed to reduce the incidence of cancer of the colon in man.

\subsubsection{Tannins}

KozLOWSKA et al. (1990) studied the tannins present in rapeseed. Tannins are complex phenolic compounds with a molecular weight ranging from 500 to 3000 . The tannin content of extracted rapeseed meal is 2 to 3 per cent (FENWICK and HogGan 1976). Containing, for instance, tannic acid, tannins are bitter in taste and therefore obviously have, together with glucosinolates, a detrimental effect on palatability. The high tannin content of certain varieties of sorghum reduces the utilization of protein in poultry, but a similar combined effect of tannin and protein has not been observed in the rapeseed (KoZLOWSKA et al. 1990). 


\subsection{Rapeseed meal as a protein supplement for dairy cows}

The use of rapeseed meal in dairy cattle was reviewed e.g. by Tномке (1981) and Hill (1991). In the past the use of rapeseed meal or cakes as a protein supplement was limited due to the high glucosinolate content of single zero varieties of rapeseed. The addition of between 0.5 and $1.5 \mathrm{~kg}$ of RSM or cakes to the diet of dairy cows had no noticeable effect on milk production, compared to other protein supplements (BÜNGER et al. 1940, POIJÄRVI 1944, JARL 1951, NORDFELDT 1958, ASPLUND and MCELROY 1961, LindELL and KNUTSSON 1976, LINDELL 1976, LAARVELD and CHRISTENSEN 1976, SYrJÄLÄ-Qvist et al. 1982). Reduced palatability (NORDFELDT 1958) or milk yield was observed in some experiments, especially at high RSM levels (20 - 30\% in the concentrate) (ASPLUND and MCELroy 1961, Ingalls et al. 1968, WALDERN 1973).

Low glucosinolate double zero rapeseed cultivars have made RSM equal to other vegetable supplements in the diet of dairy cows (INGALLS and Sharma 1975, Sharma et al. 1977, Papas et al. 1978, SanCHEZ and Claypool 1983, MurPhy et al. 1985, VinCENT and HiLl 1988, VinCENT et al. 1990).

Long term studies have produced some evidence of lowered fertility due to 0-RSM (LinDELL 1976, LiNDELL and KNUTSSON 1976), and with 00-RSM on primiparous cows (AHLIN et al. 1985, EMANUELSON 1989, EMANUELSON et al. 1991). This negative effect on primiparous cows was confounded with the type of rapeseed, as the glucosinolate content was highest in the beginning of the experiment, being reduced to one half in the course of the threeyear experiment (EMANUELSON 1989).

\subsection{New systems for evaluating feed protein in dairy cattle}

The protein evaluation of ruminant feeds has traditionally been based on digestible crude protein. During the last ten years many new systems have been reported, all taking into account the protein metabolism of both the rumen and the animal. ALDERMAN (1987) has listed six new systems for evaluating feed protein:

i. The British RDP/UDP system (rumen degraded and rumen undegraded protein) of RoY et al. (1977), subsequently published (1980) and revised by ARC (1984), which describes feeds in terms of truly absorbed amino nitrogen (TAAN). It is to be converted to metabolizable protein for practical purposes (MP=6.25 TAAN) (WEBSTER 1987, 1992),

ii. The French PDI system (protein digested in the intestine) (INRA 1978, VÉRITÉ et al. 1979, VÉRITÉ and PeYraud 1989).

iii. The Swiss API (absorbable protein in the intestine), developed from the PDI system (BICKEL and LANDIS 1987).

iv. The German system of measuring the duodenal flow of crude protein (Ausschuss für Bedarfsnormen 1986, ref. AldermanN 1987, RoHR 1987). PiATKowski et al. (1990) and Voigt and PiatKowSKI (1991) have corrected the efficiency of microbial protein synthesis by taking into account the negative effect of the proportion of UDP in the feed protein.

v. The Nordic ${ }^{1}$ AAT-PBV system (absorbable amino acids in the duodenum; protein balance in the rumen) (MADSEN 1985).

vi. The American AP system (absorbed protein) (NRC 1986).

\subsubsection{AAT-PBV feed protein evaluation system}

The AAT measures intraduodenally true absorbable amino acids, which originate in the microbial protein synthesized in the rumen and the undegraded feed protein (UDP) in the rumen. PBV is the balance between rumen degraded protein (RDP) and the protein requirement of microbes in the rumen (MAdSEN 1985, Hvelplund and MAdSEN 1990). The system for calculating the AAT-PBV values for feeds is presented in Appendix 1. 


\subsubsection{Effective degradation of feed protein}

Degradation of feed protein is measured using the in sacco method (MEHREZ and ØRSKOV 1978), bearing in mind the recommendations of the CECEAAP workshop (OLDHAM 1987) and the Nordic Working Group (MADSEN 1985, LindBerG 1985, HVELPLUND 1990). The effective protein degradation (EPD) is calculated according to a system devised either by ØRSKOV and MCDONALD (1979), MCDonald (1981) or Kristensen et al. (1982). The method reported by ØRSKOV and MCDONALD (1979) is presented in Appendix 1.

The correct EPD value, determined with the in sacco method, is always only an estimate, as it is affected by many factors in the feed and the rumen, e.g., microbial nitrogen contamination of feed residues in incubated samples, loss of particles from the bag, lower microbial density in the bag than outside it in the rumen, and the value used to calculate the rate of outflow from the rumen. The in sacco method is not suitable for feeds containing highly soluble protein, if all soluble protein is not degraded in the rumen. The in vitro method, whereby inhibitors are used to stop the fermentation, may be useful, but it requires automated laboratory equipment (BRODERICK 1987, BRODERICK and Clayton 1992).

\subsubsection{Microbial nitrogen contamination of feed residues in bag}

Feed residues in the bag after incubation include contaminated microbes, and the degradation values obtained are lower than true values (VARVIKKO and LINDBERG 1985, VARVIKKO 1986). In Denmark a stomacher machine was used for washing bags to loosen microbes from the feed residue (MERRY and MCAllan 1983, Hvelplund and Møller 1987). In France, Michalet-DoREAU and OUlD-BAH (1989) developed a correction formula, whereby microbial nitrogen contamination is regressed against the nitrogen and NDF contents of the sample. On the other hand, after determining the nitrogen bound by NDF LINDBERG (1988) calculated that the EPD of grass is constant and independent of the growth stage or level of nitrogen fertilization.

\subsubsection{Small particle loss from the bag}

In finely ground samples the loss of nitrogen in small particles is a problem, even a severe one, especially severe in oats, ranging from $30 \%$ to $70 \%$ of the total protein content. WEISBJERG et al. (1990) designed a correction formula for degradation values adjusted for particle loss. Without any correction for the loss of $\mathrm{N}$ in particles from the bag, this part will have to be included into fraction a, which is protein degraded rapidly in the rumen. In such feeds the EPD value will be excessively high and the AAT value excessively low. For a $60 \%$ loss of oat particles the AAT value will be ca. $30 \%$ too low. For oil meals the problem is less severe, with particle loss seldom exceeding $15 \%$.

Making corrections for particle loss is not devoid of problems, the underlying assumption being that protein in small particles is degraded at the same rate than the protein remaining in the bag, which may not always be true.

The pore size of the bag fabric cannot be reduced, because intrusion of bacteria into the bag would be reduced. According to MEYER and MACKIE (1986) the optimal pore size was $53 \mu \mathrm{m}$, and even then the concentration of microbes was only $60 \%$ to $80 \%$ of that outside bag in the rumen. With cellulolytic bacteria the effect was even greater. HUHTANEN and KHALILI (1992) reached the same conclusion after measuring enzyme activity in the bag and in the particles present in the rumen. Much higher carboxymethylcellulase and xylanase activity was measured in particles in the free rumen contents than in feed particles within the nylon bag.

In some feeds protein is fully soluble, and then the EPD value is $100 \%$ and UDP $0 \%$. This need not be correct, because some of the peptides have been observed to flow the duodenum (CHEN et al. 1987).

\subsubsection{Fractional outflow rate from the rumen}

In the Nordic system the outflow rate of particles 
from the rumen is constant, $\mathrm{k}=0.08$ (HVELPLUND and MADSEN 1990). In France the k-value is also constant, i.e. 0.06 for all feeds, but in Britain it varies from 0.02 to 0.08 depending on the feeding level (VÉrité and PeYraud 1989, ARC 1984). The outflow rate for particles of concentrate has usually been reported to be higher than that of roughage particles (ColuCCl et al. 1982, ColuCCI et al. 1990). At maintenance level the outflow rate of particles has been measured as 3 to 4 per cent, rising to 6 to 9 per cent at higher feeding levels (GANeV et al. 1979, LindBerg 1982, Elinam and ØrSKov 1984, ColuCCI et al. 1982, HadjIPANAYIотоu et al. 1988, ColucCI et al. 1990).

Markers, for instance straw or protein feed treated with neutral detergent and mortanded with chromium, were used in the studies quoted. Such treatment removes the soluble fraction of the marker carrier, and it behaves as indigestible feed particles. The outflow rate of indigestible NDF has been found to be much higher than that of digestible NDF (TAMminga et al. 1989, HuHTANEN and KHALILI 1991). This can be confirmed by means of the rumen evacuation technique, when the average rumen content can be accurately determined, and the ratio between daily faecal output of cell wall components and those contained by the rumen gives an indication of the average rate of passage of cell wall components from the rumen (ROBINSON et al. 1987, TAMminga et al. 1989).

The nitrogen flowing into the duodenum comprises ammonium nitrogen, with an outflow rate similar to that of the liquid phase, undegraded feed nitrogen with an outflow rate similar to that of NDF, and microbial nitrogen, which in the liquid phase is partly free and partly attached to feed particles. The outflow rate of nitrogen is between that of the liquid phase and that of the solid phase according to TAMmINGA et al. (1989). They reported an increase in the outflow rate of total-N from 0.038 to 0.060 when the feed intake of dairy cows increased from 6.0 to $24.0 \mathrm{~kg}$ per day. The average outflow rate of NDF, which is close to that of undegraded feed protein, varied from 0.019 to 0.025 in dairy cows in two trials. HuHTANEN and
KHALILI (1992) reported outflow rates of NDF ranging from 0.016 to 0.017 in cattle on a diet of grass silage.

The in sacco method also gives too low degradation values for the potential degradable fraction in the bag (TAmminga et al. 1989), probably due to lower microbial enzyme activity in the bag than outside it (MeYer and MACKIE 1986, HuHTANEN and KHALILI 1992). This, together with the overestimated outflow rate for UDP, leads to underestimates of the effective degradation of feed protein in the rumen.

\subsubsection{Efficiency of microbial protein synthesis}

The most important factor for the new protein estimation systems is estimating the synthesizing efficiency of microbial protein in the rumen, as microbial protein accounts for $40 \%$ to $80 \%$ of the total amino acid nitrogen (AAN) entering the small intestine (SMITH 1975, SNIFFEN and RoBINSON 1987). All systems are based on constant factors related to the feed energy released in the rumen, but they differ in terms of how the energy released from the feed for use by microbes is estimated. The AAT-PBV system relates the energy released in the rumen to the total digestible carbohydrate content (DCHO), the British system relates it to the fermentable organic matter in the rumen (FOM), or total ME, whereas the French system relates it to the total digestible organic matter content less the sum of the ether extract, bag UDP and fermentation products.

The experimental data shows great variations in the efficiency of microbial protein synthesis between diets. For instance, the AAT-PBV system is based on a value of 20 grams of microbial aminonitrogen per kilogram of DCHO. The figure was arrived at in an experiment where the microbial efficiency on a concentrate-rich diet was $60 \%$ lower than on a roughage-rich diet (20 g vs. $32 \mathrm{~g}$ AAN/kg DCHO) (HVELPLUND and MADSEN 1985). The flow of microbial nitrogen was measured from the difference between the total NAN content and the undegraded feed nitrogen, measured by the in 
sacco method. The DAPA (2,6-diaminopimelic acid) system was also used to measure the flow of microbial nitrogen, and this gave approximately 10 per cent higher efficiency values for protein synthesis with concentrate-rich diets compared to the difference method (HVELPLUND and MADSEN 1985).

TAMMINGA (1981) measured an average efficiency value of microbial protein synthesis of $32 \mathrm{~N}$ grams per kilogram of fermentable carbohydrates in the rumen (FOM), with a variation of 25 to 38 grams. HAGEMEISTER et al. 1980 reported value of $35 \mathrm{~g}$ microbial $\mathrm{N}$ synthesis per kg FOM. In a review by ARC (1984) the microbial efficiency was 26.8 grams microbial N/ kg fermented organic matter (FOM) with a grass silage diet, whereas the corresponding figure for silage diet with concentrate was 36 grams. The value of 32 grams was taken as a constant for this system.

Microbes in the rumen either exist free in liquid, or are attached to small feed particles, most of the microbial mass being of a particle-associated population and microorganisms associated with protozoa (Oluboвokun et al. 1988). It is therefore important to know how the markers behave with microbes in different pools. Protozoa contain no diaminopimelic acid, and the microbes in particles contain less DAPA and ribonucleic acid (RNA) than the microbes in the liquid phase (MERRY and McAllan 1983, Craig et al. 1987). There is no difference in the purin content between particle and liquid associated microbes, but the ratio of purin over total nitrogen is lower in protozoa than in bacteria (FIRKINS et al. 1987a). The use of these markers will result in excessively low microbial protein flow rates. FIRKINS (1987b) observed a 10\% lower nitrogen flow rate in duodenal bacteria using purins as markers, compared to ${ }^{15} \mathrm{~N}$.

Increasing the feeding level will also increase the efficiency of microbial protein synthesis. This effect is minimal in growing cattle (FIRKINS 1987b, GLENN et al. 1989, ROOKE et al. 1992), but in dairy cattle the effect of feeding level is really significant. Increasing the feed intake from $6.0 \mathrm{~kg}$ to $17.4 \mathrm{~kg}$ organic matter $(\mathrm{OM})$ per day resulted in an increase in bacterial nitrogen yield at a growing rate 17.4-34.8 g bacterial $\mathrm{N} / \mathrm{kg}$ OM apparently digested in the rumen (OMADR) (ROBINSON et al. 1985). The authors suggested that an increase in the quantity of fiber escaping the rumen, associated with increased feed intake, stimulates bacterial escape by washing out particles that are at an earlier stage of digestion with more bacteria attached. As the retention time of particles in the rumen decreases, the number of attached bacteria may increase rapidly. This may also explain the high efficiency values of 40 to $60 \mathrm{~g}$ microbial N/kg OMADR in dairy cows with a high feed intake (Rode and SATTER 1988, MCCARTHY et al. 1989, KLUSMEYER et al. 1990, CAMERON et al. 1991).

Fermented feeds, such as grass silage, contain fermentation products, that are not utilized as energy by microbes. Only about $25 \%$ of the energy derived from lactic acid is utilized by microbes (Demeyer and VAN Nevel 1979). On the other hand, CHAMBerlain (1987) observed that ca. 50\% of the energy released by fermenting proteins is utilized by microbes. The new systems do not take into account these factors. NousiaINEN (1992) presented results on how this DCHO-correction affects the EPD and AAT values of silage. He also calculated the true indigestible duodenal protein as a function of the crude protein content of silage, and used a double pool model (ARC 1984). AATvalues, calculated with the system, increased from 71 to $83 \mathrm{~g} / \mathrm{kg}$ silage DM, when crude fibre content increased from $26 \%$ to $32 \%$ of DM. The corrected AAT-values increased less, from 72 to $78 \mathrm{~g} / \mathrm{kg}$ DM, respectively.

The results reported by JAAKKOLA et al. (1991) showed that microbial nitrogen yield decreased when the quantity of fermentation products increased. However, compared to silage, the microbial yield was lower with hay (JAAKKOLA and HUHTANEN 1990). There are inexplicable variations in the efficiency of microbial protein synthesis. For instance, JAAKKOLA et al. (1991) measured a mean efficiency of $39 \mathrm{~g} \mathrm{MN} / \mathrm{kg}$ OMADR in growing steers. JAAKKOLA and HuHTANEN (1992a) used growing steers again, obtaining a mean efficiency of only $15 \mathrm{~g} \mathrm{MN} / \mathrm{kg}$ OMADR. In both trials the 
same methods and markers were used, and the feed was in both cases direct cut grass silage.

These results showed that many related factors affecting microbial synthesis in the rumen remain unexplained.

\subsubsection{Amino acid content and digestibility of duodenal proteins}

The proteins flowing through the duodenum consist of microbial, undegraded feed protein and endogenous protein. According to many published reports the proportion of amino acids in microbial protein is ca. $80 \%$ (ref. HVELPLUND and MADSEN 1990 ), and this value has been adopted by several systems (ARC 1980, NRC 1985, VÉrITÉ and PEYRAUD 1989). In the AAT-PBV system the proportion of amino acid in the microbial protein is lower, being $70 \%$, based on the studies of HVELPLUND and Møller (1980). Later Hvelplund (1986) estimated the proportion of amino acids to be between 0.62 and 0.72 in 49 isolated bacterial samples, and he still considers $70 \%$ to be the correct value. That value is also used in Germany (ROHR 1987).

The proportion of amino acids in undegraded protein is estimated as $100 \%$ by many systems (ARC 1980, NRC 1985, Vérité and PeYraud 1989). The AAT-PBV system uses estimates of $85 \%$ for concentrates and $65 \%$ for roughage. This is consistent with the data in eighteen published papers collected by HVELPLUND (1986).

The digestibility of the duodenal amino acids varies in different systems: $80 \%$ (NRC 1985), $85 \%$ (ARC 1984) and 90\% (RoHR 1987). In the French system digestibility of microbial amino acid protein is $80 \%$, and that of undegraded feed protein varies from $55 \%$ to $90 \%$ (VÉrIté and PEYRAud 1989). In the AAT-PBV system the rate of true digestibility is $85 \%$ for amino acids of microbial origin and $82 \%$ for those of feed origin (MADSEN 1985). The true digestibility of undegraded feed protein can be determined by using the duodenal bag (or mobile bag) technique, whereby feed samples incubated in the rumen and abomasum are passed through the small intestine in small nylon bags (Hvelplund 1985, RAE and Smithard 1985, Voigt et al. 1985, VARViKKo and Vanhatalo 1988, Vérité and PeYraud 1989, Hvelplund and MADSEN 1990). If TU means truly indigestible feed protein, the digestibility of UDP equals (UDPTU)/UDP (VÉrité and PEYRAud 1989, HvelPLUND and MADSEN 1990). This method was adopted by the AAT-PBV system (HvELPLUND 1990). TU can be determined from an intact feed sample using the mobile bag technique for concentrates. Preincubation in the rumen is necessary for forage, as it increases digestion of feed protein in the intestines (HVELPLUND et al. 1992).

\subsubsection{Utilization efficiency of amino acids for lactation in dairy cows}

The utilization efficiency of amino acids is affected by the potential performance of the animal, the quantity of energy and AA supplied, and the balance of AA in the feed (RULQUIN and JOURNET 1987, Oldham 1987a). The theoretical maximum rate of $82 \%$ for efficiency would apply only when an ideal mix of AA is supplied, and the AA input places the first limit on performance (OLDHAM 1987a). The optimal values for efficiency obtained at normal feeding levels of energy and protein are, however, ca. 20\% lower, (RULQUIN and JOURNET 1987).

The British protein evaluation system has adopted the value of 0.80 for the utilization efficiency of truly absorbed amino acids (ARC 1984), which may be too high for practical applications (Oldham 1987b). Kaufmann (1977) estimated the utilization rate to be $70 \%$, and PIATKOWSKI et al.(1990) suggested the same. The French system adopted the value of $64 \%$ for utilization efficiency of PDI in lactating cows, as values ranging from 0.58 to 0.69 were obtained in 24 trials (VÉRITÉ and Peyraud 1989). The AAT-PBV system adopted a variable rate of utilization efficiency ranging from 0.75 to 0.80 (MADSEN 1985). In a practical feeding trial a lower efficiency rate was obtained, and there have been great variations within a single year and on one site (KRISTENSEN et al. 1985, Oldham 
1987a).

The protein requirement for milk production can be calculated by dividing the milk protein yield by the efficiency of protein utilization. In the French system the protein requirement is $\mathbf{4 8} \mathrm{g}$ of protein digested in the intestine per kilogram of milk (31/0.64). The recommendation for AAT requirement in the Nordic system is $37-42 \mathrm{~g} \mathrm{AAT} / \mathrm{kg} \mathrm{ECM}$ (HVELPLUND 1990) corresponding an efficiency of 0.74-0.84.

\section{Objectives of the study}

In Finland milk production is mainly based on forage and grain feeding. Unwilted grass silage usually accounts for one third of the total net energy intake (fattening feed units) in recorded herds. Grain is supplemented by protein concentrates, soybean meal (SBM) and rapeseed meal being the most important ones. Rapeseed (mainly of turnip rape, Brassica campestris L.) is the only important oilseed plant that thrives in Finland. The present study examined how milk yield and quality is affected by various quantities of rapeseed meal in the diet, and the different treatments of rapeseed.
The feed protein evaluation in dairy cattle, which in Finland is still based on digestible crude protein, is (or will be) based on the AAT-PBV system in neighbouring Scandinavia. The second objective of this study was to compare the DCP and AAT-PBV systems using data of Finnish milk production trials as material, from which various parameters describing the utilization of feed protein were calculated.

\section{Material and methods}

The experimental data of experiments of 1 to 5 , including the materials and methods, is presented here. The data concerning experiments 6 to 9 has been reported elsewhere (See Table 12). The data of experiments 1 to 7 included feed intake and milk production with calculated DCP and AAT intakes, whereas the AAT intake was excluded in experiments 8 and 9 (RSM vs. control).

In all experiments unwilted grass silage was given ad libitum (in one experiment silage or hay cut at the same growth stage was given). The quantity of concentrate was fixed at $6-8.5 \mathrm{~kg}$ per day, except for two trials, in which the concentrate was given according to milk yield (Exp. 2 and 6).

Table 12. List of the experiments, of which the data was used in this study.

\begin{tabular}{|c|c|c|c|c|c|c|c|}
\hline \multirow{2}{*}{$\begin{array}{l}\text { No. of } \\
\text { Exp. } \\
1\end{array}$} & \multirow{2}{*}{$\begin{array}{l}\text { Research } \\
\text { Station }\end{array}$} & \multirow{2}{*}{$\begin{array}{l}\text { Years } \\
1983-84\end{array}$} & \multicolumn{2}{|c|}{$\begin{array}{l}\text { Number of } \\
\text { Cows Diets }\end{array}$} & ts Experimental design & Treatments & Source \\
\hline & & & 24 & $4 \mathrm{C}$ & Continuous, comparison period of 11 weeks & RSM levels, treame & \\
\hline 2 & “ & $1984-85$ & 24 & $2 \mathrm{C}$ & Continuous, comparison period of 12 weeks & Treatment of RSM & 1 \\
\hline 3 & “ & $1987-88$ & 10 & $5 \mathrm{~T}$ & Two 5x5 Latin squares, 25-day's periods & RSM levels, treatme & SM \\
\hline $4 a$ & Maaninka ${ }^{4}$ & $1987-88$ & 8 & $4 \mathrm{~T}$ & Two 4x4 Latin squares, 4-week's period & RSM-levels, silage & 2,3 \\
\hline $4 \mathrm{~b}$ & Maaninka ${ }^{4)}$ & $1987-88$ & 8 & $4 \mathrm{~T}$ & Two $4 \times 4$ Latin squares, 4-week's period & RSM-levels, hay & 2,3 \\
\hline 5 & Viikki $^{1)}$ & 1989-90 & 14 & $7 \mathrm{C}$ & Cyclic change-over, 4 periods of 4 weeks & RSM-and SBM-lev & reatments \\
\hline $\begin{array}{l}6 \\
4\end{array}$ & Jokioinen ${ }^{3)}$ & $1986-87$ & 30 & $6 \mathrm{C}$ & Continuous, comparison period of 8 weeks & RSM-levels, silage & tage \\
\hline 7 & Viikki' ${ }^{1)}$ & $1987-88$ & 12 & $6 \mathrm{C}$ & Cyclic change-over, 4 periods of 4 weeks & Treatment of RSM & 5 \\
\hline 8 & Suitia ${ }^{2)}$ & $1987-88$ & 20 & 44 & $4 \times 4$ Latin square, 4 -week period & RSM-level & 6 \\
\hline 9 & Viikki" & $1990-91$ & 16 & $8 \mathrm{C}$ & Cyclic change-over, 4 periods of 4 weeks & RSM-level & 7 \\
\hline
\end{tabular}

Research station:

1) University of Helsinki, Viikki Experimental Farm; ${ }^{2)}$ University of Helsinki, Suitia Experimental Farm; ${ }^{3)}$ Agricultural Research Center of Finland, Department of Animal Production; ${ }^{4)}$ Agricultural Research Center of Finland, North Savo Experimental Station

Sources:

1) TUORI \& SYrJĀLĀ-Qvist (1987); 2) TUORI \& SYrJĀLĀ-Qvist (1988); 3) SUVITIE \& RINNE (1988); 4) HeIKKILĀ et al. (1989); 5) HUHTANEN (1991): 2 experimental groups; 6) HUHTANEN et al. (1991): 2 experimental groups; 7) HuHTANEN (1992, unpublished) 


\subsection{Experiment 1}

\subsubsection{Animals and management}

Twenty-four Finnish Ayrshire cows calving in the autumn were used in a continuous milk production trial. Sixteen cows were multiparous and eight primiparous. The cows were housed in a cowshed with individual stalls. Feed was given individually twice a day, and orts were collected and weighed once a day. The feed was accessible for seven hours daily. Unwilted grass silage was given in sufficient quantities to ensure orts averaging $5 \%$ to $10 \%$ of the mass of the silage, with intakes measured and recorded. Concentrate was offered at a fixed rate: 7 $\mathrm{kg}$ per day during lactation weeks 1 to 14 , and 3.5 $\mathrm{kg}$ per day during weeks 15 to 28 . The daily ration of hay was $2 \mathrm{~kg}$. The cows were milked twice daily commencing at 6 a.m. and 4 p.m. The milk was weighed and the figures were recorded with a Truetest milkometer five days a week. The cows were weighed every second week. This report includes feed intake and production data for lactation weeks 4 to 14 only.

\subsubsection{Experimental design and treatments}

A randomized block design with four treatments was used. The cows were taken to the trial a few days after calving, being assigned to six blocks according to calving date and age, and then assigned within each block randomly to four treatments. The experiment covered lactation weeks 1 to 28 , with the exception of the last blocks, which ended at about lactation week 20. One heifer died during the trial in her 19th week of lactation. The treatments consisted of diets including three different protein ratios in the concentrate and one group with treated protein. The control diet consisted of a concentrate including only a grain mixture, whereas the other diets consisted of a concentrate with $23 \%$ or $37 \%$ protein supplement of which $88 \%$ was rapeseed meal. The smaller protein supplement was either untreated or heat-treated.

\subsubsection{Feeds}

The feeds used in the experiment were direct cut silage, mainly of the first grass crop of the season, containing timothy, meadow fescue and red clover (ratio 60:20:20). The herbage was harvested with a precision harvester, and 5 litres of formic acid per tonne of silage was applied at harvesting. The silage was stored in concrete tower silos. The hay consisted mainly of timothy.

A pelleted protein supplement consisting of $88 \%$ either untreated turnip rapeseed meal (Brassica campestris L., var. "Span" and "Torch", both single low varieties), or dry heat-treated rapeseed meal (Brassica napus L.), 8\% dried brewers grain and $4 \%$ molasses. The control group was given the same amount of molasses with grain as a supplement. The dry heat-treatment was performed by Öljynpuristamo Oy, Helsinki.

The total glucosinolate content of untreated RSM was $43 \mu \mathrm{mol} / \mathrm{g}$ of fat-free matter, and of treated RSM $8 \mu \mathrm{mol} / \mathrm{g}$ fat-free matter, measured by gasliquid-gas chromatography (GLC). The grain mixture of oat and barley (ratio 1:1) was preserved with propionic acid and rolled before feeding. The cows were also given daily 250 grams of a mineral mixture containing $17.5 \% \mathrm{Ca}, 7.8 \% \mathrm{P}$ and $6.0 \%$ $\mathrm{Mg}$.

\subsubsection{Sampling and analytical methods}

The silage samples taken weekly were dried at $103^{\circ} \mathrm{C}$ for 24 hours to determine their dry matter contents. The dry matter content was corrected for volatile losses by adding $41 \%$ of lactic acid, $89 \%$ of volatile fatty acids (VFA) and $100 \%$ of ammonia (PORTER et al. 1984). The samples taken for establishing the fermentation pattern of silage, and for the in sacco determination, were kept frozen until analysed. For analysis the samples were pooled to seven batches according to the date and origin of the silage. Samples were taken from every new batch of hay and grain brought into the barn. For proximate (Weende) analysis samples were dried in a vacuum at $50^{\circ} \mathrm{C}$ and then milled through a $1 \mathrm{~mm}$ screen. The 
in vitro digestibility of silage and hay was measured (TILley and Terry 1963), and standard procedures were followed in the proximate analysis. Samples of fresh silage were analysed for reducing sugars (SOMOGYI 1945, with modifications of SALO 1965), lactic acid (BARKER and SUMMERSON 1941), volatile fatty acids (HUIDA 1973), ammonia nitrogen (McCullough 1967), and for total and water soluble Kjeldahl nitrogen. Degradation of protein was determined in a sheep in sacco (MEHREZ and ØRSKOV 1977, SETÄLÄ 1983). The incubation times of concentrates were 2, 5, 8 and 24 hours, and an additional 48 hours for silage and hay. The sheep was given a mixture of silage, hay and barley (ratio 45:45:10 on DM basis). The glucosinolate content of RSM was measured at the Department of General Chemistry of the University of Helsinki, using the GLC method described by HEANEY and FENWICK (1980), with minor modifications as per HASE et al. (1988). The digestibility values for concentrate feeds in calculating feed values were derived from feed tables (SALO et al. 1982). Energy corrected milk was calculated according to SJAUNJA et al. (1990).

Milk samples were taken once a week (evening and morning) and analysed at the laboratory of Valio Finnish Co-operative Dairies' Association for fat and protein with the infra red (IR) technique on a Milko-Scan 300 (Foss Electric, Denmark). Milk urea was measured using the enzymatic colorimetric method with a KONE CD analyzer (RAJAMÄKI and RAURAMAA 1984). Goitrin content (L-5vinyloxazolidine-2-thione) was measured at the laboratory of Valio using high performance liquid chromatography (HPLC) (BENNS et al. 1979) and a reverse-phase column (RAURAMAA 1983).

\subsubsection{Statistical analysis}

A fixed model of least squares variance analysis was used to calculate the corrected means for intake and production data (HARVEY 1966):

$\mathrm{y}_{\mathrm{ijk}}=\mu+$ diet $_{\mathrm{i}}+$ block $_{\mathrm{j}}+\varepsilon_{\mathrm{ijk}}$

The WSYS statistical software developed by VILVA (1989) was used in all calculations.

\subsection{Experiment 2}

\subsubsection{Animals and management}

Twenty-four autumn-calving Finnish Ayrshire cows, twelve primiparous and twelve multiparous, were used in a continuous milk production trial. A standardization period of 4 weeks preceded the test period of twelve weeks. At the start of the trial the time since calving averaged 38 days. Concentrate was offered at the rate of $0.3 \mathrm{~kg}$ per kilogram of fatcorrected milk. Unwilted grass silage ad libitum and about $2 \mathrm{~kg}$ hay were also available daily. The cows were housed as in experiment 1 , except that milk yield was measured with a True-Test milkometer every day. They were weighed once a fortnight, and twice at the beginning and end of period.

\subsubsection{Experimental design and treatments}

A $2 \times 2$ factorial randomized block design was used, the factors being the treatment of RSM and bovine primiparity vs. multiparity. First the cows were assigned into five groups on the basis of calving date and age, after which they were randomly assigned to one of two treatments consisting of different diets. The control diet consisted of a grain mixture including $17 \%$ turnip rapeseed meal and the test diet of the same amount of heat-moisture treated turnip rapeseed meal.

\subsubsection{Feeds}

Direct cut silage was harvested partly with a flail and partly with a precision harvester into a tower silo, and 5 litres of formic acid per tonne was added to it. The grass was predominantly timothy, including some meadow fescue and red clover. A mixture of rolled barley and oat (ratio 1:1) was used as grain. The oat was dried, and the barley was preserved with propionic acid. The RSM was of a single zero variety (Emma). The heat treatment of RSM ("'Öpex-treatment at the plant of Öljynpuristamo Oy) was carried out in a pressure chamber in elevated temperature and moisture. The total glucosino- 
late content was $49 \mu$ moles in untreated, and 15 $\mu$ moles in treated RSM, as measured with the GLC method by the Department of General Chemistry, University of Helsinki.

\subsubsection{Sampling and analytical methods}

Feed and milk samples were taken as described in experiment 1 . For analysis the weekly silage and hay samples were pooled over four-week periods. Every two samples of concentrate were pooled for analysis. The feed was analysed, and the in sacco degradable protein was determined as in experiment 1 . The in sacco determinations were carried out in a sheep feeding on silage, hay, barley and RSM (dry matter ratio 40:40:10:10).

\subsubsection{Statistical analysis}

The milk production data was analysed in terms of covariance, using the least squares variance analysis (HARVEY 1966):

$\mathrm{y}_{\mathrm{ijk}}=\alpha+\mathrm{T}_{\mathrm{i}}+\mathrm{A}_{\mathrm{j}}+\mathrm{b}_{1}{ }^{*} \mathrm{P}_{\mathrm{ijk}}+\varepsilon_{\mathrm{ijk}}$

where $T_{i}$ is treatment, $A_{j}=$ primiparity vs. multiparity of the cow; and $\mathrm{P}_{\mathrm{ijk}}$ is the production rate of the cow during the standardization period. The effects of the block and interaction between age and treatment were not significant, and they were excluded from the model. WSYS statistical software was used for the calculations (VILVA 1989). Feed intake was analysed without covariance. The least squares corrected means were calculated from production data (Appendix 3), but uncorrected data was used in comparing the protein systems.

\subsection{Experiment 3}

\subsubsection{Experimental animals and management}

Ten autumn-calving Ayrshire cows were used in a changeover trial of five periods, each lasting 25 days. Five of the cows were primiparous and five were multiparous. At the beginning of the experiment the average time since calving was 50 days ( 8 to 84 days). The cows were individually fed in a cowshed, having free access to silage at all times. Concentrate was fed at the fixed rate of $8 \mathrm{~kg}$ per day. In addition, $250 \mathrm{~g}$ of a mineral mixture $(17.0 \%$ $\mathrm{Ca}, 8.0 \% \mathrm{P}, 6.0 \% \mathrm{Mg}, 6.0 \% \mathrm{Na}$ ) was given daily. No hay was offered. The cows were weighed on two consecutive days in the beginning, in the middle and at the end of each period, always before the afternoon feeding. The change in live weight was calculated by regression.

\subsubsection{Experimental design and treatments}

An experimental design of two balanced 5x5 Latin squares was used. Multiparous cows were assigned to one square and primiparous cows to another. The treatments consisted of different ratios or treatments of rape seed meal in the diet. The control treatment (A) consisted of a diet devoid of RSM, in which a mixture of barley and oat (ratio 1:1) was given as concentrate. The grain was partially replaced by varying quantities of heat-moisture treated (Öpex) double zero RSM (var. "Esko"), in treatment B by $12 \%$, and in treatment C by $24 \%$. Treatment D contained $24 \%$ untreated single zero RSM (var. "Emma"), and treatment E 24\% untreated, glucosinolate-reduced double zero RSM treated with $\mathrm{FeSO}_{4}$.

\subsubsection{Feeds}

The direct cut silage came from swards of first cut timothy and meadow fescue. It was harvested by precision harvester, treated with 5 litres of formic acid $(80 \%)$ per tonne of grass, and stored in bunker silos.

The double zero RSM in treatments B and C was heat and moisture treated by the same method as in experiment 2 (Öpex treatment at the plant of Öljynpuristamo Oy). In treatment D the single zero RSM was not heat-treated, and in treatment $\mathrm{E}$, instead of the heat and moisture treatment, the double zero RSM was treated with ferrosulphate to increase the breakdown of glucosinolates. The RSM of single zero variety "Emma" was not quite pure, however, 
as some double zero RSM of variety "Kova" was mixed with it. The total glucosinolate content, measured by high performance liquid gas chromatography (HPLC), was 28,13 and $7 \mu \mathrm{mol} / \mathrm{g}$ fat-free meal respectively for the single zero variety "Emma", heat treated double zero variety "Esko" and glucosinolate-reduced double zero "Esko".

\subsubsection{Sampling and analytical methods}

The weekly samples of silage were analysed for dry matter and $\mathrm{pH}$, and then pooled over each experimental period. Samples of concentrates (grain, RSM) were taken in the last week of each test period and analysed separately. In addition to the analyses described under experiments 1 and 2, neutral detergent fiber (NDF), acid detergent fiber $(\mathrm{ADF})$ and acid detergent lignin (ADL) were determined according to GoERING and VAN SOEST (1970). Acid insoluble ash was determined from feeds and faeces with 2-N HCL according to VAN Keulen and Young (1977). The glucosinolate contents of various rapeseed meals were measured by HPLC according to BJÖRKQVIST and HASE (1988) at the Department of Chemistry, Helsinki University of Technology.

Degradation of protein in sacco was determined using a cow, which was given $2 \mathrm{~kg}$ of hay, $6 \mathrm{~kg}$ of concentrate, and silage ad libitum daily. The concentrate contained oat, barley and RSM. The incubation times of concentrates were 3, 6, 12, 24 and 48 hours, with an additional 72 hours for silage. For all feeds the loss due to washing off, and for concentrates the loss of particles containing protein in the bag were determined. Particle loss was taken as the difference between washing loss and soluble loss. Soluble loss of crude protein was determined by taking a sample of ca. $1 \mathrm{~g}$, incubating it in water for one hour at $39^{\circ} \mathrm{C}$, centrifuging and washing it three times, after which the amount of nitrogen in the precipitate was determined (HUHTANEN 1991).

Milk samples were collected from four consecutive milkings during the last two weeks of each trial period. Milk fat, protein and lactose contents were determined by the Valio laboratory using the IR technique on a MilkoScan 605. The pooled samples of the last week of each trial period were analysed for urea (RAJAMÄKI and RAURAMAA 1984) by the Valio laboratory, and for goitrin (BENNS et al. 1979, RAURAMAA 1983) by the laboratory of Viljavuuspalvelu Oy. The goitrin content was measured from the samples of primiparous cows only.

The apparent digestibility of the diets was measured using acid-insoluble acid as marker (VAN Keulen and Young 1977). During the last five days of each trial period faeces samples were taken twice a day from the rectum of each cow. The individual samples were pooled into one sample per period, and kept frozen until analysed upon being dried at $100^{\circ} \mathrm{C}$ for 72 hours and milled through a $1.5 \mathrm{~mm}$ screen.

\subsubsection{Statistical analysis}

The production data was analysed in terms of least squares variance (HARVEY 1966) using WSYS statistical software (VILVA 1989) and following the model:

$$
\begin{aligned}
y_{i j k l m}= & \underset{ }{\mu}+S_{i}+C_{j}\left(S_{i}\right)+P_{k}+T_{1}+(S * P)_{i k} \\
& (S * T)_{i l}+\varepsilon_{i j k l m}
\end{aligned}
$$

where $S_{i}, C_{j}, P_{k}$ and $T_{1}$ are the effects of the square, the cows in the squares, the period and the treatment, respectively. The residual degree of freedom was 24 . The effect of the treatment was further analysed using contrasts (SNEDECOR and COCHRAN 1980):

C1 linear effect of heat-moisture treated double zero variety RSM

C2 quadratic effect of heat-moisture treated double zero variety RSM

C3 effect of variety (zero variety diet D versus double zero variety diet E). The effect of $\mathrm{FeSO}_{4}$ treatment was confounded.

C4 effect of heat treatment of RSM: heat treated RSM on diet $\mathrm{C}$ versus untreated RSM on diet $\mathrm{E}$; the effect $\mathrm{FeSO}_{4}$ treatment confounded. 


\subsection{Experiment 4}

\subsubsection{Animals and management}

Sixteen autumn-calving Ayrshire cows were in a changeover trial covering four periods. The length of each period was 28 days. Eight of the cows were primiparous and the other eight multiparous. The average time lapse since calving to the beginning of the experiment was 89 days. The multiparous cows had calved 4.9 times on average. The cows were housed and individually fed in a cowshed with separate stalls, where they had free access to forage for 12 hours a day. They were given hay or silage at 6 a.m. and 1 p.m, and concentrates at 8 a.m. and 12 noon. Forage (hay or silage) was available ad libitum, whereas concentrates were rationed to $7.5 \mathrm{~kg}$ daily throughout the experiment. The daily diet was supplement with 250 grams of mineral mixture (See exp. 3 for composition). The consumption of feed was measured every day, and the milk yield was measured at every milking. The cows were weighed on two consecutive days at the beginning and at the end of each period.

\subsubsection{Experimental design and treatments}

The experimental design was four $4 \times 4$ Latin squares. Two squares, one with primiparous and another with multiparous cows, were feeding on silage, while the cows in the other two squares were feeding on hay. There were four treatments within each square: $0,8,16$ or 24 per cent of RSM added to a concentrate containing mainly oat and barley.

\subsubsection{Feeds}

Direct cut silage and hay (a mixture of $20 \%$ timothy, $20 \%$ meadow fescue and $60 \%$ couch grass) were obtained from a sward cut for the first time in the season. In the spring the sward had been fertilized with $112 \mathrm{~kg}$ nitrogen, $22 \mathrm{~kg}$ phosphorus and $45 \mathrm{~kg}$ potassium per hectare. The grass was harvested with flail harvester, adding 4.9 litres of AIV-II-solution ( $80 \%$ formic acid) per tonne. The barn-dried hay was cut at the same time as the silage was harvested. The double zero variety "Esko" was used as RSM.

\subsubsection{Sampling and analytical methods}

Samples of silage and hay were taken weekly and the dry matter of both, in addition to the $\mathrm{pH}$ value of silage, were determined. Samples for feed analyses were taken during the last week of each period and analysed in the same manner as in experiment 3. Faeces samples were subjected to proximate and fiber analysis. Milk samples were taken once a week at morning and evening milkings and analysed at the laboratory of Lapinlahti Dairy for fat, protein and lactose, in addition to employing the NIR technique and Seralyzer reflection photometry for urea analysis. Milk samples taken during the last week of each period were analysed goitrin (BENNS et al. 1979, RAURAMAA 1983) by the Valio laboratory.

The energy content of feed, faeces and milk samples were measured with an adiabatic process on a Parr 1241 adiabatic bomb calorimeter. The energy values of milk samples were determined by soaking a filter paper in ca. $3.5 \mathrm{~g}$ of the sample and igniting it in the bomb.

Ruminal degradation of protein was determined in sacco using a cow. The cow was given grass silage, hay and concentrate. The incubation times of all feeds were $3,6,12,24,48$ and 72 hours. Washing off and particle loss from the bag were also determined.

The apparent digestibility of the diets was measured using acid insoluble ash as a marker (VAN KEULEN and Young 1977). Faeces were collected from the rectum twice a day during the last five days of each test period.

\subsubsection{Statistical analysis}

Production data was analysed for RSM levels by means of the least squares variance analysis (HARVEY 1966) with the general linear program of SAS $A$, (1989) following the model: 
$\mathrm{y}_{\mathrm{ijklmn}}=\mu+\mathrm{F}_{\mathrm{i}}+\mathrm{A}_{\mathrm{j}}+\mathrm{P}_{\mathrm{k}}+\mathrm{T}_{1}+\left(\mathrm{F}^{*} \mathrm{~A}\right)_{\mathrm{ij}}+\left(\mathrm{F}^{*} \mathrm{P}\right)_{\mathrm{ik}}+$ $\left(\mathrm{F}^{*} \mathrm{~T}\right)_{\mathrm{il}}+\left(\mathrm{A}^{*} \mathrm{P}\right)_{\mathrm{jk}}+\left(\mathrm{A}^{*} \mathrm{~T}\right)_{\mathrm{jl}}+\left(\mathrm{F}^{*} \mathrm{~A}^{*} \mathrm{P}\right)_{\mathrm{ijk}}+\left(\mathrm{F}^{*} \mathrm{~A}^{*} \mathrm{~T}\right)_{\mathrm{ijl}}$ $+\mathrm{C}_{\mathrm{m}}\left(\mathrm{F}_{\mathrm{i}}\right)+\mathrm{C}_{\mathrm{m}}\left(\mathrm{A}_{\mathrm{j}}\right)+\mathrm{C}_{\mathrm{m}}\left(\mathrm{F}^{*} \mathrm{~A}_{\mathrm{ij}}\right)+\varepsilon_{\mathrm{ijk} \mathrm{m} n}$

where $F_{i}, A_{i}, P_{k}, T_{1}$ and $C_{m}$ signify the effects of forage (silage vs. hay), the age of the cow (primiparous vs. multiparous), period, treatment and the animal's position in the square, respectively. The residual degree of freedom was 24 . The effect of the treatment was further partitioned into the effects of orthogonal contrasts (linear, quadratic and cubic).

\subsection{Experiment 5}

\subsubsection{Animals and management}

A changeover experiment of four test periods using fourteen autumn-calving Ayrshire cows. The length of each period was 28 days. Seven of the cows were primiparous, and the other seven multiparous. The time since calving averaged 53 days at the beginning of trial. The cows were housed as in experiment 3. Grass silage was available ad libitum, the concentrate being rationed to 8 $\mathrm{kg}$ per day during the whole experiment. The diet was supplemented daily with $250 \mathrm{~g}$ of a mineral mixture containing $16.8 \% \mathrm{Ca}, 7.7 \% \mathrm{P}, 6.0 \% \mathrm{Mg}$ and $6.9 \% \mathrm{Na}$. The feeds were freely accessible at all times. The cows were weighed on two consecutive days at the beginning, in the middle and at the end of the period. The change in weight was calculated by regression.

\subsubsection{Experimental design and treatments}

A cyclic changeover design was used in the experiment (DAvis and HALL 1969), involving seven treatments, fourteen cows and four periods. The treatments consisted of diets including various proportions of SBM, treated SBM (TSBM), RSM, or treated RSM (TRSM) in the concentrate mixture (Table 13).
Table 13. Composition of concentrate mixtures in the experiment 5 .

Treat men t

Control RSM1 RSM2 TRSM SBM1 SBM2 TSBM2

\begin{tabular}{llllllll}
\hline Barley 100.0 & 44.0 & 38.0 & 44.0 & 45.8 & 41.6 & 45.8 \\
Oats & 100.0 & 44.0 & 38.0 & 44.0 & 45.8 & 41.6 & 45.8 \\
RSM & 12.0 & 24.0 & & & & \\
TRSM & & & 12.0 & & & \\
SBM & & & & 8.4 & 16.8 & \\
TSBM & & & & & & 8.4 \\
\hline
\end{tabular}

RSM $=$ rapeseed meal (00-var.), SBM = soybean meal, $\mathrm{T}=$ Oppex-treated meal

\subsubsection{Feeds}

Direct cut silage, containing predominantly timothy and meadow fescue, was harvested from swards for the first time in the season. The swards has been fertilized with $70 \mathrm{~kg}$ nitrogen, $30 \mathrm{~kg}$ phosphorus and $80 \mathrm{~kg}$ potassium per hectare. The silage was harvested with a fine chopper, and 4 to 5 litres of AIV-II solution ( $80 \%$ formic acid) was added to each tonne of silage as a preservative. SBM and RSM were extracted at Öljynpuristamo Oy. The soybeans were imported from USA, the rapeseed was of the Finnish double zero variety "Kova". Both SBM and RSM were either untreated after extraction, or heat-moisture treated (Öpexmethod by Öljynpuristamo Oy). The total quantity of glucosinolates, determined by HPLC, was 31 $\mu$ moles in seeds, $13 \mu$ moles in RSM, and $8 \mu$ moles in the treated RSM per gram of fat-free matter.

\subsubsection{Sampling and analytical methods}

The feeds were sampled and analysed as in experiment 3. Silage and hay were analysed for each period, the samples of concentrates were pooled for periods 1 and 2 and again for 3 and 4 . The glucosinolate contents were determined using HPLC (BJöRKVIST and HASE 1988) at the laboratory of Öljynpuristamo Oy. Amino acid content of rapeseed and soybean meals was analyzed using a gas chromatographic method (NÄSI and HUIDA 1982). 
Ruminal degradability of the feeds was measured in sacco using one heifer. The heifer was given grass silage, hay and $1.5 \mathrm{~kg}$ concentrate daily. The incubation times were 3, 6, 12, 24, 48 and 72 hours for concentrates, with an additional 96 hours for silage and hay. The loss through washing off the bag was determined for all feeds, as well as particle loss for concentrates.

Intestinal disappearance of protein was measured for intact rapeseed and soybean meals by the mobile nylon bag technique (HVELPLUND 1985, VARVIKKO and VANHATALO 1988). Approximately $1.1 \mathrm{~g}$ of feed was weighed in $3.5 \times 5.0 \mathrm{~cm}$ heat sealed polyester bags. The pore size of the cloth was $16 \mu \mathrm{m}$ and the open surface $5 \%$ of the area. The bags were introduced through the $\mathrm{T}$-cannula into the proximal duodenum. Once excreted, the bags were machine washed for 50 minutes at $40^{\circ} \mathrm{C}$. Initial incubations, averaging a batch of six bags each, were carried out in four heifers and one bull. After drying in $60^{\circ} \mathrm{C}$ all the residues of one batch (one incubation) were combined, milled through a 0.8 $\mathrm{mm}$ sieve and analyzed for nitrogen.

Milk samples were taken over 2 milkings and pooled to one sample in the third and fourth week of each test period. Milk fat, protein and lactose was determined by the IR-technique and urea was determined once in each period by the Valio laboratory.

The apparent digestibility of the diets was measured in multiparous cows, using acid insoluble ash (AIA) as a marker. The collection and treatment of faeces followed the method used in experiment 3 .

\subsubsection{Statistical analysis}

The following formula for statistical analysis was used:

$\mathrm{y}_{\mathrm{ijk} \mathrm{km}}=\mu+\mathrm{B}_{\mathrm{i}}+\mathrm{C}_{\mathrm{j}}\left(\mathrm{S}_{\mathrm{i}}\right)+\mathrm{P}_{\mathrm{k}}+\mathrm{T}_{1}+\left(\mathrm{B}^{*} \mathrm{P}\right)_{\mathrm{ik}}+\left(\mathrm{B}^{*} \mathrm{~T}\right)_{\mathrm{il}}+$ $\varepsilon_{\mathrm{ijklm}}$

where $B_{i}, C_{j}, P_{k}$ and $T_{1}$ are the effects of the block (viz. primiparity vs. multiparity), the cow in the block, the period and the treatment, respectively. The effect of the treatment was partitioned to the linear effect of protein level (C1), quadratic effect of protein level (C2), effect of SBM vs. RSM (C3) and effect of RSM treatment (C4).

\subsection{Estimating the effect of RSM on the milk and protein yield}

In each experiment there was a calculated deviation of the RSM group from the 0-RSM group for RSM intake and milk production. These deviations were used as measurements when calculating linear and non-linear regressions between RSM intake and production. Non-linear regression was calculated using the Gauss-Newton weighted least square technique (SAS 1989). Only RSM trials with varying proportions of RSM were included (Experiments 1, 3-6, 8-9).

The effect of treatment on protein protection of RSM was studied in experiments 1-3 and 5, in which a protected RSM group was included.

\subsection{Comparison of AAT-PBV and DCP systems}

Milk production experiments 1 to 8 were used as data for calculating the parameters, and their coefficient of variation, associated with the utilization of protein in milk production:

i. Linear regression between protein intake and production.

ii. Multiple regression, where protein production was explained in terms of protein intake and corrected ME-intake. The corrected ME was estimated by subtracting from the actual ME intake the intake adjusted for estimated regression, where ME intake was explained in terms of protein intake.

iii. Feed protein utilization in milk production: protein production by feed protein for production ( $\mathrm{g}$ milk protein/g feed protein). Feed protein conversion in milk production: feed protein for production by milk production ( $\mathrm{g}$ feed protein $/ \mathrm{kg}$ ECM). 


\section{Results and discussion}

\subsection{Composition and nutritional value of feeds}

\subsubsection{Chemical composition of feeds}

The chemical composition and energy and protein value of the feeds used in experiments 1 to 5 are is presented in Appendix 2, and Tables 14 and 15 contains a summary. The crude protein content of silage was fairly high in all experiments (mean $17.2 \%$, variation $16.3 \%$ to $18.5 \%$ in DM), while the crude protein content of RSM ranged from 32.7 to 39.1 per cent. The fat content of RSM was higher in experiments 1 to 4 , ca. $9 \%$ to $7 \%$ of DM, than in the fifth experiment, where it was $5 \%$ to $6 \%$ of DM.

The mean degradation parameters and AATPBV values of different feeds in experiments 1 to 5

Table 14. The average composition of the feeds (Exp. 1 - 5).

\begin{tabular}{|c|c|c|c|c|c|c|c|c|c|}
\hline & $\begin{array}{l}\text { No. of } \\
\text { analysis }\end{array}$ & DM, \% & $\begin{array}{l}\text { In DM, \% } \\
\text { Ash }\end{array}$ & $\begin{array}{l}\text { Crude } \\
\text { protein }\end{array}$ & $\begin{array}{l}\text { Ether } \\
\text { extract }\end{array}$ & $\begin{array}{l}\text { Crude } \\
\text { fibre }\end{array}$ & $\mathrm{NDF}^{1)}$ & $\mathrm{ADF}^{1)}$ & $\mathrm{ADL}^{1)}$ \\
\hline Silage & 28 & 22.9 & 7.1 & 17.2 & 5.6 & 28.1 & 50.8 & 29.2 & 1.9 \\
\hline Hay & 11 & 85.1 & 6.8 & 8.8 & 2.2 & 34.7 & 70.4 & 36.9 & 2.7 \\
\hline Hay(early cut) & 4 & 87.5 & 9.0 & 18.0 & 2.4 & 29.5 & 58.6 & 30.6 & 2.4 \\
\hline Barley & 14 & 82.5 & 2.6 & 11.8 & 2.8 & 5.1 & 20.5 & 5.4 & 0.8 \\
\hline Oat & 14 & 87.1 & 3.2 & 12.7 & 6.3 & 10.7 & 26.5 & 11.7 & 2.3 \\
\hline RSM & 15 & 88.7 & 7.6 & 36.0 & 8.0 & 12.7 & 27.5 & 19.0 & 8.6 \\
\hline TRSM(Öpex $)^{2)}$ & 13 & 88.1 & 7.8 & 34.9 & 8.3 & 13.0 & 27.1 & 18.5 & 7.9 \\
\hline SBM & 2 & 87.9 & 7.4 & 49.5 & 3.0 & 7.6 & 13.8 & 8.0 & 0.8 \\
\hline TSBM(Öpex $)^{2)}$ & 2 & 89.2 & 6.5 & 50.1 & 3.8 & 8.2 & 14.6 & 8.3 & 0.4 \\
\hline
\end{tabular}

1) NDF, ADF and ADL are determined only in Exp. 3-5. ${ }^{2}$ heat-moisture treatment for protein protection.

Average fermentation quality of silage: $\mathrm{pH} 3.94$; (percentage in DM): lactic acid 4.8, sugars 4.2, acetic acid 1.7, butyric acid 0.03 ; percentage of total $\mathrm{N}$ : soluble N 52.8 ; ammonium-N 4.1

Feeds fed in different experiments: Silage, barley, oats and RSM in all experiments; hay in Exp. 1,2 and 5; early cut hay in Exp. 4, RSM(Öpex) in Exp.1,2,3,4,5; SBM and SBM(Öpex) in Exp. 5.

Table 15. The average energy and protein values of the feeds (Exp. 1-5).

\begin{tabular}{lrrrrrrrrr}
\hline & Silage & Hay & $\begin{array}{l}\text { Hay } \\
\text { (early cut) }\end{array}$ & Barley & Oats & $\begin{array}{l}\text { RSM } \\
\text { Oppex }\end{array}$ & RSM & $\begin{array}{l}\text { SBM } \\
\text { Opex }\end{array}$ & $\begin{array}{c}\text { SBM } \\
\text { per kg DM: }\end{array}$ \\
FFU & 0.754 & 0.561 & 0.692 & 1.166 & 1.038 & 1.020 & 1.014 & 1.056 & 1.069 \\
ME, MJ & 10.64 & 9.18 & 10.14 & 13.62 & 12.34 & 12.12 & 12.07 & 12.46 & 12.58 \\
NEL, MJ & 5.92 & 5.19 & 5.90 & 7.99 & 7.20 & 7.26 & 7.23 & 7.48 & 7.56 \\
DCP, g & 124 & 53 & 128 & 88 & 102 & 299 & 290 & 445 & 451 \\
AAT, g & 76 & 75 & 80 & 103 & 72 & 141 & 157 & 183 & 242 \\
PBV,g & 40 & -42 & 42 & -49 & 9 & 149 & 115 & 223 & 146 \\
\hline
\end{tabular}

FFU = fattening feed unit $(0.7 \mathrm{~kg}$ starch), ME metabolizable energy according to MAFF (1975), NEL net energy in lactation according to VAN ES (1978), DCP digestible crude protein, AAT= absorbable amino acids in the duodenum, $\mathrm{PBV}=$ protein balance in the rumen.

Calculation of AAT/PBV-values: rumen outflow rate (k-value) 0.08 , EPD-values calculated according to ØrSKOV and MCDONALD (1979) and values for roughages are corrected for microbial N contamination in bag residues (MICHALET-DOREAU \& OULD-BAH 1989), true digestibility of UDP (TD.UDP) is constant 0.82 . 
are presented in Table 16. The mean values of degradation at different incubation times of feeds in experiments 3 to 5 are given in Appendix 2. The calculation methods of EPD and AAT-PBV values follow the system in general (See footnote in Table 15), except that there is no correction for degradation according to particle loss from the bag during incubation (HVELPLUND and MADSEN 1990).

The average degradability of the silage protein was low (Table 16). In the first two experiments the EPD of silage was only $59 \%$ to $68 \%$ (with micro- bial nitrogen adjustment), but rose to between $81 \%$ and $87 \%$ in the other experiments.

The effect of heat treatment on oilseed meals varied (Table 17). In the first experiment the EPD value of dry-heated RSM was only $11 \%$, while that of the untreated RSM was $50 \%$. In experiment 3 there was only a slight difference in EPD between the untreated and heat-treated RSM. In experiment 4 treated and untreated RSM were not compared, as only Öpex-treated RSM was used. That RSM was relatively highly degradable. In experiments 2 and

Table 16. The average values for protein degradation parameters and AAT-PBV values of the different feeds (Exp. 1-5).

\begin{tabular}{|c|c|c|c|c|c|c|c|c|c|}
\hline & $\begin{array}{l}\text { Degr } \\
\text { a }\end{array}$ & $\begin{array}{c}\text { on parar } \\
b\end{array}$ & $\begin{array}{l}\mathrm{s} \% \\
\mathrm{c}\end{array}$ & $\begin{array}{l}\text { Micr.N } \\
\text { corr. }\end{array}$ & EPD, \% & $\begin{array}{l}\text { AAT, } \\
\text { MPS, } \\
\text { g/kg DM }\end{array}$ & $\begin{array}{l}\text { AAT, } \\
\text { UDP, } \\
\text { g/kg DM }\end{array}$ & $\begin{array}{l}\text { AAT, } \\
\text { total } \\
\mathrm{g} / \mathrm{kg} \mathrm{DM}\end{array}$ & $\begin{array}{l}\text { PBV } \\
\text { g/kg DM }\end{array}$ \\
\hline Silage & 43.9 & 45.7 & 0.088 & 8.6 & 74.9 & 53.3 & 22.5 & 75.8 & 40.2 \\
\hline Hay & 21.5 & 48.9 & 0.098 & 14.3 & 61.5 & 57.4 & 17.8 & 75.2 & -42.0 \\
\hline Hay,e & 44.2 & 41.6 & 0.092 & 8.1 & 74.2 & 54.8 & 24.7 & 79.6 & 41.6 \\
\hline Barley & 23.3 & 71.4 & 0.150 & & 69.0 & 77.3 & 25.4 & 102.7 & -48.5 \\
\hline Oat & 67.7 & 25.6 & 0.218 & & 86.3 & 60.0 & 11.9 & 71.9 & 8.7 \\
\hline RSM & 19.5 & 75.7 & 0.086 & & 57.8 & 35.4 & 105.2 & 140.6 & 149.4 \\
\hline RSM-Öpex & 6.1 & 82.6 & 0.099 & & 50.5 & 35.9 & 121.3 & 157.1 & 114.6 \\
\hline SBM & 20.0 & 82.7 & 0.065 & & 57.2 & 35.6 & 147.7 & 183.3 & 223.3 \\
\hline SBM-Öpex & 9.3 & 100.4 & 0.037 & & 40.8 & 35.0 & 206.9 & 241.9 & 145.7 \\
\hline
\end{tabular}

Calculation of AAT/PBV-values: see footnote in Table 15.

Table 17. Protein degradation parameters and AAT-PBV values of RSM in the different experiments.

\begin{tabular}{|c|c|c|c|c|c|c|c|c|c|c|}
\hline $\begin{array}{l}\text { Ex } \\
\text { no }\end{array}$ & & Treatment & & $\begin{array}{c}\text { ion par } \\
\mathrm{b}\end{array}$ & $\begin{array}{c}\text { ers } \% \\
\text { c }\end{array}$ & EPD, \% & $\begin{array}{l}\text { AAT, } \\
\text { MPS, }\end{array}$ & $\begin{array}{l}\text { AAT, } \\
\text { UDP, }\end{array}$ & $\begin{array}{r}\text { AAT, } \\
\text { total }\end{array}$ & $\begin{array}{r}\text { PBV } \\
\mathrm{g} / \mathrm{kg} \mathrm{DM}\end{array}$ \\
\hline 1 & RSM-0 & Untreated & 19.8 & 78.1 & 0.050 & 49.8 & 34.8 & 123.8 & 158.5 & 117.5 \\
\hline & RSM-00 & Heated & 4.3 & 71.2 & 0.008 & 10.4 & 32.3 & 253.1 & 285.4 & -12.3 \\
\hline 2 & RSM-0 & Untreated & 22.5 & 72.4 & 0.080 & 58.7 & 36.3 & 104.0 & 140.3 & 151.2 \\
\hline & RSM-0 & Öpex & 1.8 & 72.1 & 0.085 & 38.9 & 36.3 & 152.0 & 188.3 & 77.6 \\
\hline 3 & RSM-00 & $\mathrm{FeSO}_{4}$ & 4.6 & 88.8 & 0.115 & 56.9 & 34.6 & 100.1 & 134.7 & 131.4 \\
\hline & RSM-0 & Untreated & 7.4 & 84.9 & 0.118 & 58.0 & 35.6 & 97.8 & 133.4 & 133.8 \\
\hline & RSM-00 & Öpex & 3.2 & 95.6 & 0.103 & 50.7 & 35.5 & 114.2 & 149.8 & 108.9 \\
\hline 4 & RSM-00 & Öpex & 12.7 & 79.3 & 0.147 & 64.2 & 36.2 & 81.8 & 118.0 & 149.0 \\
\hline 5 & RSM-00 & Untreated & 29.8 & 65.4 & 0.095 & 65.3 & 35.4 & 94.4 & 129.8 & 195.8 \\
\hline & RSM-00 & Öpex & 13.2 & 83.2 & 0.059 & 48.2 & 35.4 & 136.8 & 172.2 & 123.2 \\
\hline
\end{tabular}

See footnotes in Tables 15 and 16 
5 EPD of untreated RSM was $59 \%$ and $65 \%$, and those of Öpex-treated RSM were $39 \%$ and $48 \%$ respectively.

\subsubsection{Intestinal degradation of RSM and SBM as measured by mobile nylon bag technique}

The disappearance in the intestines of intact samples of RSM and SBM in experiment 5 was measured using the mobile nylon bag technique (Table 18). Feeds were not treated with pepsin$\mathrm{HCl}$, as it has a negligible effect on the disappearance of feed crude protein (CP) in the intestine (VARViKKo and Vanhatalo 1991, Vanhatalo and ARONEN 1991). Measured with this technique, the heat-moisture treatment had no effect on the intestinal degradation of dry matter and crude protein, a finding also reported by VANHATALO and Aronen (1991).

The estimated true digestibility of UDP [TD.UDP $=(\mathrm{UDP}-\mathrm{TU}) / \mathrm{UDP}]$ was calculated using predetermined EPD values and the values for indigestible nitrogen of feeds determined in the present study. The true digestibility of UDP, as estimated with this technique, agreed with the results of VANHATALO and ARONEN (1991), when TD.UDP of SBM and RSM of the same varieties and treatments were measured with the bag technique after 10 hours' incubation in the rumen. Here estimates (based on the measured TU value) of true digestibility values of UDP were lower for RSM and higher

Table 18. Disappearance of DM and CP of intact RSM and SBM during intestinal incubation in mobile nylon bag (Exp. 5).

\begin{tabular}{lllll}
\hline & \multicolumn{2}{l}{$\begin{array}{l}\text { EPD (\%) } \\
\text { in the } \\
\text { rumen }\end{array}$} & $\begin{array}{l}\text { Intestinal } \\
\text { disappearance (\%) } \\
\text { DM }\end{array}$ & \multicolumn{2}{l}{ CP.UDP } \\
& & & & \\
& & & & \\
& & & & \\
RSM-untreated & 65.3 & 67.6 & 89.1 & 68.6 \\
RSM-Öpex & 48.2 & 68.6 & 89.1 & 79.0 \\
SBM-untreated & 57.1 & 85.3 & 97.1 & 93.2 \\
SBM-Öpex & 40.8 & 83.4 & 97.4 & 95.6 \\
S.E.1)1.971.17 & & & & \\
\hline
\end{tabular}

1) 5 animals, 4 feeds, 19 observations, resid. d.f. 11 (1 missing obs.) for SBM than using $7 \%$ as the TU value, as proposed in the AAT-PBV system (HVELPLUND 1990). Microbial-N contamination of the mobile bag residues was not taken into account in this estimate, but it was lower for concentrate feeds than for fibrous feeds (VARViKKo and Vanhatalo 1990).

\subsubsection{Amino acid content of RSM and SBM}

The amino acid contents of RSM and SBM were measured in experiment 5 (Table 19). After heat and moisture treatment the amino acid content of both RSM and SBM was reduced, but more markedly in RSM than in SBM. Especially the lysine, histidine and arginine contents had decreased by more than $15 \%$ in RSM, the corresponding reduction being only $4 \%$ to $7 \%$ in SBM. Earlier experiences concerning these have been variable: NÄSI and SILJANDER-RASI (1991) found heat and moisture treatment to have a minor effect on lysine content, whereas NÄsI et al. (1985) found a noticeable reduction in lysine and the available lysine content of dry-heat treated RSM. RAE et al. (1983)

Table 19. Amino acid composition of the RSM and SBM (both untreated and Öpex-heat-moisture treated ) in experiment 5 .

\begin{tabular}{|c|c|c|c|c|}
\hline & \multicolumn{4}{|l|}{$\mathrm{g} / 16 \mathrm{~g} \mathrm{~N}$} \\
\hline & Normal & Öpex & Normal & Öpex \\
\hline Lysine & 5.7 & 4.8 & 6.7 & 6.2 \\
\hline Histidine & 2.4 & 2.0 & 2.3 & 2.2 \\
\hline Arginine & 6.2 & 5.3 & 7.6 & 7.1 \\
\hline Aspartic acid & 7.9 & 7.4 & 11.4 & 11.0 \\
\hline Threonine & 4.9 & 4.6 & 4.2 & 4.1 \\
\hline Serine & 4.7 & 4.4 & 5.2 & 5.2 \\
\hline Glutamic acid & 17.2 & 15.5 & 18.3 & 17.9 \\
\hline Proline & 5.8 & 5.9 & 5.2 & 5.1 \\
\hline Glycine & 5.5 & 4.8 & 4.1 & 4.5 \\
\hline Alanine & 4.6 & 4.3 & 4.5 & 4.4 \\
\hline Valine & 5.4 & 5.2 & 4.8 & 4.6 \\
\hline Isoleucine & 4.7 & 4.6 & 4.8 & 4.7 \\
\hline Leucine & 7.5 & 7.0 & 7.9 & 7.8 \\
\hline Tyrosine & 3.4 & 3.2 & 4.0 & 3.9 \\
\hline Methionine & 1.5 & 1.4 & 0.8 & 0.7 \\
\hline Phenylalanine & 4.5 & 4.2 & 5.5 & 5.4 \\
\hline Total & 91.6 & 84.0 & 96.9 & 94.3 \\
\hline
\end{tabular}


reported that treating RSM with formaldehyde (1.2 g FA/100 g CP) reduced lysine content by $29 \%$. Formaldehyde treatment with 0.4 to $0.8 \mathrm{~g}$ FA per $100 \mathrm{~g} \mathrm{CP}$ decreased the lysine content only by $2 \%$ to $6 \%$ (SETÄLÄ and SYRJÄLÄ-QVIST 1984/85).

\subsubsection{Glucosinolate content of RSM}

A considerable reduction in glucosinolate content (Table 20) was observed between single-low (Experiments 1 and 2) and double-low varieties of rapeseed (Exp. 3, 4 and 5). The total quantity of glucosinolates was reduced from $40-50 \mu$ moles per gram of fat-free material in experiments 1 and 2 to $14 \mu$ moles per gram in experiment 5 . However, even the largest quantity of glucosinolates, 49 $\mu$ moles in exp. 2, is quite moderate compared to values ranging from 100 to $205 \mu \mathrm{moles} / \mathrm{g}$ for single-low canola meal (SHAHIDI 1990b).

In 1987 (Exp. 3) the single-low RSM was found to contain less glucosinolates than the canola standard of $30 \mu \mathrm{g}$ alkenylglucosinolates per one gram of defatted meal. That was due to the contamination of the single-low rapeseed with double-low varieties. The rapeseed meal produced in 1989 (Exp. 5) fulfilled the EEC standard of $20 \mu$ moles per gram of seed (included the indolylglucosinolates 4hydroxyglucobrassicin and glucobrassicin) (Table
21). Since the cultivation of the new turnip rapeseed variety, "Kulta", began in Finland, the glucosinolate content has dropped to below $10 \mu$ moles per gram of seed (VILKKI 1991).

The main glucosinolates of the double-low turnip rapeseed are progoitrin, glucobrassicanapin, gluconapin and 4-hydroxyglucobrassicin. The proportion of the last one has increased, while total quantity of glucosinolates has decreased. SANG and SALISBURY (1988) measured doubled proportions of that glucosinolate in double-low rapeseed compared to the single zero varieties (Table 10).

Having been crushed and extracted, the rapeseed meal contained about half the quantity of glucosinolates found in intact seeds, as calculated from defatted dry matter. The heat and moisture treatment of RSM further reduced the quantity to a half (Tables 20 and 21). Especially the proportion of 4hydroxyglucobrassicin had decreased during the processing, whereas the proportion of progoitrin had increased (Table 21). The analytical methods used do not, however, include measurements of the degraded products of glucosinolates. The presence of moisture during heating was found to be an essential factor in reducing the quantity of glucosinolates (REYNOLDS and YOUNG 1964, APPELQVIST and JoSEFSSON 1967, BELZILE et al. 1963, EAPEN et al. 1968, SHAHIDI and NACZK 1990).

Table 20. Glucosinolate content ( $\mu$ moles/g defatted meal) of the rapeseed meal in different experiments.

\begin{tabular}{|c|c|c|c|c|c|c|c|}
\hline $\begin{array}{l}\text { Exp. } \\
\text { no. }\end{array}$ & Origin & GNA & GBN & PRO & NAP & Others & Total \\
\hline \multirow[t]{2}{*}{1} & RSM0 (1983, B. camp.) & 10 & 21 & 10 & 2 & & 43 \\
\hline & TRSM (1983, B. napus) & 3 & 2 & 3 & 0 & & 8 \\
\hline \multirow[t]{2}{*}{2} & RSM0 (1984, B. camp.) & 14 & 11 & 21 & 3 & & 49 \\
\hline & TRSM0 (Öpex) (1984, B. camp.) & 3 & 4 & 7 & 1 & & 15 \\
\hline \multirow[t]{3}{*}{3} & RSM0 (1987, B. camp.) & 8 & 8 & 10 & 2 & & 28 \\
\hline & RSM00(Öpex) (1987, B. camp.) & 4 & 3 & 4 & 1 & 1 & 13 \\
\hline & $\mathrm{RSM} 00\left(\mathrm{FeSO}_{4}\right)(1987$, B. camp. $)$ & 2 & 1.5 & 2 & 1.5 & 1 & 7 \\
\hline \multirow[t]{2}{*}{5} & RSM00 (1989, B. camp.) & 1.4 & 3.4 & 5.6 & 0.8 & 2.3 & 13.5 \\
\hline & RSM00(Öpex) (1989, B. camp.) & 1.5 & 1.6 & 3.2 & 0.4 & 0.8 & 7.5 \\
\hline
\end{tabular}

TRSM (1983, B.napus) was of Danish origin, all others were of Finnish origin.

Treatments: 1983: dry-heated, 1984-1989 heat-moisture treated in a pressurized chamber; $\mathrm{FeSO}_{4}=$ reduced glucosinolates by $\mathrm{FeSO}_{4}$;

$\mathrm{GNA}=$ gluconapin, $\mathrm{GBN}=$ glucobrassicanapin, $\mathrm{PRO}=$ progoitrin, $\mathrm{NAP}=$ napoleiferin 
Table 21. Glucosinolate content of RSM in details from experiment 5.

\begin{tabular}{|c|c|c|c|c|c|c|}
\hline & \multicolumn{3}{|c|}{$\mu$ moles/g DM } & \multicolumn{3}{|c|}{$\mu$ moles $/ \mathrm{g}$ defatted matter } \\
\hline & Seed & RSM & TRSM & Seed & RSM & TRSM \\
\hline Gluconapin & 3.0 & 1.4 & 1.5 & 5.0 & 1.5 & 1.6 \\
\hline Glucobrassicanapin & 3.7 & 3.4 & 1.6 & 6.2 & 3.6 & 1.7 \\
\hline Progoitrin & 5.6 & 5.6 & 3.2 & 9.3 & 5.9 & 3.4 \\
\hline Napoleiferin & 0.9 & 0.8 & 0.4 & 1.5 & 0.8 & 0.4 \\
\hline Gluconasturtiin & 0.2 & 0.2 & 0.1 & 0.3 & 0.2 & 0.1 \\
\hline Glucobrassicin & 0.1 & 0.05 & 0 & 0.2 & 0.05 & 0 \\
\hline Neoglucobrassicin & 0.03 & 0 & 0 & 0.05 & 0 & 0 \\
\hline 4-hydroxyglucobrassicin & 3.0 & 0.5 & 0.06 & 5.0 & 0.5 & 0.06 \\
\hline $\mathrm{S} 1^{1)}$ & 0.8 & 0.7 & 0.4 & 1.3 & 0.7 & 0.4 \\
\hline $\mathrm{S} 2$ & 1.0 & 0.4 & 0 & 1.7 & 0.4 & 0 \\
\hline S3 & 0.2 & 0.2 & 0.1 & 0.3 & 0.2 & 0.1 \\
\hline Others & 0.3 & 0.2 & 0.1 & 0.5 & 0.2 & 0.1 \\
\hline Total & 18.83 & 13.45 & 7.46 & 31.35 & 14.05 & 7.86 \\
\hline -indolyl glucosinolates & 3.13 & 0.55 & 0.06 & 5.22 & 0.58 & 0.06 \\
\hline
\end{tabular}

Table 22. The effect of RSM on the digestibility of the diet.

\begin{tabular}{|c|c|c|c|c|c|c|c|c|c|}
\hline & \multicolumn{5}{|c|}{ RSM-level in the concentrate $(\%)$} & \multirow[t]{2}{*}{ S.E. } & \multicolumn{3}{|c|}{ Significance of contrasts } \\
\hline & 0 & 8 & 12 & 16 & 24 & & Lin. & Quadr. & Cubic \\
\hline \multicolumn{10}{|c|}{ Experiment 3} \\
\hline $\mathrm{OM}$ & 76.6 & - & 77.2 & - & 74.7 & 1.21 & 0.73 & 0.22 & \\
\hline $\mathrm{CP}$ & 72.4 & - & 74.5 & - & 74.4 & 1.13 & $<0.001$ & 0.024 & \\
\hline EE & 61.9 & - & 67.8 & - & 67.8 & 4.41 & 0.007 & 0.10 & \\
\hline CF & 67.7 & - & 68.4 & - & 68.4 & 1.95 & 0.49 & 0.61 & \\
\hline NFE & 82.1 & - & 82.2 & - & 81.7 & 1.05 & 0.49 & 0.45 & \\
\hline NDF & 65.7 & - & 67.2 & - & 67.3 & 2.01 & 0.081 & 0.38 & \\
\hline $\mathrm{ADF}^{\prime}$ & 67.0 & - & 67.8 & - & 67.6 & 2.01 & 0.54 & 0.52 & \\
\hline $\mathrm{HMC}$ & 64.2 & - & 66.5 & - & 67.0 & 2.13 & 0.006 & 0.29 & \\
\hline CEL & 73.9 & - & 75.2 & - & 76.0 & 1.72 & 0.010 & 0.67 & \\
\hline \multicolumn{10}{|c|}{ Experiment 4} \\
\hline $\mathrm{OM}$ & 78.6 & 79.2 & - & 79.2 & 79.4 & 1.52 & 0.16 & 0.62 & 0.64 \\
\hline $\mathrm{CP}$ & 76.5 & 77.6 & - & 78.4 & 79.0 & 1.66 & $<0.001$ & 0.48 & 0.91 \\
\hline CF & 68.0 & 68.1 & - & 69.4 & 70.1 & 2.46 & 0.010 & 0.61 & 0.55 \\
\hline NFE & 82.4 & 83.0 & - & 82.7 & 82.7 & 1.35 & 0.68 & 0.48 & 0.43 \\
\hline NDF & 67.6 & 68.3 & - & 69.4 & 70.1 & 2.29 & 0.002 & 0.96 & 0.81 \\
\hline ADF & 66.8 & 67.5 & - & 68.4 & 68.7 & 2.80 & 0.041 & 0.79 & 0.85 \\
\hline $\mathrm{HMC}$ & 68.3 & 69.0 & - & 70.3 & 71.5 & 2.84 & 0.002 & 0.68 & 0.81 \\
\hline CEL & 72.4 & 74.0 & - & 75.4 & 76.3 & 2.76 & $<0.001$ & 0.63 & 0.90 \\
\hline \multicolumn{10}{|c|}{ Experiment 5} \\
\hline $\mathrm{OM}$ & 74.7 & - & 75.4 & - & 74.6 & 0.94 & 0.88 & 0.21 & \\
\hline CP & 69.1 & - & 71.8 & - & 72.2 & 1.80 & 0.046 & 0.37 & \\
\hline $\mathrm{EE}$ & 64.1 & - & 65.5 & - & 64.4 & 1.77 & 0.776 & 0.32 & \\
\hline CF & 66.3 & - & 66.6 & - & 65.4 & 1.85 & 0.51 & 0.56 & \\
\hline NFE & 80.2 & - & 80.7 & - & 79.7 & 0.81 & 0.47 & 0.19 & \\
\hline NDF & 67.6 & - & 68.9 & - & 67.6 & 1.35 & 0.99 & 0.18 & \\
\hline $\mathrm{ADF}$ & 68.7 & - & 68.8 & - & 66.9 & 1.52 & 0.13 & 0.34 & \\
\hline HMC & 66.5 & - & 69.0 & - & 68.4 & 1.29 & 0.077 & 0.096 & \\
\hline CEL & 72.7 & - & 74.6 & - & 73.5 & 1.60 & 0.54 & 0.21 & \\
\hline
\end{tabular}

$\mathrm{HMC}=\mathrm{NDF}-\mathrm{ADF}$ (hemicellulose) 


\subsection{Effect of protein supplement on the digest- ibility of the diet}

The digestibility of the diet was measured in three experiments. In all three experiments the digestibility of crude protein increased significantly (Table 22). This has been reported in most experiments comparing different proportions of protein in feeds. The increase in the apparent digestibility of $\mathrm{CP}$ is largely attributable to the declining proportion of metabolic faecal N in total faecal N (GORDON 1980, Holter et al. 1982, RAE et al. 1983, MAYNE and Gordon 1984, MurPhy et al. 1985, PeOPles and Gordon 1989, CoDy et al. 1990). There are only few other reports of increased digestibility of fiber (Exp. 4.) (PEOPLES and GoRDON 1989). RSM had no effect on the digestibility of $\mathrm{OM}$ in the diet, but soybean meal had a positive linear effect $(\mathrm{P}=0.03)$ on the digestibility of OM. The same was observed by GORDON (1980) and HoLTER et al. (1982).

\subsection{Effect of proportion of RSM on milk pro- duction}

\subsubsection{Feed intake}

Details of the results of the experiments 1, 3, 4 and 5 (Experiments with different RSM levels) are given in Appendix 3. In all experiments a part of the grain was replaced by RSM, so that the total concentrate allowance was equal and forage was given ad libitum.

A significant increase in the intake of grass silage of $6 \%$ to $10 \%$, attributable to RSM, was observed in one experiment only (Exp. 3). In experiments 4 and 5 the forage intake was higher in the control group, which had plain grain as a concentrate. In this case, however, the intake of concentrate by the control groups was lower, because they had more leftovers than the groups given RSM.

Table 24 shows the responses to increased intake of RSM or increased crude protein content. The data is based on experiments $1,3,4$ to 6,8 and 9, (excluding the group with the high RSM level in experiment 1 , due to reduced feed intake; a total of
24 observations). The observations are deviations between RSM and control group. The responses were positive, but with great variations, as reported by Chamberlain et al. (1989) and noted in the review (Table 23) of data collected on ad libitum silage feeding and in, most cases, fixed quantity of concentrate. SMALL and GORDON (1990) calculated the response to the total DM intake of $0.10 \mathrm{~kg}$ per $100 \mathrm{~g}$ increase in supplementary protein intake (SCPI). In the present study the response was greater, $0.14 \mathrm{~kg} \mathrm{DM} / \mathrm{SCPI}$.

\subsubsection{Milk yield}

In experiments 3, 4 and 5 (Appendix 3) a significant positive linear effect of RSM level on the milk yield was observed. In Experiment 1 milk yield increased at 0 -RSM level $1(20 \%$ RSM in the concentrate), but decreased at level 2 (33\% 0-RSM in the concentrate). The ECM (energy-corrected milk) value decreased by ca. $4 \%$, the main reason being the reduced concentrate intake of that group. The high glucosinolate content of these meals is likely to have affected the concentrate intake. Furthermore, a reduction in the intake of concentrate by the group given $20 \%$ dry-heat treated rapeseed meal was observed. The protein degradation rate of that RSM was only $11 \%$ (Table 17), and the lysine content was reduced. The heat treatment had probably been too severe, affecting the palatability, and thus the intake, of the concentrate.

The RSM supplement had no significant effect on the milk protein content. In experiment 4 the milk fat content was significantly decreased by RSM, but there was no similar effect in the other experiments. Fat content of RSM in experiment 4 was $9.4 \%$ and proportion of rapeseed fat in the total diet was higher than in other experiments, which may have reduced fat content of milk as reported Tesfa et al. (1991) and Tesfa (1992). After calculating the deviations between the RSM groups and the control group (the same data was used to calculate feed intake) in milk yield and protein composition and RSM or ME (metabolisable energy) intake, linear regressions between the intake and 
Table 23. The effect of protein supplements on the performance of lactating cows on ad lib. silage feeding (a review).

\begin{tabular}{|c|c|c|c|c|c|c|c|}
\hline \multirow{2}{*}{$\begin{array}{l}\text { Silage } \\
\text { CP } \\
(\% \text { in D }\end{array}$} & \multirow{2}{*}{$\begin{array}{l}\text { Protein } \\
\text { supplem. } \\
\text { M) }\end{array}$} & \multirow{2}{*}{$\begin{array}{l}\text { Variation in } \\
\text { the CP-\% of } \\
\text { concentr. DM }\end{array}$} & \multicolumn{4}{|c|}{$\begin{array}{l}\text { Response per } 10 \mathrm{~g} / \mathrm{kg} \text { increase } \\
\text { of concentrate } \mathrm{CP}\end{array}$} & \multirow[t]{2}{*}{ Source } \\
\hline & & & $\begin{array}{l}\text { Milk } \\
\text { yield } \\
(\mathrm{kg} / \mathrm{d})\end{array}$ & $\begin{array}{r}\text { Protein } \\
\text { yield } \\
(\mathrm{g} / \mathrm{d})\end{array}$ & $\begin{array}{r}\text { Protein } \\
\text { content } \\
(\mathrm{g} / \mathrm{kg})\end{array}$ & $\begin{array}{r}\text { Silage } \\
\text { intake } \\
(\mathrm{kg} \mathrm{DM} / \mathrm{d})\end{array}$ & \\
\hline \multirow[t]{3}{*}{14.2} & SBM & $10.9-15.8$ & 0.28 & 12.0 & 0.18 & 0.03 & \multirow[t]{3}{*}{ GORDON 1979} \\
\hline & $“$ & $10.9-20.0$ & 0.27 & 11.5 & 0.16 & 0.05 & \\
\hline & “ & $10.9-24.0$ & 0.28 & 10.2 & 0.08 & 0.03 & \\
\hline \multirow[t]{5}{*}{16.7} & SBM & $11.8-15.5$ & 0.06 & 6.2 & 0.24 & & \multirow{5}{*}{$\begin{array}{l}\text { GORDON \& } \\
\text { MCMURRAY } 1979\end{array}$} \\
\hline & “ & $11.8-19.8$ & 0.19 & 10.1 & 0.25 & & \\
\hline & “ & $11.8-24.0$ & 0.16 & 9.6 & 0.25 & & \\
\hline & “ & $11.8-28.9$ & 0.17 & 7.1 & 0.11 & & \\
\hline & “ & $11.8-34.4$ & 0.08 & 4.5 & 0.11 & & \\
\hline 12.4 & GNC & $15.8-20.2$ & 0.48 & 16.8 & 0.11 & 0.19 & LAIRD et al.1979 \\
\hline 12.3 & SBM & $15.5-20.1$ & 0.20 & & 0.0 & & Tномаs et al.1984 \\
\hline 12.8 & $“$ & $15.5-20.1$ & 0.13 & & -0.04 & & \\
\hline 18.2 & $“$ & $15.5-20.1$ & 0.35 & & 0.22 & & \\
\hline \multirow[t]{2}{*}{11.9} & SBM & $10.0-17.0$ & 0.43 & 19.7 & 0.29 & $0.31^{1)}$ & \multirow{2}{*}{$\begin{array}{l}\text { BURGESS \& } \\
\text { NiCHOLSON } 1984\end{array}$} \\
\hline & “ & $10.0-24.6$ & 0.27 & 9.6 & 0.04 & $0.10^{1)}$ & \\
\hline \multirow[t]{3}{*}{11.3} & SBM & $14.2-17.3$ & 0.06 & 6.8 & 0.29 & -0.03 & \multirow{3}{*}{$\begin{array}{l}\text { MAYNE \& GORDON } \\
1985\end{array}$} \\
\hline & $“$ & $14.2-20.7$ & 0.09 & 5.7 & 0.17 & 0.00 & \\
\hline & $“$ & $14.2-24.1$ & 0.10 & 5.8 & 0.16 & 0.03 & \\
\hline \multirow[t]{2}{*}{12.7} & SBM & $12.7-20.7$ & 0.13 & 8.5 & 0.24 & 0.07 & \multirow{2}{*}{$\begin{array}{l}\text { MURPHY et. al. } \\
1985\end{array}$} \\
\hline & RSM & $12.7-20.4$ & 0.12 & 7.3 & 0.19 & 0.06 & \\
\hline \multirow[t]{2}{*}{12.8} & SBM & $19.3-25.0$ & 0.05 & 4.2 & 0.02 & & \multirow{2}{*}{$\begin{array}{l}\text { GORDON \& } \\
\text { UNSWORTH } 1986\end{array}$} \\
\hline & & & & & & & \\
\hline \multirow[t]{2}{*}{15.2} & SBM & $18.4-25.1$ & 0.10 & 4.2 & 0.06 & 0.03 & \multirow{6}{*}{$\begin{array}{l}\text { PEOPLES \& } \\
\text { GORDON } 1989 \\
\text { HEIKKIL.Ả et al. } \\
1989\end{array}$} \\
\hline & & & & & & & \\
\hline 20.0 & RSM & $13.5-16.0$ & 0.24 & 14.8 & 0.32 & 0.00 & \\
\hline & “ & $13.5-18.0$ & 0.11 & 9.6 & 0.27 & -0.09 & \\
\hline \multirow[t]{2}{*}{16.0} & $"$ & $13.5-16.0$ & 0.28 & 14.0 & 0.24 & 0.40 & \\
\hline & " & $13.5-18.0$ & 0.13 & 9.1 & 0.22 & 0.22 & \\
\hline 15.7 & SBM & $12.2-21.0$ & 0.19 & 8.1 & 0.14 & 0.07 & CoDy et al. 1990 \\
\hline 18.7 & SBM,FM & $17.5-22.9$ & 0.13 & 7.4 & 0.13 & 0.08 & $\begin{array}{l}\text { SMALL \& GORDON } \\
1990\end{array}$ \\
\hline 14.2 & RSM & $12.7-16.2$ & 0.23 & 15.0 & 0.32 & 0.06 & $\begin{array}{l}\text { HUHTANEN et al. } \\
1991\end{array}$ \\
\hline \multirow[t]{4}{*}{15.5} & RSM & $13.3-17.1$ & 0.52 & 17.8 & 0.03 & -0.10 & \multirow{4}{*}{$\begin{array}{l}\text { HUHTANEN } 1992 \\
\text { (unpublished) }\end{array}$} \\
\hline & $"$ & $14.2-17.8$ & 0.37 & 22.4 & 0.22 & 0.08 & \\
\hline & $"$ & $15.8-19.6$ & 0.35 & 14.7 & 0.10 & 0.23 & \\
\hline & $"$ & $16.5-20.2$ & 0.36 & 15.1 & 0.14 & 0.10 & \\
\hline
\end{tabular}

$\mathrm{FM}=$ fish meal, $\mathrm{GNC}=$ groundnut cubes, $\mathrm{RSM}=$ rapeseed meal, $\mathrm{SBM}=$ soybean meal;

1) total DM intake 
Table 24. Responses of intake when increasing rapeseed meal or crude protein content in the concentrate or diet $(n=24)$.

\begin{tabular}{|c|c|c|c|c|}
\hline & Mean & s.d. & Min. & Max. \\
\hline \multicolumn{5}{|c|}{ per $\mathrm{kg}$ increase of RSM DM } \\
\hline Forage & 0.15 & 0.43 & -0.58 & 1.45 \\
\hline Total intake & 0.34 & 0.40 & -0.35 & 1.59 \\
\hline \multicolumn{5}{|c|}{ per $10 \mathrm{~g}$ increase of concentrate $\mathrm{CP}$ (in DM) } \\
\hline Forage & 0.05 & 0.13 & -0.18 & 0.40 \\
\hline Total intake & 0.11 & 0.12 & -0.111 & 0.44 \\
\hline \multicolumn{5}{|c|}{ per $10 \mathrm{~g}$ increase of diet CP (in DM) } \\
\hline Forage & 0.11 & 0.32 & -0.45 & 0.96 \\
\hline Total intake & 0.27 & 0.30 & -0.27 & 1.06 \\
\hline
\end{tabular}

production parameters were calculated (Table 25). The non-linear regressions are shown in Table 26 and Figures 1-4. The determination coefficients for nonlinear equations were calculated from the regressions between the actual and regressed variable Y's (Table 26).

The effect of RSM on the milk and protein yield deviate only slightly from the linearity, as can be seen from the determination of coefficients in Tables 25 and 26. This is due to the maximum quantities of RSM having been reasonable, the largest being only $1.7 \mathrm{~kg}$ DM per day. The reactions in terms of milk yield to the intake of increased quantities of RSM can be calculated from the exponen-

Table 25. Linear regressions estimating the response in milk and protein yield and content: $Y=a+b_{1} X_{1}\left(X_{1}=\right.$ change in intake or content of the diet).

\begin{tabular}{|c|c|c|c|c|c|c|}
\hline $\begin{array}{l}\text { Dependent } \\
\text { variable Y }\end{array}$ & $\begin{array}{l}\text { Independent } \\
\text { variable X }\end{array}$ & a & b & $\mathrm{R}^{2}$ & S.E. & $\begin{array}{r}\text { Significance } \\
\text { (P-value) }\end{array}$ \\
\hline$\Delta$ milk yield $(\mathrm{kg} / \mathrm{d})$ & $\Delta \mathrm{RSM}(\mathrm{kg} \mathrm{DM} / \mathrm{d})$ & 0.168 & 0.77 & 22.4 & 0.56 & 0.020 \\
\hline$\triangle \mathrm{ECM}(\mathrm{kg} / \mathrm{d})$ & $\triangle \mathrm{RSM} \quad$ “ & 0.235 & 0.70 & 23.5 & 0.49 & 0.016 \\
\hline$\Delta$ protein yield $(\mathrm{g} / \mathrm{d})$ & $\triangle \mathrm{RSM} \quad$ " & 6.75 & 29.2 & 31.1 & 17.1 & 0.005 \\
\hline$\Delta$ milk yield $(\mathrm{kg} / \mathrm{d})$ & $\Delta \mathrm{CP}_{\mathrm{c}}(\mathrm{g} / \mathrm{kg} \mathrm{DM})$ & -0.01 & 0.28 & 33.3 & 0.52 & 0.003 \\
\hline$\triangle \mathrm{ECM}$ yield $(\mathrm{kg} / \mathrm{d})$ & $\Delta \mathrm{CP}_{c} \quad$ " & 0.32 & 0.19 & 19.7 & 0.51 & 0.030 \\
\hline$\Delta$ protein yield $(\mathrm{g} / \mathrm{d})$ & $\Delta \mathrm{CP}_{\mathrm{c}} \quad$ “ & 11.3 & 7.9 & 24.5 & 17.9 & 0.014 \\
\hline$\Delta$ milk yield $(\mathrm{kg} / \mathrm{d})$ & $\Delta \mathrm{CP}_{\mathrm{d}} \quad \cdots$ & -0.06 & 0.74 & 33.7 & 0.52 & 0.003 \\
\hline$\triangle \mathrm{ECM}$ yield $(\mathrm{kg} / \mathrm{d})$ & $\Delta \mathrm{CP}_{\mathrm{d}} \quad$ “ & 0.33 & 0.48 & 18.1 & 0.51 & 0.038 \\
\hline$\Delta$ protein yield $(\mathrm{g} / \mathrm{d})$ & $\Delta \mathrm{CP}_{\mathrm{d}} \quad \cdots$ & 11.9 & 19.3 & 22.0 & 18.2 & 0.021 \\
\hline$\Delta$ protein yield $(\mathrm{g} / \mathrm{d})$ & $\Delta C P_{d}(\mathrm{~g} \mathrm{CP} / \mathrm{d})$ & 7.0 & 0.108 & 41.0 & 15.8 & $<0.001$ \\
\hline $\begin{array}{l}\Delta \text { protein content } \\
(\mathrm{g} / \mathrm{kg})\end{array}$ & $\Delta \mathrm{ME}_{\mathrm{d}}(\mathrm{MJ} / \mathrm{d})$ & -0.084 & 0.071 & 24.9 & 0.59 & 0.013 \\
\hline
\end{tabular}

$\Delta \mathrm{CP}_{\mathrm{c}}=$ change in concentrate $\mathrm{CP}, \Delta \mathrm{CP}_{\mathrm{d}}=$ change in diet $\mathrm{CP}, \mathrm{ECM}=$ energy corrected milk yield

Table 26. Non-linear regressions between change in RSM or ME intake and response of milk or protein yield or protein content: $\mathrm{Y}=\mathrm{a}^{*}\left(1-\mathrm{e}^{-\mathrm{bx}}\right)$.

\begin{tabular}{|c|c|c|c|c|c|c|}
\hline $\begin{array}{l}\text { Dependent } \\
\text { variable Y }\end{array}$ & $\begin{array}{l}\text { Independent } \\
\text { variable X }\end{array}$ & a & b & R2 & S.E. & $\begin{array}{r}\text { Significance } \\
(\mathrm{P} \text {-value })\end{array}$ \\
\hline$\Delta$ milk yield $(\mathrm{kg} / \mathrm{d})$ & $\Delta \mathrm{RSM}(\mathrm{kg} / \mathrm{d})$ & 2.41 & 0.523 & 23.9 & 0.55 & 0.019 \\
\hline$\triangle \mathrm{ECM}(\mathrm{kg} / \mathrm{d})$ & $\Delta \mathrm{RSM} \quad “$ & 2.37 & 0.520 & 23.6 & 0.49 & 0.016 \\
\hline$\Delta$ protein yield $(\mathrm{g} / \mathrm{d})$ & $\triangle \mathrm{RSM} \quad “$ & 84.21 & 0.602 & 34.3 & 16.7 & 0.004 \\
\hline$\Delta$ protein content $(\mathrm{g} / \mathrm{d})$ & $\Delta \mathrm{ME}(\mathrm{MJ} / \mathrm{d})$ & 0.61 & 0.412 & 25.7 & 0.59 & 0.012 \\
\hline
\end{tabular}


tial equation. The responses in terms of milk yield to changes in the quantity of RSM were:

Change in RSM

supplement

$\mathrm{kg} / \mathrm{DM} /$ day $\quad 0-0.5 \quad 0-1.0 \quad 0-1.5 \quad 0-2.0$

Increase in milk

$\begin{array}{lllll}\text { yield, } \mathrm{kg} & 0.55 & 0.98 & 1.31 & 1.56\end{array}$

When the response in terms of milk production was calculated against the increase in crude protein

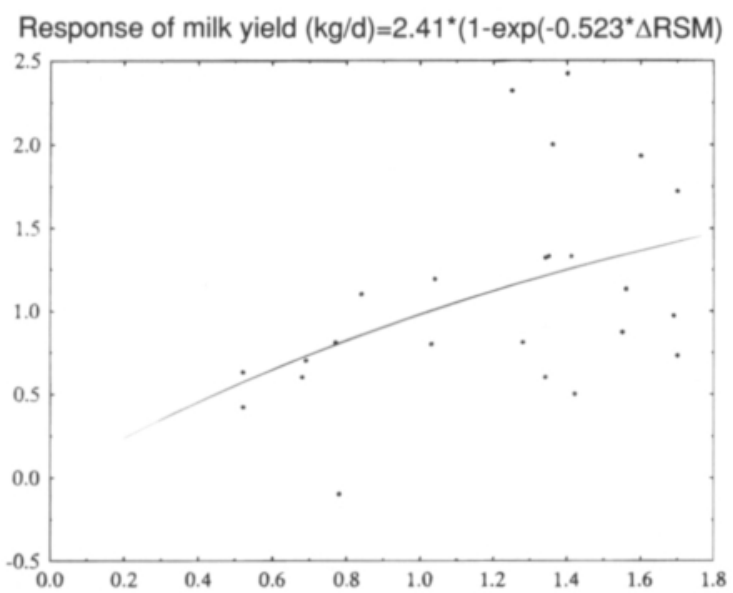

Fig. 1. Response of milk yield on the increase in RSM intake (kg milk per $\mathrm{kg}$ RSM DM)

Response of milk protein yield

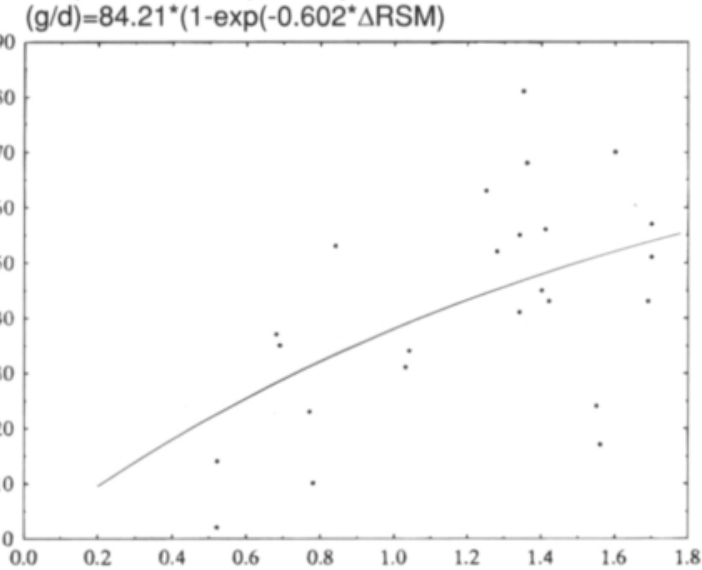

Fig. 3. Response of protein yield on the increase in RSM intake ( $\mathrm{g}$ protein per $\mathrm{kg}$ RSM DM) content of the concentrate, the response averaged $0.28 \mathrm{~kg}$ milk for each change in the crude protein content of $10 \mathrm{~g}$ in one $\mathrm{kg}$ concentrate (Table 25). Compared to corresponding responses reported in other studies, where the protein supplement has usually been soybean meal (Table 23 , mean 0.22 ), the responses to RSM were slightly greater in the present study. ThOMAS and RAE (1988) reported responses of 0 to $0.51 \mathrm{~kg}$ milk per a $10 \mathrm{~g}$ increase in $\mathrm{CP}$ in the concentrate, with soybean meal used as

Response of energy corrected milk yield

$(\mathrm{kg} / \mathrm{d})=2.366^{*}\left(1-\exp \left(-0.520^{*} \Delta \mathrm{RSM}\right)\right.$

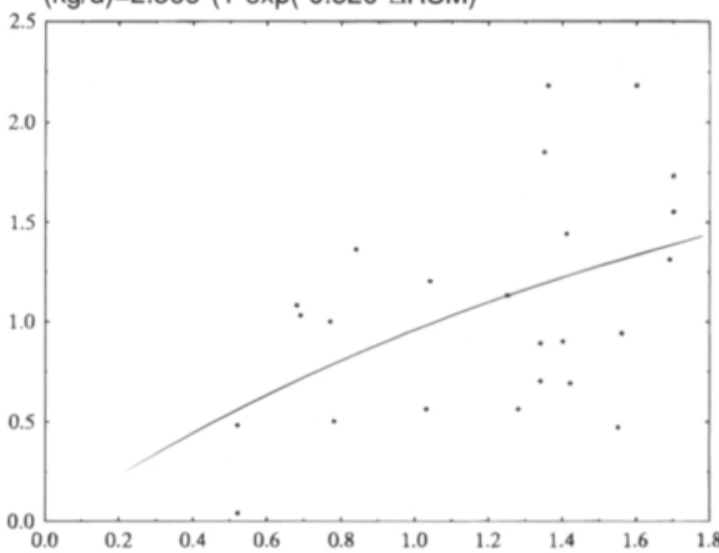

Fig. 2. Response of energy corrected milk yield (ECM) on the increase in RSM intake ( $\mathrm{kg}$ ECM per $\mathrm{kg}$ RSM DM)

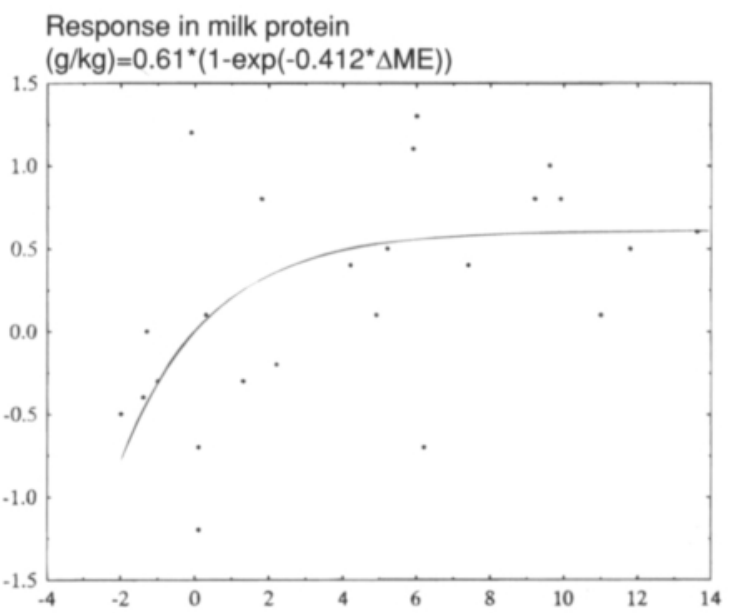

Fig. 4. Response of protein content on the increase in ME intake $(\mathrm{g} / \mathrm{kg}$ per $\mathrm{MJ} \mathrm{ME})$ 
the protein supplement.

A change in CP content of the concentrate or of the whole diet (Table 25) gave the highest determination coefficient for a change in milk yield. For both ECM and protein yield the best models were obtained with a change in RSM intake. The change in protein content of milk was explained by a change in the total metabolisable energy (ME) (Table 25), or by changes in the intake of RSM and ME from other feeds (Table 27).

The change in milk protein content was $0.07 \mathrm{~g} / \mathrm{kg}$ per $1 \mathrm{MJ}$ ME. A similar positive effect has been found in many studies (ETTALA 1976, EMERY 1978, SPÖRNDLY 1986, 1989). In the present study the effect was, however, markedly greater than that reported by EMERY (1978) and SPÖRNDLY (1989), who calculated responses of 0.036 and $0.03 \mathrm{~g} / \mathrm{kg}$ for each additional MJ of ME. In terms of protein content the corresponding reaction to the increase in energy concentration of the diet (MJ ME $/ \mathrm{kg}$ DM) was $5.3 \mathrm{~g} / \mathrm{kg}\left(\mathrm{R}^{2}=23.1 \%, \mathrm{P}=0.02\right)$. This increase was much greater than that of 1.0 reported by SPÖRNDLY (1989).

The ME concentration of the diet had either a slightly negative effect, or none at all, on the milk or protein yield. In contrast, SPÖRNDLY (1989) reported a highly significant positive effect of energy concentration on milk yield. The negative or zero effect in the present study is attributable to the experimental design, which was based on giving the cows a fixed quantity of concentrate: using RSM instead of grain decreased the ME- concentration of the concentrate mixture, and with increased intake of silage the calculated energy concentration was also diluted. SPÖRNDLY's data was based on feeding trials where concentrate rations were based on milk yield, and hay and straw, in addition to silage, were the sources of roughage. Thus the higher concentrate intake was based on higher milk production, with the result that the energy concentration of the diet increased.

In the present study the effect of forage intake on milk production was not statistically significant, although a slight positive effect was observed. ETTALA (1976) and SPÖRNDLY (1989) reported significant negative effects of the proportion of dietary roughage on milk yield. That, again, can be explained in terms of the data. Feeding concentrate at a constant rate, with high quality silage as almost the only forage, is not comparable to feeding concentrate according to yield, when the intake of roughage will be reduced as that of concentrate increases.

The effect of feed protein supplements on milk yield is partly attributable to increased energy intake (due to increased feed intake and digestibility, or only the latter) and partly to the (additional) protein supply itself. This "'protein factor" may increase protein synthesis in the rumen, as well as increase the flow of amino acid to the duodenum, or improve the quality of the amino acid mixture absorbed. Rumen microbes can benefit from amino acids introduced to the rumen (BEN-GHEDALIA et al. 1978), and the inclusion of mixtures of branched-

Table 27. Linear multiple regressions estimating response in milk yield and protein content: $Y=a+b_{1} X_{1}+b_{2} X_{2}\left(X_{1}=\right.$ change in $\mathrm{RSM}$ intake; $\mathrm{X}_{2}=$ change in $\left.\mathrm{ME}_{\text {TOTAL }}-\mathrm{ME}_{\mathrm{RSM}}\right)$.

\begin{tabular}{|c|c|c|c|c|c|c|c|}
\hline $\begin{array}{l}\text { Dependent } \\
\text { variable Y }\end{array}$ & a & $b_{1}$ & $b_{2}$ & $\mathrm{R}^{2}$ & S.E. & \multicolumn{2}{|c|}{$\begin{array}{l}\text { Significance } \\
\text { (P-value) }\end{array}$} \\
\hline$\Delta$ milk yield $(\mathrm{kg} / \mathrm{d})$ & 0.17 & 0.74 & -0.003 & 13.9 & 0.57 & 0.08 & 0.91 \\
\hline$\Delta \mathrm{ECM}$ yield $(\mathrm{kg} / \mathrm{d})$ & 0.20 & 1.01 & 0.03 & 34.4 & 0.48 & 0.007 & 0.16 \\
\hline$\Delta$ protein yield $(\mathrm{g} / \mathrm{d})$ & 5.3 & 41.0 & 1.23 & 42.0 & 16.5 & 0.002 & 0.12 \\
\hline$\Delta$ protein content $(\mathrm{g} / \mathrm{kg})$ & -0.14 & 0.89 & 0.07 & 32.0 & 0.62 & 0.05 & 0.03 \\
\hline
\end{tabular}


chain volatile fatty acids (derivatives of leucine valine, isoleucine and proline) has increased the milk production of dairy cows (PAPAS et al. 1984, PEIRCE-SANDNER et al. 1985).

In the present data of 24 observations, the increase in energy-corrected milk (ECM) yield averaged $1.07 \mathrm{~kg} / \mathrm{day}$, when the increase in $\mathrm{ME}$ intake averaged 4.37 MJ/day. Assuming 5.3 MJ $\mathrm{ME} / \mathrm{kg} \mathrm{ECM}$, the increased energy intake covered $77 \%$ of the growing energy requirement for increased production, when the daily RSM ration was increased from zero to $1.2 \mathrm{~kg}$ DM. Under these circumstances the protein factor covers $23 \%$ of the increase in milk production. Calculated in a similar way, the proportion of protein in the increased milk yield was $19 \%$ according to SMALL and GORDON (1990) and 66\% according to MAYNE and GORDON with high concentrates (10 kg/day). With low concentrates $(7 \mathrm{~kg} /$ day $)$ the supplementary protein had no positive effect. On the contrary, MAYNE and GORDON (1985) reported a stronger reaction to the supplementary protein in the low and medium concentrate diets, but this applies perhaps only to cases where the total food intake is restricted. The above mentioned ME requirement for milk production, $5.3 \mathrm{MJ}$ or $0.19 \mathrm{~kg}$ milk/ MJ ME, is theoretical. In practical feeding situations rates of 0.09 to $0.11 \mathrm{~kg}$ milk per MJ ME increase in the diet have been reported (GORDON 1984). The protein supplementation of the diet is likely to have affected the partitioning of food energy in the body, increasing energy mobilisation from tissue.

\subsection{Effect of protein protection on milk yield and protein content}

The effect of protein protection was compared in experiment 1-3 and 5 (Appendix 3). The effect of treatment on the degradation of protein and AAT values is presented in Tables 16 and 17. In trial 2 the treatment of RSM (Öpex heat-moisture treatment) had a significant positive effect on milk yield. In experiment 1 and 3 no such effect was observed, and in experiment 5 the treatment of RSM decreased milk yield, although not statistic- ally significantly.

Table 28 contains a review of some experiments with silage-based feeding having been supplemented by treated protein. In two experiments the milk yield increased significantly after the supplement had been treated with formaldehyde (FA) or heat, viz. REES and RowLINSON (1983) treated SBM with FA, and BERTILSSON (1991) used heat-treated RSM. In nine other experiments, however, no significant effect has been demonstrated. Although the protection of protein for high yielding ruminants is accepted in theory, only few experiments have produced data to support the procedure, e.g. VÉRITÉ and JOURNET (1977) supplemented a restricted maize diet with an SBM-RSM mixture treated with FA, and FALDET and SATTER (1991) used heat-treated full-fat soybeans. In the last mentioned experiment heating reduced the amount of antinutritional agents in SBM (e.g. trypsin inhibitors), and this was confounded by reduced degradability. KAUFMANN and LOUPPING (1979) demonstrated that SBM treated with FA had an effect on milk and protein yield, but in their experiment the confounding factor was the protein level. Crude protein content of the whole diet varied in the control group from $14.5 \%$ to $15.9 \%$, and in the test group from $18.6 \%$ to $19.2 \%$.

The objective of protein protection was to prevent the degradation of amino acids in the feed by microbes in the rumen, thereby increasing the flow of amino acids to the duodenum. For several reasons the desired effect is not always achieved (ТноMAS and RAE 1988). There is evidence to suggest that microbes in the rumen require preformed amino acids. Overprotection of feed protein may result in a shortage of degradable nitrogen and a shortage of amino acids for microbes in the rumen. PIATKOWSKI and VoIGT (1990) reported that raising the proportion of UDP in the feed protein decreases the efficiency of microbial synthesis per energy unit, which partly compensates the increased flow of amino acids to the duodenum. THOMAS and RAE (1988) concluded that dietary amino acid supplements should be rumen degradable rather than protected. 
Table 28. Effect of degradability of protein supplements on the performance in dairy cows on silage/hay based feeding (a review).

\begin{tabular}{|c|c|c|c|c|c|c|c|c|}
\hline \multirow{2}{*}{$\begin{array}{l}\text { Source and } \\
\text { treatment } \\
\text { of conc. mixt. }\end{array}$} & \multicolumn{2}{|c|}{$\mathrm{CP}, \%$ in $\mathrm{DM}$} & \multicolumn{2}{|c|}{ Intake, $\mathrm{kg} \mathrm{DM} / \mathrm{d}$} & \multirow{2}{*}{$\begin{array}{l}\text { Milk } \\
\text { yield } \\
(\mathrm{g} / \mathrm{kg})\end{array}$} & \multirow{2}{*}{$\begin{array}{l}\text { Milk } \\
\text { fat } \\
(\mathrm{g} / \mathrm{kg})\end{array}$} & \multirow{2}{*}{$\begin{array}{l}\text { Milk } \\
\text { protein }\end{array}$} & \multirow{2}{*}{$\begin{array}{l}\text { Live } \\
\text { weight } \\
\text { change }\end{array}$} \\
\hline & $\begin{array}{l}\text { Concen- } \\
\text { trate }\end{array}$ & Forage & $\begin{array}{l}\text { Concen- } \\
\text { trate }\end{array}$ & $\begin{array}{l}\text { Forage } \\
(\mathrm{kg} / \mathrm{d})\end{array}$ & & & & \\
\hline \multicolumn{9}{|l|}{ SYrJĀLĀ et al. (1978) } \\
\hline $9.6 \%$ SMP & 16.4 & 14.9 & 8.1 & 5.8 & 18.6 & 47.5 & 35.6 & \\
\hline $8.2 \%$ FA-SMP & 15.9 & 14.9 & 6.6 & 5.9 & 17.6 & 43.5 & 32.9 & \\
\hline \multicolumn{9}{|l|}{ RAE et al. (1983) } \\
\hline $9.1 \%$ RSM & & & 9.4 & 9.4 & 32.4 & 3.93 & 2.97 & \\
\hline $9.1 \%$ FA-RSM & & & 9.5 & 9.5 & 31.2 & 4.06 & 2.94 & \\
\hline \multicolumn{9}{|c|}{ REES \& ROWLINSON, (1983) } \\
\hline $16 \%$ SBM & & & 10.0 & 7.5 & $26.9 \mathrm{a}$ & 38.6 & $34.4 \mathrm{a}$ & \\
\hline $16 \%$ FA-SBM & & & 9.7 & 7.4 & $28.5 b$ & 38.1 & $32.0 \mathrm{~b}$ & \\
\hline \multicolumn{9}{|c|}{ CAstLe \& Watson, (1984) } \\
\hline $16.7 \%$ SBM & 17.4 & 16.3 & 6.4 & 8.8 & 23.9 & 37.5 & 31.0 & -0.14 \\
\hline $16.7 \%$ FA-SBM & 17.4 & 16.3 & 6.4 & 9.3 & 23.8 & 37.7 & 30.9 & -0.02 \\
\hline \multicolumn{9}{|l|}{ MORGAN (1985) } \\
\hline $8.2 \% \mathrm{SBM}$ & 15.2 & 14.0 & 7.8 & 9.1 & 18.8 & 36.9 & 33.2 & +0.26 \\
\hline $8.2 \%$ FA-SBM & 15.0 & 14.0 & 7.8 & 9.1 & 19.6 & 38.0 & 32.3 & +0.17 \\
\hline $24.5 \%$ SBM & 21.6 & 14.0 & 7.8 & 8.9 & 20.3 & 37.5 & 32.6 & +0.31 \\
\hline $\begin{array}{l}12 \% \text { FA-SBM } \\
+4.3 \% \text { SBM }\end{array}$ & 19.6 & 14.0 & 7.8 & 9.1 & 20.7 & 37.3 & 31.6 & +0.31 \\
\hline \multicolumn{9}{|l|}{ GORDON (1987) } \\
\hline $23.3 \%$ SBM & 21.4 & 15.6 & 7.2 & 26.6 & 36.9 & 30.6 & -0.39 & \\
\hline $10 \%$ FA-SBM & 21.9 & 15.6 & 7.2 & 27.3 & 37.1 & 30.6 & -0.31 & \\
\hline$+14.6 \%$ SBM & & & & & & & & \\
\hline \multicolumn{9}{|c|}{ ROBINSON \& KENNELLY (1988) } \\
\hline $24.7 \%$ RSM & 18.9 & 14.6 & 7.8 & 10.5 & 19.6 & 40.1 & 34.4 & \\
\hline $11.7 \%$ CGM & 19.6 & 14.6 & 7.9 & 10.8 & 20.2 & 40.7 & 34.3 & \\
\hline \multicolumn{9}{|l|}{ SLOAN et al. (1988) } \\
\hline $15 \%$ SBM & 16.7 & 12.2 & 9.2 & 8.7 & 26.1 & 39.7 & 34.5 & \\
\hline $10 \% \mathrm{FM}$ & 16.7 & 12.2 & 9.3 & 8.6 & 26.3 & 36.4 & 34.7 & \\
\hline \multicolumn{9}{|l|}{ GARNSWORTHY (1989) } \\
\hline $\begin{array}{l}7.5 \% \text { SBM+ } \\
1.3 \% \text { urea }\end{array}$ & 18.0 & 8.5 & 9.1 & 4.9 & 22.5 & $40.4 \mathrm{a}$ & 28.7 & -0.10 \\
\hline $5.5 \% \mathrm{FM}+$ & 17.6 & 8.5 & 9.1 & 4.9 & 23.9 & $32.4 \mathrm{~b}$ & 28.0 & -0.03 \\
\hline $\begin{array}{l}9 \% \text { SBM } \\
\text { SMALL \& GORDON (19 }\end{array}$ & \multicolumn{7}{|c|}{ SMALL \& GORDON (1990) } & \\
\hline $23.7 \%$ SBM & 20.6 & 18.7 & 6.8 & 9.4 & 26.2 & 40.0 & 30.2 & \\
\hline $23.9 \%$ FA-SBM & 20.5 & 18.7 & 6.8 & 9.7 & 26.7 & 37.6 & 30.0 & \\
\hline \multicolumn{9}{|l|}{ CoDY et al. (1990) } \\
\hline $23 \%$ SBM & 21.0 & 15.7 & 7.0 & 8.4 & 23.0 & 36.0 & 30.0 & \\
\hline $\begin{array}{l}8 \% \mathrm{FM}+ \\
12 \% \mathrm{SBM}\end{array}$ & 21.8 & 15.7 & 7.0 & 8.7 & 23.6 & 34.5 & 31.3 & \\
\hline \multicolumn{9}{|l|}{ BERTILSSON (1990) } \\
\hline $8 \%$ RSM & 14.3 & 14.1 & 8.2 & 10.4 & $24.9^{a}$ & $47.3^{\mathrm{a}}$ & 32.8 & -0.07 \\
\hline $8 \%$ HT-RSM & 14.3 & 14.1 & 8.0 & 10.5 & $27.1^{\mathrm{b}}$ & $45.1^{\mathrm{b}}$ & 31.7 & -0.10 \\
\hline $25 \%$ RSM & 18.8 & 14.1 & 8.0 & 10.4 & 27.1 & 45.3 & 32.1 & -0.09 \\
\hline $25 \%$ HT-RSM & 19.0 & 14.1 & 8.6 & 10.5 & 27.9 & 43.7 & 32.3 & -0.06 \\
\hline \multicolumn{9}{|l|}{ HUHTANEN (1991) } \\
\hline $17.6 \%$ RSM & 17.5 & 18.2 & 7.1 & 10.0 & 24.5 & 43.3 & 32.2 & +0.04 \\
\hline $17.6 \%$ HT-RSM & 17.4 & 18.2 & 7.0 & 10.1 & 24.7 & 42.9 & 32.3 & +0.05 \\
\hline HUHTANEN et al. (199 & & & & & & & & \\
\hline $17.6 \%$ DDS & 20.2 & 14.2 & 7.1 & 10.6 & 24.0 & 39.7 & 29.1 & +0.13 \\
\hline $17.6 \%$ FA-DDS & 20.9 & 14.2 & 7.0 & 10.7 & 24.5 & 40.0 & 29.3 & +0.23 \\
\hline
\end{tabular}

$\mathrm{CGM}=$ corn gluten meal; DDS = dried distiller's grain; FA = formaldehyde treatment, FM = fish meal; HT = heat treatment; RSM

$=$ rapeseed meal, $\mathrm{SBM}=$ soybean meal; $\mathrm{SMP}=$ skim milk powder

a.b $(\mathrm{P}<0.05)$ 
Chemical or heat treatment of feed protein can affect the availability of amino acids, although no impairment in digestibility is observed. Lysine, tyrosine and cystine are most sensitive to formaldehyde (AsHEs et al. 1984).

Cows with negative energy balances may respond more strongly to protected protein (VÉRITÉ and Journet 1977, AHrAR and SChINGOETHE 1979, ØRSKOV et al. 1981, KAIM et al. 1987). In BERTILSSON's (1991) experiment, where heat treatment of RSM increased milk yield, restricted feeding resulted in weight loss by the cows. With high quality grass silage feeding ad libitum there has been no advantage in decreasing the degradability of the CP in the supplementary concentrate (CASTLE and WATSON 1984, GORDON and UNSWORTH 1986, GoRDON 1987, SMALL and GoRDON 1990).

In the present study experiments 1 and 2 were continuous trials, the others being changeover trials by design, in which the length of the period was either 25 or 28 days, and the results of the last two weeks were calculated. Perhaps the apparent lack of response to treated RSM was due to the changeover design of the experiment. CASTLE and WATSON (1984) raised the same question, when FAtreated SBM failed to elicit any response in dairy cows in a changeover trial. However, in an earlier trial of the same design and protein supplements (SBM, groundnut cake and single cell protein) significant differences were noticed by CASTLE and
WATSON (1976). They concluded that an early stage of lactation, when diets were evaluated with a high degree of precision, and small groups of experimental animals were used, the changeover design can play a vital part in providing consistently reliable results.

Now it appears that the changes in glucosinolate content during different experiments may explain the results of the present study. The total glucosinolate content in the untreated RSM was the highest in experiment 2 (49 $\mu$ moles), followed by 28 $\mu$ moles (Exp. 3) and $13.5 \mu$ moles (Exp. 5). The Öpex treatment did have an effect on milk yield in experiment 2, but not in the other experiments. The difference in protein degradability between untreated and Öpex-treated RSM was minor in experiment 3 , being greater in experiment 5 . The most likely effect of Öpex treatment was the reduction in glucosinolate content. As the RSM used by BERTILSSON (personal communication 1992) did not differ in glucosinolate content, his results must have been influenced by other factors.

\subsection{Goitrin content of milk}

The goitrin (5-vinyl-oxazolidine-2-thione) content of milk in experiments 1 to 3 is presented in Table 29. The heat treatment of RSM, or the removal of glucosinolates by ferrous sulphate had the most noticeable effect on the goitrin content of milk. The

Table 29. Goitrin content in milk in the experiments 1-3.

\begin{tabular}{|c|c|c|c|c|c|c|c|}
\hline \multirow{2}{*}{\multicolumn{2}{|c|}{$\begin{array}{l}\text { Exp.RSM } \\
\text { no. }\end{array}$}} & \multicolumn{2}{|c|}{ Intake of RSM (kg/d) } & \multicolumn{2}{|c|}{ Goitrin in milk $(\mu \mathrm{g} / \mathrm{l})$} & \multirow{2}{*}{\multicolumn{2}{|c|}{$\begin{array}{l}\text { Goitrin output/ } \\
\text { progoitrin intake, \% } \\
\text { Period1 Period2 }\end{array}$}} \\
\hline & & Periodl & Period2 & Period1 & Period2 & & \\
\hline \multirow[t]{3}{*}{1} & 0-RSM & 1.21 & 0.59 & 39.4 & 9.0 & 0.064 & 0.026 \\
\hline & 0-RSM & 1.93 & 0.93 & 55.6 & 18.2 & 0.052 & 0.030 \\
\hline & 00-RSM-Heated & 1.20 & 0.57 & 4.6 & 1.0 & 0.027 & 0.008 \\
\hline \multirow[t]{2}{*}{2} & 0-RSM & 1.12 & 1.04 & 21.6 & 12.7 & 0.016 & 0.009 \\
\hline & 0-RSM-Öpex & 1.14 & 1.16 & 13.5 & 9.8 & 0.031 & 0.020 \\
\hline \multirow[t]{4}{*}{3} & 00-RSM-Öpex & 0.84 & & 7.9 & & 0.040 & \\
\hline & 00-RSM-Öpex & 1.69 & & 22.8 & & 0.059 & \\
\hline & 0 -RSM & 1.70 & & 75.3 & & 0.080 & \\
\hline & 00-RSM-FeSO & 1.71 & & 9.0 & & 0.046 & \\
\hline
\end{tabular}


effect of variety could not be compared, because in experiment 3 untreated single-low RSM was used in contrast to treated double-low RSM. Treating RSM reduced the goitrin content of milk significantly in experiments 1 and $2(\mathrm{P}<0.05)$, and in experiment 3 there was a significant difference between untreated 0-RSM and all other RSM supplements.

In experiment 2 a significant difference in goitrin content between the samples taken six weeks apart was also observed. The intake of RSM changed very little during these periods. It is possible that the cows adapted to some extent to the progoitrin in the feed. In experiment 1 the amount of RSM was reduced during period 2 , which accounts for the lower goitrin content. However, the ratio between the output of goitrinous milk and the intake of goitrin in the form of progoitrin in the feed was significantly lower during the latter period in both experiments. This ratio varied between $0.009 \%$ and $0.064 \%$, being lower than that reported by VIRTANEN et al. $(0.05 \%)(1959)$, and by BACHMANN et al. (1985), the latter having reported a value of $0.1 \%$. The observations of ARSTILA et al. (1969) do not support the adaptation theory, as the goitrin content of milk actually increased at fixed feeding levels. On the other hand, their observation period was five days only. Hence their results may be explained in terms of the relatively long biological halflife of goitrin in the body.

In the present study the goitrin level of milk was still high in experiment 3 with a diet of untreated single-low RSM, although the glucosinolate content of RSM was lower than in experiments 1 and 2. ARSTILA et al. (1969) reported similar goitrin contents. RAURAMAA (1983) measured goitrin contents of 2-31 $\mu \mathrm{g}$ per litre of milk supplied by 37 dairies throughout Finland, but detected goitrin in only 19 of a total of 224 samples. BACHMANN et al. (1985) measured goitrin contents as high as $700 \mu \mathrm{g}$ per litre of milk when $1 \mathrm{~kg} / \mathrm{d}$ RSM was given in the feed. The intake of goitrin was $46.2 \mu \mathrm{M} /$ day. With an RSM supplement of $0.5 \mathrm{~kg} /$ day the goitrin content of milk was $163 \mu \mathrm{g} / \mathrm{l}$, and with $0.1 \mathrm{~kg}$ of RSM, the goitrin content of milk was $38 \mu \mathrm{g} / \mathrm{l}$. The total glucosinolate content of RSM was about 80 $\mu$ moles/g (assuming the progoitrin content was $60 \%$ ). In the present study the highest goitrin content, $75.3 \mu \mathrm{g} / 1$ in experiment 3 , was measured with $2.2 \mathrm{~g}$ of progoitrin $(5.1 \mu \mathrm{M} /$ day $)$ in RSM. The variations in the goitrin content of milk are partly attributable to the amount of progoitrin in the feeds and partly to the increased efficiency of goitrin transfer from feed to milk.

Goitrin inhibits the synthesis of the thyroid hormone even when the daily doses do not affect the relative radioiodine uptake of the thyroid (ARSTILA et al. 1969), the rate of $10 \mu \mathrm{g} / \mathrm{l}$ being high enough to produce thyroid enlargement in rats. The quantity needed by man is unknown (ARSTILA et al. 1969). In England it is estimated that the intake of progoitrin from vegetables varies from 5 to $26 \mu$ moles/d, and that 5 per cent of the population consumes more than $117 \mu$ moles/d during the winter. Yet there is no record in the United Kingdom of any diet-related (Brassica) thyroid dysfunction in the population (HEANEY and FENWICK 1985).

In Finland the new double zero varieties of RSM contain less than $10 \mu$ moles of glucosinolates per gram of fat-free matter. A $16 \%$ mixture of such RSM in a concentrate (1.3-1.6 kg/d) resulted in goitrin contents of 3.5 to $6.4 \mu \mathrm{g} / \mathrm{l}$ in the milk of six cows (TUORI and SYRJÄLÄ-QVIST 1992, unpublished). As the daily milk consumption in Finland averages less than 11 per person, goitrin intake through milk products cannot constitute any serious risk of thyroid dysfunction in the Finnish population.

\subsection{DCP and AAT protein evaluation systems in milk production}

\subsubsection{Comparison of DCP and AAT systems}

The DCP and AAT-PBV systems were compared by calculating different parameters for the utilization of protein in milk production. The data was based on seven milk production trials (Table 12), in which the cows were fed various protein supplements in different quantities and degrees of degradability. A total of 34 observations, covering the 
feeding of groups of 4 to 8 cows, provided the mean data.

Table 30 contains the figures for average protein intake andutilisation in different experiments calculated in terms of DCP and AAT. The standard error illustrates the variations between feeding groups. The variation coefficient (s.e./mean) for the utilization of DCP was $8.0 \%$ and that for AAT was $4.2 \%$. Measured this way the AAT value of the feeds provided a better basis for estimating the utilization of protein in different experiments. When milk protein yield was explained in terms of protein and ME intake (the effect of protein intake was eliminated from ME intake), the standard error and determination coefficient were $18.5 \mathrm{~g}$ and $82.8 \%$ using AAT, or $16.4 \mathrm{~g}$ and $91.6 \%$ using DCP as the protein measurement (Table 32).

THUEN and VIK-Mo (1985) and VIK-Mo (1985) regressed milk yield against protein intake, which had been calculated with different methods. There, again, the coefficient of variation was higher using DCP than AAT or the French PDI method.

In practical diet formulation protein can be saved by using new protein evaluation methods, whereby the degraded protein in the rumen can be of lower quality than the undegraded protein. The importance of degradation may have been overestimated, especially when feeding was based on high quality grass silage, and the expectations of increased milk production due to new systems may be too high. In a Norwegian experiment two kinds of comparisons were made: on the one hand a constant DCP level with two varying AAT levels (fish meal at two stages of degradation), and on the other hand a constant AAT level with two different DCP levels (less degraded fish meal versus more degraded fish meal plus SBM). The results did not fully support the new system (VoLDEN et al. 1992).

\subsubsection{Effect of corrections of AAT-PBV values of RSM and other feeds}

The AAT-values above were calculated without correction for particle loss. Further, the unavailable energy of fermentation acids in silage, or the available energy in lactic acid (CHAMBERLAIN 1987), or the rumen degradable feed proteins available to microbes (DEMEYER and VAN NEVEL 1979) were

Table 30. The average intake of feed protein in different experiments and utilization of AAT ${ }^{1)}$ and DCP in milk production.

\begin{tabular}{|c|c|c|c|c|c|c|c|c|c|}
\hline & \multicolumn{2}{|c|}{ Experiment } & \multirow[b]{2}{*}{3} & \multirow[b]{2}{*}{$4 a$} & \multirow[b]{2}{*}{$4 b$} & \multirow[b]{2}{*}{5} & \multirow[b]{2}{*}{6} & \multirow[b]{2}{*}{7} & \multirow[b]{2}{*}{ S.E. } \\
\hline & 1 & 2 & & & & & & & \\
\hline $\mathrm{n}$ & 4 & 2 & 5 & 4 & 4 & 7 & 6 & 2 & \\
\hline \multicolumn{10}{|l|}{ Intake $(\mathrm{g} / \mathrm{d})$} \\
\hline $\mathrm{CP}$ & 2377 & 2530 & 2830 & 2155 & 2312 & 3056 & 3044 & 3056 & 199.8 \\
\hline DCP & 1728 & 1853 & 2164 & 1614 & 1725 & 2399 & 2348 & 2284 & 175.8 \\
\hline AAT & 1456 & 1357 & 1273 & 1095 & 1159 & 1449 & 1335 & 1361 & 58.8 \\
\hline PBV & -67 & 213 & 715 & 325 & 337 & 643 & 802 & 799 & 147.8 \\
\hline EPD (\%) & 57.6 & 67.5 & 79.8 & 79.6 & 75.7 & 78.0 & 84.1 & 79.2 & 2.28 \\
\hline $\begin{array}{l}\text { Protein yield } \\
(\mathrm{g} / \mathrm{d})\end{array}$ & 747 & 724 & 754 & 584 & 598 & 787 & 785 & 787 & 28.7 \\
\hline \multicolumn{10}{|l|}{ Utilization ${ }^{2)}$} \\
\hline AAT & 0.68 & 0.71 & 0.84 & 0.79 & 0.74 & 0.74 & 0.82 & 0.79 & 0.032 \\
\hline DCP & 0.53 & 0.46 & 0.41 & 0.45 & 0.42 & 0.38 & 0.39 & 0.40 & 0.035 \\
\hline \multicolumn{10}{|c|}{$\mathrm{g}$ protein $/ \mathrm{kg} \mathrm{ECM}$} \\
\hline AAT & 43.7 & 41.8 & 36.4 & 38.9 & 42.8 & 42.1 & 37.2 & 39.8 & 1.80 \\
\hline DCP & 56.3 & 64.0 & 74.2 & 68.4 & 75.2 & 81.5 & 78.0 & 78.4 & 5.62 \\
\hline
\end{tabular}

\footnotetext{
1) Calculation of AAT/PBV-values: see footnote in Table 15

2) Utilization: milk protein/(protein intake-protein for maintenance)

S.E. is standard error of the estimate from the model: $y_{i j}=\mu+$ experiment $_{i}+e_{i j} ; n=34$
} 
not taken into account.

Table 31 shows the effect of corrections of the protein values of feeds in the experiment 5 . Loss of nitrogen, with particles escaping the nylon bag is fairly high for oat ca. $60 \%$. Correction (WEISBJERG et al. 1989) decreased the EPD value by 20 percentage points, increasing the AAT-value of oat by $19 \mathrm{~g}$ (27\%). Particle loss for RSM varied from $16 \%$ to $19 \%$ between Öpex-treated and untreated RSM. The correction decreased the EPD value by c. $10 \%$, increasing the AAT-value by $27 \mathrm{~g}$ and $25 \mathrm{~g}(16 \%$ and $19 \%$ respectively). In the earlier experiments the rate of particle loss with RSM was lower, only a few percentage points. The factors that may have an effect on particle loss include the rapeseed variety, the oil extraction processes and milling of the sample, and the pore size of the nylon bag.

Correcting the EPD value according particle loss is based on the assumption that the nitrogen in the small particles escaping from the bag is degraded at the same rate as the protein remaining in the bag. The degradation of protein in different soluble and insoluble fractions should be determined, for instance with the so-called Cornell system (CHALUPA 1992).

Decreasing the outflow rate from the rumen from 0.08 to 0.03 increased EPD value from $38 \%$ to 62 $\%$ on treated RSM and from $56 \%$ to $74 \%$ on

Table 31. Effect of some corrections on the EPD and AAT-PBV values of the feeds in the experiment 5.

\begin{tabular}{|c|c|c|c|c|c|c|c|c|}
\hline & Hay & Silage & Barley & Oat & RSM & TRSM & SBM & TSBM \\
\hline Micr.N correct. of EPD & 14.1 & 8.2 & & & & & & \\
\hline Water soluble $\mathrm{N}$ & & & 2.6 & 4.0 & 11.6 & 4.6 & 13.4 & 8.7 \\
\hline Particle loss of $\mathrm{N}$ & & & 18.7 & 59.6 & 18.9 & 15.7 & 11.1 & 11.3 \\
\hline EPD $^{\prime)} \quad(k=0.08)$ & 73.2 & 82.8 & 60.3 & 88.1 & 65.3 & 48.2 & 57.1 & 40.8 \\
\hline $\mathrm{EPD}^{122)}(\mathrm{k}=0.08)$ & 73.2 & 82.8 & 50.8 & 68.6 & 55.9 & 38.0 & 50.8 & 32.5 \\
\hline $\mathrm{EPD}^{122)} \quad(\mathrm{k}=0.03)$ & 84.5 & 92.4 & 73.2 & 81.4 & 73.9 & 61.6 & 73.2 & 59.5 \\
\hline AAT1 (system; k=0.08) & 73 & 72 & 111 & 71 & 130 & 172 & 183 & 242 \\
\hline PBV1 & -34 & 55 & -47 & 23 & 196 & 123 & 223 & 146 \\
\hline AAT3 $\quad(k=0.08)$ & 73 & 72 & 120 & 90 & 155 & 199 & 205 & 271 \\
\hline PBV3 & -34 & 55 & -60 & -4 & 159 & 84 & 192 & 104 \\
\hline AAT7 $\quad(k=0.08)$ & 76 & 73 & 123 & 95 & 167 & 207 & 219 & 279 \\
\hline PBV7 & -40 & 52 & -66 & -13 & 140 & 72 & 169 & 90 \\
\hline AAT12 (k=0.03) & 72 & 65 & 104 & 83 & 122 & 149 & 147 & 192 \\
\hline PBV12 & -31 & 68 & -39 & 4 & 204 & 153 & 270 & 213 \\
\hline AAT17 $(\mathrm{k}=0.03)$ & 103 & 94 & 145 & 116 & 147 & 173 & 175 & 218 \\
\hline PBV17 & -85 & 20 & -106 & -52 & 161 & 113 & 224 & 170 \\
\hline AAT18 $(\mathrm{k}=0.03)$ & 74 & 85 & 103 & 93 & 138 & 162 & 169 & 209 \\
\hline PBV18 & -28 & 43 & -29 & -4 & 183 & 139 & 243 & 193 \\
\hline
\end{tabular}

1) EPD with microbial-N correction for roughage (MICHLET-DOREAU \& OULD-BAH 1989)

2) Particle loss correction (WeISBJERG et al. 1990)

Explanations for the AAT values (see also Table 32):

- Efficiency of microbial protein synthesis $=20 \mathrm{~g} \mathrm{AAN} / \mathrm{kg}$ DCHO (AAT1, AAT3, AAT7, AAT12), $30 \mathrm{~g} / \mathrm{kg}$ (AAT17), (185-1.31*UDP\%)*DOM (AAT18);

- Particle loss correction for concentrates (AAT3, AAT7, AAT12, AAT17, AAT18)

- DCHO correction (AAT7, AAT12, AAT17) 
untreated RSM. AAT value decreased by $28 \%$ (Table 31). Higher values for outflow rate were measured by using mortanded straw marker or protein supplements, which produce more rumen indigestible particles. Lower values were measured for NDF, which presented the outflow of protein better (TAMmINGA et al.1989).

Using corrected digestible carbohydrate values obtained by calculating the microbial protein synthesis had only minor effect on the AAT-values of the feeds. In silage the AAT-value remained unchanged, when increased energy for microbes from rumen degradable protein was balanced with the loss of energy in fermentation acids. Table 31 also contains AAT-values calculated with a higher value for the efficiency of microbial protein synthesis (30 g AA-N/kg DCHO), or calculated with the formula devised by VoIGT and PIATKOWSKI (1991).

\subsubsection{Effect of corrections of AAT values on the} utilization of feed protein

Average protein utilization and its coefficient of variation was calculated after the above mentioned corrections or adjustments to AAT-values were made (Tables 32 and 34). In Table 33 milk protein yield has been regressed against the protein and energy intake. Energy intake (ME) is corrected by eliminating the effect of protein intake.

The correction for microbial-N contamination with the k-value of 0.08 gave roughage similar AAT values to those obtained with the k-value of 0.03 without microbial- $\mathrm{N}$ correction. The variation in protein utilization also stayed at the same level (Table 32).

Both particle loss correction and that of DCHO reduced the variation in utilization parameters. The

Table 32. Mean values and variation coefficients for utilization of feed protein using different correction for AAT $(y i j=\mu+$ experiment $\left.\mathrm{t}_{\mathrm{i}}+\mathrm{e}_{\mathrm{ij}} ; \mathrm{n}=34\right)$.

\begin{tabular}{|c|c|c|c|c|c|c|c|c|c|c|}
\hline \multirow{2}{*}{$\begin{array}{l}\text { Feed } \\
\text { protein }\end{array}$} & \multirow[b]{2}{*}{$\begin{array}{l}\mathrm{k} \text {-value } \\
\text { of rough- } \\
\text { age }^{2)}\end{array}$} & \multicolumn{4}{|c|}{ Assumptions for calculating the AAT } & \multirow{2}{*}{$\begin{array}{l}\text { Diet } \\
\text { EPD-\% }\end{array}$} & \multicolumn{2}{|c|}{$\begin{array}{l}\text { Utilization of } \\
\text { feed protein }\end{array}$} & \multicolumn{2}{|c|}{$\begin{array}{l}\text { Protein con- } \\
\text { version rate } \\
\mathrm{g} / \mathrm{kg} \mathrm{ECM}\end{array}$} \\
\hline & & TD.UDP & $\begin{array}{l}\text { Micr.N } \\
\text { corr. }\end{array}$ & $\begin{array}{l}\text { Particle } \\
\text { loss }\end{array}$ & $\begin{array}{l}\text { DCHO- } \\
\text { corr. } \\
\text { corr. }\end{array}$ & & Mean & $\mathrm{CV}^{4)}$ & $\begin{array}{l}\mathrm{g} / \mathrm{kg} \mathrm{H} \\
\text { Mean }\end{array}$ & $\mathrm{CV}$ \\
\hline DCP & & & & & & & 0.432 & 8.03 & 72.0 & 7.80 \\
\hline AAT1 ${ }^{1)}$ & 0.08 & 0.82 & + & - & - & 75.2 & 0.763 & 4.15 & 40.4 & 4.45 \\
\hline AAT2 & 0.03 & " & - & - & - & 75.7 & 0.767 & 4.24 & 40.1 & 4.54 \\
\hline AAT3 & 0.08 & $"$ & + & + & - & 70.1 & 0.693 & 3.57 & 44.4 & 3.87 \\
\hline AAT4 & 0.03 & $"$ & - & + & - & 70.5 & 0.697 & 3.67 & 44.1 & 3.95 \\
\hline AAT5 & 0.08 & “ & + & - & + & 75.2 & 0.716 & 3.91 & 43.0 & 4.24 \\
\hline AAT6 & 0.03 & $"$ & - & - & + & 75.7 & 0.719 & 3.35 & 42.7 & 4.27 \\
\hline AAT7 & 0.08 & $"$ & + & + & + & 70.2 & 0.659 & 3.32 & 46.7 & 3.72 \\
\hline AAT8 & 0.03 & $"$ & - & + & + & 70.5 & 0.661 & 3.57 & 46.6 & 4.03 \\
\hline AAT9 & 0.08 & $\mathrm{TU}=.07^{3)}$ & + & - & - & 75.2 & 0.809 & 5.10 & 38.2 & 5.30 \\
\hline AAT 10 & 0.08 & " & + & + & + & 70.2 & 0.678 & 4.14 & 45.5 & 4.59 \\
\hline
\end{tabular}

1) AAT1 is assumed to be according to the AAT-PBV system; ${ }^{2)}$ for concentrate feeds $k=0.08 ;{ }^{3)}$ TD.UDP $=($ UDP $\mathrm{TU}) / \mathrm{UDP} ;{ }^{4)} \mathrm{CV}=$ coefficient of variation (\%)

Corrections for AAT: Microbial-N correction for roughage (MICHALET-DOREAU \& OULD-BAH 1989); particle loss correction for concentrate feeds (WEISBJERG et al. 1990); DCHO-corr. for all feeds: DCHO + $0.50 *$ RDP - $0.75 *$ lactic acid - VFA, (NousIAINEN 1992). 
Table 33. Standard error and coefficient of variation of milk protein yield:

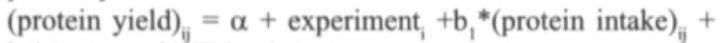
$\mathrm{b}_{2}{ }^{*}$ (corrected ME intake $)_{i j}+\mathrm{e}_{\mathrm{ij}}$.

\begin{tabular}{llll}
\hline $\begin{array}{l}\text { Protein } \\
\text { intake }\end{array}$ & $\mathrm{R}^{2}$ & $\begin{array}{l}\text { S.E. } \\
\text { of estimate }\end{array}$ & $\mathrm{CV}$ \\
\hline DCP & 91.6 & 16.4 & 2.24 \\
AAT1 & 82.8 & 18.5 & 2.54 \\
AAT2 & 81.8 & 18.8 & 2.58 \\
AAT3 & 84.9 & 18.3 & 2.51 \\
AAT4 & 84.3 & 18.6 & 2.55 \\
AAT5 & 85.1 & 16.8 & 2.35 \\
AAT6 & 84.1 & 17.0 & 2.33 \\
AAT7 & 87.4 & 16.4 & 2.25 \\
AAT8 & 86.5 & 16.9 & 2.32 \\
AAT9 & 82.2 & 19.4 & 2.65 \\
AAT10 & 86.7 & 17.7 & 2.43 \\
\hline
\end{tabular}

effect of changing the value of TD.UDP was unexpected. The constant value of 0.82 resulted in lower variations than with the estimated value of the equation TD.UDP $=($ UDP-TU $) / U D P$, where TU had the fixed value of 0.07 (Table 32). The value of TU should probably be determined for different feeds as HvelpLuND et al. (1992) have proposed, otherwise a constant value for TD.UDP is preferable.
The variation was further reduced as the value of protein synthesis efficiency increased, in addition to all the corrections (Table 34). The rumen outflow rate of 0.03 was used for all feeds. This rate is higher or close to the outflow rate of NDF or roughage particles reported in many studies (MÄKELÄ 1956, SETÄLÄ 1983, TAMMINGA et al. 1989, HuHTANEN and KHALILI 1991).

The efficiency of microbial protein synthesis per energy unit varies greatly (HVELPLUND and MADSEN 1985), especially by rising at a direct ratio with increased feeding levels (RoBINSON et al. 1985, SNIFFEN et al. 1987). The production level in the present data was moderate $(22.5 \mathrm{~kg}$ milk/day, intake $16.1 \mathrm{~kg} \mathrm{DM} /$ day). The proportion of AAT, calculated from the microbial mass, increased from $79 \%$ to $83 \%$ of total AAT intake when the value of efficiency was changed from 20 to $30 \mathrm{~g}$ microbial amino-N per $\mathrm{kg}$ DCHO (with $\mathrm{k}=0.03$ ). This may be too high a value for protein of microbial origin, although in some studies involving dairy cows with high milk yields, the proportion has been 70 to 80 per cent (Klusmeyer et al. 1990, Ferlay et al. 1992). All the same, the variation in protein utilization decreased.

Voigt and Piatkowski $(1990,1991)$ found a

Table 34. Mean values and variation coefficients for utilization of feed protein using different efficiencies of microbial protein synthesis

$\left(\mathrm{y}_{\mathrm{ij}}=\mu+\right.$ experiment $\left._{\mathrm{i}}+\mathrm{e}_{\mathrm{ij}} ; \mathrm{n}=34\right)$.

\begin{tabular}{|c|c|c|c|c|c|c|c|}
\hline \multirow{3}{*}{$\begin{array}{l}\text { Feed } \\
\text { protein }\end{array}$} & \multirow{3}{*}{$\begin{array}{l}\text { Efficiency of } \\
\text { micr. protein } \\
\text { synthesis, g } \\
\text { amino-N/kg DCHO }\end{array}$} & \multirow{3}{*}{$\begin{array}{l}\text { k-value } \\
\text { (all } \\
\text { feeds) }\end{array}$} & \multirow{3}{*}{$\begin{array}{l}\text { AAT } \\
\text { intake } \\
(\mathrm{g} / \mathrm{d})\end{array}$} & \multirow{2}{*}{\multicolumn{2}{|c|}{$\begin{array}{l}\text { Utilization } \\
\text { of feed protein }\end{array}$}} & \multicolumn{2}{|c|}{$\mathrm{g}$ protein $/ \mathrm{kg} \mathrm{ECM}$} \\
\hline & & & & & & \multirow[t]{2}{*}{ Mean } & \multirow[t]{2}{*}{$\mathrm{CV}$} \\
\hline & & & & Mean & $\mathrm{CV}$ & & \\
\hline AAT7 & 20 & 0.08 & 1311 & 0.659 & 3.32 & 46.7 & 3.72 \\
\hline AAT11 & 18 & 0.03 & 1190 & 0.869 & 3.29 & 35.4 & 4.07 \\
\hline AAT12 & 20 & 0.03 & 1289 & 0.776 & 2.94 & 39.7 & 3.62 \\
\hline AAT13 & 22 & 0.03 & 1388 & 0.701 & 2.70 & 43.9 & 3.29 \\
\hline AAT 14 & 24 & 0.03 & 1487 & 0.639 & 2.51 & 48.1 & 3.03 \\
\hline AAT15 & 26 & 0.03 & 1585 & 0.588 & 2.38 & 52.3 & 2.84 \\
\hline AAT 16 & 28 & 0.03 & 1684 & 0.544 & 2.28 & 56.6 & 2.69 \\
\hline AAT17 & 30 & 0.03 & 1783 & 0.506 & 2.22 & 60.8 & 2.58 \\
\hline AAT18 & & 0.03 & 1448 & 0.663 & 2.05 & 46.3 & 2.43 \\
\hline
\end{tabular}

Corrections: microbial-N for roughage, particle loss for concentrate feeds, DCHO for all feeds

${ }^{1)}$ Efficiency of microbial protein synthesis: (185-1.31*UDP\%)*DOM (VoIGT and PIATKOWSKI 1991) 
negative correlation between the proportion of UDP and the efficiency of microbial protein synthesis in the rumen. This may be caused by a decrease in the energy released in the rumen, or a decrease in the availability of amino acids and peptides to microbes. In the present study the dietary intake of AAT was calculated using the formula for microbial protein synthetized (MPS) of VolGT and PIATKOWSKI (1991):

$$
\text { MPS }=(185-1.31 * \text { UDP\% }) * \text { DOM }
$$

where DOM refers to digestible organic matter $(\mathrm{kg})$. The proportion of amino acid nitrogen was taken as 0.75 and digestibility as $\mathbf{0 . 8 5}$. For UPD the respective values were taken from the Nordic system. Variation coefficients for protein (AAT18) utilization are shown in Table 34.

The residual variance of the utilization of protein was significantly different $(\mathrm{P}<0.01)$ between AAT1 (Nordic system) and AAT18 (Rostock). However, when AAT intake was calculated using individual AAT18 values for feeds, the variations in the Nordic and Rostock systems differed less. This may indicate that the protein values of the feeds are not quite additive, and a more correct protein intake value can be calculated from the DOM and UDP values of the total diet. This would be a disadvantage to practical diet formulation.

The Rostock method is less sensitive to variations of feed protein degradation. The results of some experiments in the present study agree with that finding, e.g., when reducing the protein degradation of RSM had, on average, no effect on milk or protein yield. With the Nordic method the AAT value of hay was equal or even higher than that of grass silage, regardless of the higher digestibility of organic matter and the crude protein content of silage. The Rostock method gave higher protein values for silage than for hay. The values of protein feeds were also higher than those obtained with the Nordic method (Table 31).

The AAT system gave carbohydrate concentrates very high values compared to DCP values. The AAT value of barley was 40 to 50 per cent higher than that of good quality grass silage, and the value of hay was higher than that of silage cut earlier. JAAKKOLA and HUHTANEN (1992) have showed that the flow of non-ammonium nitrogen (NAN) remained almost equal when the proportion of concentrate (barley plus RSM) increased from 25 to $75 \%$ in the diet in terms of dry matter. In that study forage consisted either of direct cut silage or hay cut at the same maturity. Calculated on the basis of AAT, the AAT increase should have been $37 \%$ according to the concentrate. When the microbial AAT flow was calculated according to VoIGT and PIATKOWSKI (1991), the increase was almost the same as measured, i.e. 3 to 4 per cent with an increased proportion of the concentrate.

The results of the present study (experiment 4), where silage and hay cut at same maturity were compared, no difference between the two kinds of roughage in terms of milk yield was observed, and the calculated AAT consumption per $\mathrm{kg} \mathrm{ECM}$ was 3 grams higher on a diet of hay than on silage. A shortage of amino acids was evident, as replacing some of the concentrate with RSM increased the milk production on both diets

The fermentation characteristics of silage affect microbial protein synthesis. Good fermentation properties increase microbial protein synthesis, compensating for the greater amounts of bypass protein of dried forage (JAAKKOLA et al. 1991).

In experiment 6 (HEIKKILÅ et al., unpublished) silage cut at two different growth stages were compared. Calculated AAT values were equal for both lots of silage (EPD values were determined), yet milk production was $7.7 \%$ higher, and ME intake was $5.5 \%$ higher with the earlier lot of silage added to the diet than with the later one. Milk yield correlated much higher with CP or DCP concentrations than AAT concentrations in the diet.

There are considerable advantages in using the new protein systems compared to DCP in that the former can be developed far easier. Although these present studies show that on the diets commonly used in Finland, i.e. high quality grass silage and hay with grain-based concentrate, there are some problems associated with the AAT-system, but they can be overcome applying new knowledge. 
However, more research is needed to develop a more precise method of estimating the microbial protein synthesis in the rumen, which appears to be the most important protein source for dairy cows.

\section{Conclusions}

\subsection{Glucosinolate content}

In the course of the study the types of RSM were changed from single zero to double zero rapeseed varieties, whereby their glucosinolate contents were reduced from 40-50 to $15 \mu$ moles per gram of defatted meal. Heat-moisture treatment further reduced the glucosinolate content by half. The glucosinolate content of the latest Finnish turnip rape varieties is less than $10 \mu$ moles per gram of defatted meal.

\subsection{Effect of rapeseed meal on milk yield}

The inclusion of RSM in the concentrate to supplement the staple diet of grass silage of dairy cows (silage ad libitum) increased the average milk yield by $0.7 \mathrm{~kg}$ ECM per kg RSM dry matter. The average protein yield increased by 27 grams per kg RSM dry matter. These increases were statistically significant. Milk yield increased when the ratio of RSM in the concentrate was raised to between $12 \%$ and $16 \%$. Increasing the ratio of RSM further to $24 \%$ had a minor effect on milk yield. Although the additional RSM seemed to reduce the fat content significantly in one trial, a similar effect was not observed in the other trials. The effect on protein content of the milk was not significant. The effect RSM had on milk yield and quality was attributed to the increase in energy supply and the specific protein effects. RSM and SBM were of equal value when $12 \%$ or $24 \%$ of RSM in the concentrate were substituted with SBM with comparable protein contents.

\subsection{Protein protection}

Protecting the RSM protein by heat-moisture treatment reduced the effective rumen degradation
(EPD) by 6 to $20 \%$-units. In experiment 2, where EPD of RSM was reduced $20 \%$-units by the treatment, milk yield was improved significantly by heat-moisture treatment ( 21.9 vs. $23.9 \mathrm{~kg}$ milk/d). In two other experiments, where EPD of RSM was reduced 6 or $17 \%$-units, there was no effect on milk yield. In experiment 1 EPD of heated RSM was $39 \%$-units lower than that of untreated with no positive effect on milk yield. In that experiment heat treatment seemed to be too severe, judging by the reduced quantity of available lysine. One explanation for the different effect of treatment of RSM could be the level of glucosinolates. In experiment 2 the original level of glucosinolates in RSM was high, and was reduced by treatment. In the experiments 3 and 5 the glucosinolate content in RSM was lower, and presumably further reduction by the heat treatment did not give any advantage.

\subsection{Goitrin content of milk}

Changing from single zero to double zero varieties of RSM reduced the goitrin content of milk. Heatmoisture treating the RSM resulted in a further notable reduction in its goitrin content. For cows fed on heat-moisture treated RSM made of the "Kulta" variety, with a glucosinolate content of 2.5 $\mu$ moles per gram defatted meal, the goitrin content was only 3.5 to $6.4 \mu$ grams per litre. Such a low goitrin content of milk should not cause any risk of thyroid problems in people.

\subsection{DCP and AAT}

The applicable parameters for the utilization DCP and AAT were calculated from the average data of the feeding trials involving 34 groups of cows. The observations related to trials where a staple diet of silage was supplemented with concentrate of varying protein contents. In relating protein yield to the energy and protein supply, DCP was better than uncorrected AAT, whereas the protein utilization varied less with the AAT system than with DCP. The variation in protein utilization was further reduced when AAT was corrected in such a way 
that the rumen-degradability of protein increased, or the microbial synthesis became more efficient, or both. It would indicate that as far as cows with high milk yield are concerned, the AAT system exaggerates the role of rumen undegradable feed protein in the supply of absorbable protein. As a result, hay was given a better protein value than silage, and the calculated utilization of AAT was poorer with a diet of hay than with one of silage. As a consequence, the current calculation method leads to AAT variable requirements of AAT according to dietary variations. Using the method of VoIGT and PIATKOWSKI (1991) in estimating MPS, which gave the lowest coefficient of variation, the AAT values of silage, oat and rapeseed and soybean meals were increased, whereas AAT value of barley was reduced compared to AAT values of the system. These changes are supported by the present results.

The present feeding trial data is limited to predominantly silage-based feeding. The results of making corrections to AAT systems indicate trends only, and more basic study is needed especially conserning the efficiency of microbial protein synthesis with high producing dairy cows.

The AAT-PBV system, like the other new systems, has many advantages compared to DCP, which is at the end of its development. With the new protein systems there is more opportunity to fullfill the requirements of diminish nitrogen output into the environment, and it is possible to derive new knowledge concerning the protein metabolism in the ruminant.

\section{References}

ACKMAN, R.G. 1990. Canola fatty acids - an ideal mixture for health, nutrition, and food use. In: Shadidi, F. (ed.). Canola and rapeseed: production, chemistry, nutrition and processing technology. Van Nostrand Reinhold, New York. p. 81-98.

Ahlin, K.-Å., Emanuelson, M., EdQvist, L.-E., LaRsson, K. \& WiKtorsson, H. 1985. Rapeseed products as feed for dairy cows. Preliminary results from longterm study. In: Sørensen, H. (ed.). Advances in the production and utilization of cruciferous crops. In series: World Crops: Production, utilization, description, Vol. 11: 222-229.

AhraR, M. \& Schingoethe, D.J. 1979. Heat-treated soybean meal as a protein supplement for lactating cows. J. Dairy Sci. 62: 932-940.

Alderman, G. 1987. Comparison of rations calculated in the different systems. In: Jarrige, R. \& Alderman, G. (eds.). Feed evaluation and protein requirement systems for ruminants. Proc. CEC seminar, Brussels. CEC L2985 Luxembourg. p. 283-297.

ANDERSEN, P.E. 1985. Double low rapeseed meal in diets to dairy cows. In: Sørensen, H. (ed.), Advances in the production and utilization of cruciferous crops. In series: World Crops: Production, utilization, description, Vol. 11: 218-221.

ANJou, K., LÖNNERDAl, B., UPPSTRŌM, B. \& Åman, P. 1977. Composition of seeds from some Brassica cultivars. Swedish J. Agric. Res. 7: 169-178.

Anke, M., Schwarz, S., Hennig, A., Groppel, B., Grón, M., ZenKer, G. \& Glös, S. 1980. Der Einfluss zusätzlicher Zink- und Jodgaben auf rapsexraktionsbedingte Schäden beim Schwein. Mh. Veterinărmed. 35: 90-94.

APPELQViST, L.-Å. 1972. Chemical constituents of rapeseed. In: Appelqvist, L.-Å. \& Ohlson, R. (eds.). Rapeseed. Cultivation, composition, processing and utilization. Elsevier Publ. Co. Amsterdam 1972. p. 123-173.

APPELQVIST, L.A. \& JosefSSON, E. 1967. Method for quantitative determination of isothiocyanates and oxazolidinethiones in digests of seed meals of rape and turnip rape. $\mathrm{J}$. Sci. Food Agric. 18: 510-519.

ARC 1980. The nutrient requirements of ruminant livestock. Technical review by an Agricultural Research Council working party. Commonwealth Agricultural Bureaux, Farnham Royal, UK. 351 p.

ARC 1984. The nutrient requirements of ruminant livestock. Supplement No 1. Technical review by an Agricultural Research Council working party, Commonwealth Agricultural Bureaux, Farnham Royal, UK. 45 p.

Arstil.A, A., Krusius, F.-E. \& Peltol., P. 1969. Studies on the transfer of thio-oxazolidone-type goitrogens into cow's milk in goitre endemic districts of Finland and in experimental conditions. Acta Endocr. 60: 712-718.

Ashes, J.R., Mangan, J.L. \& SidHU, G.S. 1984. Nutritional availability of amino acids from protein cross-linked to protect against degradation in the rumen. Br. J. Nutr. 52: 239-247.

AsPLuND, M. \& McELROY, L.W. 1961. Effects of high levels of rapeseed oil meal in dairy cow rations on milk pro- 
duction. J. Dairy Sci. 44: 2338 (abstr.).

Bachmann, M., Theus, R., LOThy, J. \& Schlatter, C. 1985. Vorkommen von goitrogenen Stoffen in Milch. 1. Mitteilung: Übergang von Goitrin in die Milch von Kühen bei Verfütterung von Rapsextraktionsschrot. Zeitschr. Lebensm. Unters. Forsch. 181: 375-378.

BARKER, S.B. \& SUMMERSON, W.H. 1941. The colorimetric determination of lactic acid in biological materials. J. Biol. Chem. 138: 537-554.

BELL, J.M. 1984. Nutrients and toxicants in rapeseed meal: a review. J. Anim. Sci. 58: 996-1010.

— \& Jeffers, H.F. 1976. Variability in the chemical composition of rapeseed meal. Can. J. Anim. Sci. 56: 269-273.

— \& SHIRES, A. 1982. Composition and digestibility by pigs of hull fractions from rapeseed cultivars with yellow or brown seed coats. Can. J. Anim. Sci. 62: 557-565.

Belzile, R.J., Bellk, J.M. \& Wetter, L.R. 1963. Growth depressing factors in rapeseed oil meal. V. The effects of myrosinase activity on the toxicity of the meal. Can. J. Anim. Sci. 43: 169-173.

Ben-Ghedalia, D., McMeniman, N.P. \& Armstrong, D.G. 1978. The effect of partially replacing urea nitrogen with protein $\mathrm{N}$ on $\mathrm{N}$ capture in the rumen of sheep fed a purified diet. Br. J. Nutr. 39: 37-44.

Bengtsson, L., Hofsten, von, A. \& Löf, B. 1972. Botany of rapeseed. In: Appelqvist, L.-Ả. \& Ohlson, R. (eds.). Rapeseed. Cultivation, composition, processing and utilization. Elsevier Publ. Co. Amsterdam. p. 36-48.

Benns, G., L'AbBé, M.R. \& Lawrence, J.F. 1979. Highpressure liquid chromatography detection of the antithyroid compound 5-vinyloxazolidine-2-thione in milk. J. Agric. Food Chem. 27: 426-428.

BergNeR, H. \& SCHMIDT, W. 1972. Untersuchungen zur Wirkung von Rapsextraktionsschrot auf das Kükenwachstum. 3. Mitteilung. Die Wirkung von gestaffelten Rapsextraktionsschrotgaben auf den 131J- Einbau in die Kükenschilddrüse. Arch. Tierernăhrg. 22: 4147.

BERTILSSON, J. 1991. Different protein levels to dairy cows effect of reduced protein degradability and lower nitrogen supply on animal performance. 6th Int. Symp. Protein Metabolism and Nutrition. Herning, Denmark. p. 309 - 311 .

Bertram, H.J., Brauer, D., Lembke, K.G., Hatje, G., HenKel, H., Kley, G., LANGe, D., Lennerts, L. \& RÖBbeLEN, G. 1986. Raps auf neuen Wegen: 00-Sorten in Züchtung, Anbau und Verwendung. Verlag Th. Mann. Gelsenkirchen-Buer, 98 p.

Bhatty, R.S., McKenzie, S.L. \& Finlayson, A.J. 1968. The proteins of rapeseed (Brassica napus L.) soluble in salt solutions. Can. J. Biochem. 46: 1191-1197.

BICKEL, H. \& LANDIS, J. 1987. Present situation of protein evaluation for ruminants in Switzerland. In: Jarrige, R. \& Alderman, G. (eds.). Feed evaluation and protein requirement systems for ruminants. Proc. CEC seminar, Brussels. CEC L-2985 Luxembourg. p. 41-45.
BJôRKQVist, B. \& HASE, A. 1988. Separation and determination of intact glucosinolates in rapeseed by high-performance liquid chromatography. J. Chromatogr. 435: 501-507.

BRoDERICK, G.A. 1987. Determination of protein degradation rates using a rumen in vitro system containing inhibitors of microbial nitrogen metabolism. Br. J. Nutr. 58: 463-475.

— \& Clayton, M.K. 1992. Rumen protein degradation rates estimated by non-linear regression analysis of Michaelis- Menten in vitro data. Br. J. Nutr. 67: 27-42.

BÖnger, H., FisSMer, E. \& REISING, F. 1940. Fütterungsversuche mit Rapsrückständen an Milchkühen. Zeitschr. Tierernähr. Futtermittelkde. 4: 183-200.

Burgess, P.L. \& Nicholson, J.W. 1984. Protein levels in grass silage-based total mixed rations for dairy cows in midlactation. Can. J. Anim. Sci. 64: 435-442.

Cameron, M.R., Klusmeyer, T.H., Lynch, G.L., Clark, J.H. \& Nel.SON, D.R. 1991. Effects of urea and starch on rumen fermentation, nutrient passage to the duodenum, and performance of cows. J. Dairy Sci. 74: 1321-1336.

CAmpBell, L.D. \& SlominsKi, B.A. 1991. Nutritive quality of low-glucosinolate Canola meal for laying hens. Proc. 8 ht Int. Rapeseed Congr., Saskatoon, Canada. Vol. 2: 442-447.

CARR, R. 1989. Processing of oilseed. In: Röbbelen, G.R. et al. (eds.). Oil crops of the world: Their breeding and utilization. McGraw-Hill Publ. Co, New York. p. 226-259.

Castle, M.E. \& Watson, J.N. 1976. Silage and milk production. A comparison between barley and groundnut cake as supplements to silage of high digestibility. J. Br. Grassld. Soc. 31: 191-195.

— \& WATSON, J.N. 1984. Silage and milk production: a comparison between concentrates containing different amounts of protected protein as supplements for silage of high digestibility. Grass and Forage Sci. 39: 93-99.

Chalupa, W.V. 1992. A model to estimate rumen escape protein and amino acid composition. Proc. Distiller Feed Confer., Cinc. Ohio, USA. Vol. 47: 87-97.

Chamberlain, D.G. 1987. The silage fermentation in relation to the utilization of nutrients in the rumen. Process Biochemistry, April 1987: 60-63.

-, Martin, P.A. \& RoBertson, S. 1989. Optimizing compound feed use in dairy cows with high intakes of silage. In: Haresign, W \& Cole, D.J.A. (eds.). Recent Advances in Animal Nutrition. Butterworths. p. 175-193.

Chen, G., Sniffen, C.J. \& Russell, J.B. 1987. Concentration and estimated flow of peptides from the rumen of dairy cattle: effects of protein quantity, protein solubility, and feeding frequency. J. Dairy Sci. 70: 983-992.

Clandinin, D.R., Robblee, A.R., Slinger, S.J. \& Bell, J.M. 1981. Composition of canola meal. In: Canola meal for livestock and poultry. Publ. 59: 8-11. Canola Council of Canada, Winnipeg.

Classen, H.L., Bell, J.M. \& Clark, W.D. 1991. Nutritio- 
nal value of very low glucosinolate Canola meal for broiler chickens. Proc. 8th Int. Rapeseed Congr., Saskatoon, Canada. Vol 2: 390-395.

Cody, R.F., MurPhy, J.J. \& Morgan, D.J. 1990. Effect of supplementary crude protein level and degradability in grass silage-based diets on performance of dairy cows, and digestibility and abomasal nitrogen flow in sheep. Anim. Prod. 51: 235-244.

Colucci, P.E., Chase, L.E. \& VAn Soest, P.J. 1982. Feed intake, apparent diet digestibility, and rate of particulate passage in dairy cattle. J. Dairy Sci. 65: 1445-1456.

—, Macleod, G.K., Grovum, W.L., McMillan, I. \& Barney, D.J. 1990. Digesta kinetics in sheep and cattle fed diets with different forage to concentrate ratios at high and low intakes. J. Dairy Sci. 73: 2143-2156.

Craig, W.M., Brown, D.R., Broderich, G.A. \& Ricker, D.B. 1987. Post-prandial compositional changes of fluid- and particle-associated ruminal microorganisms. J. Anim. Sci. 65: 1042-1048.

Davis, A.W. \& Hall, W.B. 1969. Cyclic change-over designs. Biometrika 56: 283-293.

DemeYer, D. \& VAN Nevel, C. 1979. Protein fermentation and growth by rumen microbes. Ann. Rech. Vet. 10: 277-279.

DOWNEY, R.K. \& RöBbelen, G. 1989. Brassica species. In: Röbbelen, G.R. et al. (eds.). Oil crops of the world: Their breeding and utilization. McGraw-Hill Publ.Co. New York. p. 339-362.

EAPEN, K.E., TAPE, N.W. \& SiMS, R.P. 1968. New process for the production of better quality rapeseed oil and meal. I. Effect of heat treatments on enzyme destruction and color of rapeseed oil. J. Am. Oil Chem. Soc. 45: 194196.

Elimam, M.E. \& ØRSKov, E.R. 1984. Factors affecting the outflow of protein supplements from the rumen. 1. Feeding level. Anim. Prod. 38: 45-51.

EMANUELSON, M. 1989. Rapeseed products of double low cultivars to dairy cows: Effects of long-term feeding and studies on rumen metabolism. Swedish Univ. Agric. Sci. Dept. Anim. Nutr. Managem. Report 189, 182 p.

-, Ahlin, K.-Ä. \& Wiktorson, H. 1991. Rapeseed products of 00-cultivars to dairy cows. Effects of long-term feeding on animal performances. Proc. 8th Int. Rapeseed Cong., Saskatoon, Canada. Vol. 2: 430-435.

EMERY, R.S. 1978. Feeding for increased milk protein. J. Dairy Sci. 61: 825-828.

EtienNe, M., Dourmad, J.Y., OBidzinski, W., Evrard, J. \& VACHOT, C. 1991. Effects of low glucosinolate rapeseed meal in sow pregnancy diet. Proc. 8th Int. Rapeseed Congr., Saskatoon, Canada. Vol. 2: 376-381.

EtTALA, E. 1976. Factors affecting the composition of milk. I. Effect of energy and protein levels in grass silage- and pasture-based diets. Ann. Agric. Fenn. 15: 182-195.

— \&LAMPILA, M. 1974. Konserverat gräs som energi- och proteinkälla för mjölkkor. NJF:s grovfodersymposium, Randers. Husdjur 45: F: 1-11.
-, Lampila, M. \& Rissanen, H. 1978. Effect of concentrate feeding level in grass silage-based diets on milk production of dairy cows. Ann. Agric. Fenn. 17: 175185.

—, TAKALA, M. \& LAMPILA, M. 1974. Typpilannoitustasot lypsylehmien säilörehuruokinnassa. Kehittyvă Maatalous 18: 51-59.

EtTlinger, M.G. \& LundeEn, A.J. 1954. The structure of sinigrin and sinalbin; an enzymatic rearrangement. J. Amer. Chem. Soc. 78: 4172.

FALDET, M.A. \& SATTER, L.D. 1991. Feeding heat-treated full fat soybeans to cows in early lactation. J. Dairy Sci. 74: 3047-3054.

FAO 1991. FAO yearbook Production 1990, vol 44. FAO Statistics Series no. 99, Rome, 1991. 379 p.

FENWICK, G.R. \& HEANEY, R.K. 1983. Glucosinolates and their breakdown products in cruciferous crops, foods and feedingstuffs. Food Chem. 11: 249-271.

-, Pearson, A.W., Greenwood, N.M. \& Butler, E.G. 1981. Rapeseed meal tannins and egg taint. Anim. Feed Sci. Technol. 6: 421-431.

Fenwick, R.G. \& Hoggan, H.A. 1976. The tannin content of rapeseed meals. Br. Poult. Sci. 17: 59-62.

Ferlay, A., Legay, F., Bauchart, D., Poncet, C. \& DOREAU, M. 1992. Effect of a supply of raw or extruded rapeseeds on digestion in dairy cows. J. Anim. Sci. 70: 915-923.

FInLAYSON, J. 1974. The amino acid composition of rapeseed hulls. Can. J. Anim. Sci. 54: 495-496.

FIRKINS, J.L., BERGER, L.L., MERCHEN, N.R., FAHEY, G.C. \& MulVANEY, R.L. 1987a. Ruminal nitrogen metabolism in steers as affected by feed intake and dietary urea concentration. J. Dairy Sci. 70: 2302-2311.

-, Lewis, S.M., MONTGOMery, L., Berger, L.L., MERCHEN, N.R. \& FAHEY, G.C. Jr. 1987b. Effects of feed intake and dietary urea concentration on ruminal dilution rate and efficiency of bacterial growth in steers. J. Dairy Sci. 70: 2312- 2321.

GaNEV, G., ØrSKov, E.R. \& SMART, R. 1979. The effect of roughage or concentrate feeding and rumen retention time on total degradation of protein in the rumen. J. Agric. Sci. 93: 651-656.

GARNSWORTHY, P.C. 1989. The interaction between dietary fibre level and protein degradability in dairy cows. Anim. Prod. 48: 271-281.

GlenN, B.P., Varga, G.A., Huntington, G.B. \& Waldo, D.R. 1989. Duodenal nutrient flow and digestibility in Holstein steers fed formaldehyde- and formic acid-treated alfalfa or orchardgrass silage at two intakes. J. Anim. Sci. 67: 513-528.

GmelIN, R. 1969. Glucosinolate (Senfölglucocide). Präp. Pharm. 5: 33-41.

GoERING, H.K. \& VAN SOEST, P.J. 1970. Forage fibre analysis (Apparatus, reagents, procedures and some applications). USDA Agricultural Handbook, No. 379, Washington, DC. 20 p. 
Goh, Y.K., Mueller, M.M., Clandinin, D.R. Robblee, A.R. 1979. The effects of choline and sinapine bisulfate in a laying ration on the incidence of fishy odor in eggs from brown-shelled egg layers. Can. J. Anim. Sci. 59: 545-549.

—, Robblee, A.R. \& Clandinin, D.R. 1985. Influence of glucosinolates and free oxazolidinethione in a laying diet containing a constant amount of sinapine on the thyroid size and hepatic trimethylamine oxidase activity of brown-egg layers. Can. J. Anim. Sci. 65: 921-927.

GORDON, F.J. 1979. The effect of protein content of the supplement for dairy cows with access ad libitum to high digestibility, wilted grass silage. Anim. Prod. 28: 183189.

- 1980. The effect of silage type on the performance of lactating cows and the response to high levels of protein in the supplement. Anim. Prod. 30: 29-37.

- 1984. The effect of level of concentrate supplementation given with grass silage during the winter on the total lactation performance of autumn-calving dairy cows. J. Agric. Sci. 102: 163-179.

- 1987. The influence of the system of silage harvesting and feeding and the use of protected protein on milk production. Grass and Forage Sci. 42: 9-19.

— \& MCMurRaY, C.H. 1979. The optimum level of protein in the supplement for dairy cows with access to grass silage. Anim. Prod. 29: 283-291.

— \&UNSWORTH, E.F. 1986. The effects of silage harvesting system and supplementation of silage-based diets by protein and methionine hydroxy analogue on the performance of lactating cows. Grass and Forage Sci.41: 1-8.

Hadjipanayiotou, M., Koumas, A., Georghiades, E. \& HADJIDEMETRIOU, D. 1988. Studies on degradation and outflow rate of protein supplements in the rumen of dry and lactating Chios ewes and Damascus goats. Anim. Prod. 46: 243-248.

Hagemeister, H., Lôpping, W. \& KaufmanN, W. 1980. Microbial protein synthesis and digestion in the highyielding dairy cow. In: Haresign, W. (ed.). Recent advances in animal nutrition -1980 , Nutr. Conf. Feed Man. 14th. p. 67-84.

HARVEY, W.R. 1966. Least-square analysis of data with unequal subclass numbers. ARS 20-8, Agric. Res. Service, U.S. Dept. Agric. 157 p.

Hase, A., Johansson, M.-L. \& Viljava, T.-R. 1988. Sources of error in the analysis of glucosinolates by gas liquid chromatography. J. Am. Oil Chem. Soc. 65:647651 .

HeANEY, R.K. \& FENwiCK, G.R. 1980. The analysis of glucosinolates in Brassica species using gas chromatography. Direct determination of the thiocyanate ion precursors, glucobrassicin and neoglucobrassicin. J. Sci. Food Agric. 31: 593-599.

- \&FENWICK, G.R. 1985. Brassica vegetables - a major source of glucosinolates in the human diet. In: Sørensen, H. (ed.). Advances in the production and utilization of cruciferous crops. In series: World Crops: Production, utilization, description, Vol. 11: 40-49.

HEIKKILÄ, T., VÄĀTÃINEN, H., LAMPILA, M. \& TOIVONEN, V. 1989. Săilöntäaineet săilörehun valmistuksessa. Säilöntäaine- ja väkirehukoe. MTTK, KEL/ERA. Toimintakertomus ja tutkimustuloksia 1989, Jokioinen, Finland. p. 57.

Helboe, P., Olsen. O. \& Sørensen, H. 1980. Separation of glucosinolates by high performance liquid chromatography. J. Chromatogr. 197: 199-205.

HenKel, H. \& Mosenthin, R. 1989. Rapssaat und Rapsprodukte in der Tierernăhrung. Übersicht. Tierernährg. 17: 139-190.

HILL, R. 1979. A review of the toxic effects of rapeseed meals with observations on meal from improved varieties. Br. Vet. J. 135: 3-16.

- 1991. Rapeseed meal in the diets of ruminants. Nutr. Abstr. Rev. (Series B): 139-155.

Hobson-Frohock, A., LAND, D.G., GrifFiths, H.S. \& CuRTIS, R.F. 1973. Egg taints: association with trimethylamine. Nature 243: 304-305.

Holter, J.B., Byrne, J.A. \& SchwaB, C.G. 1982. Crude protein for high milk production. J. Dairy Sci. 65: 11751188.

Huhtanen, P. 1991. The response to replacement of barley with wheat bran and treatment of rapeseed meal in the diets of dairy cows given grass silage ad libitum. Acta Agric. Scand. 41: 415- 426.

— \& KHALILI, H. 1991. Sucrose supplements in cattle given grass silage-based diet. 3. Rumen pool size and digestion kinetics. Animal Feed Sci. Technol. 33: 275-287.

— \& Khalili, H. 1992. The effect of sucrose supplements on particle-associated carboxymethylcellulase (EC 3.2.1.4) and xylanase (EC 3.2.1.8) activities in cattle given grass-silage-based diet. Br. J. Nutr. 67: 245-255.

—, KhalILI, H. \& NÄSI, M. 1991. A comparison of untreated and formaldehyde-treated barley distiller's solubles and rapeseed meal as protein supplements in dairy cows given grass silage ad libitum. J. Agric. Sci. Finl. 63: 455463.

HuIDA, L. 1973. Quantitative determination of volatile fatty acids from rumen sample and silage by gas-liquid chromatography. J. Scient. Agric. Soc. Finl. 45: 483-488.

HVElPLuND, T. 1985. Digestibility of rumen microbial protein and undegraded dietary protein estimated in the small intestine of sheep and by in sacco procedure. Acta Agric. Scand. Suppl. 25: 132-144.

- 1986. The influence of diet on nitrogen and amino acid content of mixed rumen bacteria. Acta Agric. Scand. 36: 325- 331 .

- 1990. The AAT-PBV protein evalution system. Notes from a Nordic meeting concerning the AAT-PBV protein evaluation system, held at Tune Landboskole Denmark, 3rd-5th December 1990.

— \& MAdsen, J. 1985. Amino acid passage to the small intestine in dairy cows compared with estimates of 
microbial protein and undegraded dietary protein from analysis on the feed. Acta Agric. Scand. Suppl. 25: 2136.

— \& MADSEN, J. 1990. A study of the quantitative nitrogen metabolism in the gastro- intestinal tract, and the resultant new protein evaluation system for ruminants. The AAT- PBV system. Diss. Inst. Anim. Sci. Royal Vet. Agric. Univ. Copenhagen. 62 p.

— \& Møller, E. 1987. Proteinvurdering af graes og klover ved forste slaet. XVIII. NJF congres, Ảrhus, 5 p.

— \& Møller, P.D. 1980. Fodringens indflydelse på vombakteriernes kemiske sammensaetning. Medd. nro 310, Statens Husdyrbrugsforsøg, Copenhagen.

— \& WeisbJerg, M.R., Hvelplund, T. \& Andersen, L.S. 1992. Estimation of the true digestibility of rumen undegraded dietary protein in the small intestine of ruminants by the mobile bag technique. Acta Agric. Scand. Sect. A, Anim. Sci. 42: 34-39.

Ingalls, J.R. \& Sharma, H.R. 1975. Feeding Bronowski, Span and commercial rapeseed meals with or without addition of molasses or flavor in rations of lactating cows. Can. J. Anim. Sci. 55: 721-729.

-, SEALE, M.E. \& MCKIRDY, J.A. 1968. Effect of rapeseed meal and urea on ad libitum consumption of grain rations by dairy cows. Can. J. Anim. Sci. 48: 437-442.

INRA 1978. Alimentation des ruminants. Institut National de la Recherche Agronomique of France. INRA Publications, Versailles. 597 p.

Iwarsson, K. \& Nilsson, P.O. 1973. Rape seed meal as a protein supplement for dairy cows. II. Investigations in rats on the goitrogenic properties of milk from cows fed rapeseed meal. Acta Vet. Scand. 14: 595-609.

JAAKKOLA, S. \& HUHTANEN, P. 1990. Nitrogen digestion and rumen fermentation in cattle given silage or dried grass with three levels of concentrate. Proc. 9th Silage Conf. Faculty of Agric. Univ. Newcastle upon Tyne, UK. p. 116-117.

— \& HuHTANEN, P. 1992a. The effect of grass maturity on nitrogen metabolism in the rumen of cattle receiving silage- based diet. Proc. 14th Gen. Meet. European Grassland Federation, Lahti, Finland. p. 588-590.

- Huhtanen, P. 1992b. The effects of the forage preservation method and the proportion of concentrate on nitrogen digestion and rumen fermentation in cattle. Grass For. Sci. 1992 (in press).

-, Huhtanen, P. \& Hissa, K. 1991. The effect of cell wall degrading enzymes or formic acid on fermentation quality and on digestion of grass silage by cattle. Grass For. Sci. 46: 75- 87 .

JARL, F. 1951. Utfodringsförsök med svenskt rapsmjöl till mjölkkor. Kungl. Lantbrukshögskolan och Statens Lantbruksförsök. Statens Husdjursförsök, meddelande nr 45: 1-42.

Kaim, M., Neumark, H., Folman, Y. \& Kaufmann, W. 1987. The effect of two concentrations of dietary protein and of formaldehyde-treated soya-bean meal on the per- formance of high- yielding dairy cows. Anim. Prod. 44: 333-345.

KaUfmanN, W. 1977. Calculation of the protein requirements for dairy cows according to measurements of $\mathrm{N}$ metabolism. In: Protein metabolism and nutrition. Eur. Assoc. Anim. Prod. Publ. 22: 126-129. Wageningen 1977.

— \& LỐPPING, W. 1979. Zum Einfluss von Protected protein und HMM-Ca auf die Leistung von Milchkühen. Zeitschr. Tierphysiol. Tierernährg. Futtermittelkde. 41: 202-217

Klusmeyer, T.H., McCarthy, R.D. Jr., Clark, J.H. \& NELSON, D.R. 1990. Effect of source and amount of protein on ruminal fermentation and passage of nutrients to the small intestine of lactating cows. J. Dairy Sci. 73: 3526-3537.

KozlowsKa, H., NACZK, M., SHAHIDI, F. \& ZADERNOWSKI, R. 1990. Phenolic acids and tannins in rapeseed and Canola. In: Shahidi, F. (ed.). Canola and rapeseed: production, chemistry, nutrition and processing technology. Van Nostrand Reinhold, New York. p. 193-210.

Kristensen, E.S., Møller, P.D. \& Hvelplund, T. 1982. Estimation of the effective protein degradability in the rumen of cows using the nylon bag technique combined with the outflow rate. Acta Agric. Scand. 32: 123-127.

Kristensen, V.F., Munksgaard, L. \& Andersen, P.E. 1985. Protein value of grass silage for dairy cows. Acta Agric. Scand. Suppl. 25: 145-154.

Krusius, F.-E. \& PeltolA, P. 1966. The goitrogenic effect of naturally occuring L-5-vinyl- and L-5- phenyl-2-thiooxazolidone in rats. Acta Endocr. 53: 342-352.

LAARVELD, B. \& Christensen, D.A. 1976. Rapeseed meal in complete feeds for dairy cows. J. Dairy Sci. 59: 1929 . 1935.

Laird, R. Leggate, A.T. \& Castle, M.E. 1979. The effect of supplementary protein on the performance of dairy cows offered grass silage ad libitum. Anim. Prod. 29: 151-156.

LINDBERG, J.E. 1982. Ruminal flow rate of soya-bean meal, rapeseed meal and cottonseed meal in cows fed at maintenance and at three times maintenance. J. Agric. Sci. 98: 689-691.

- 1985. Estimation of rumen degradability of feed proteins with the in sacco technique and various in vitro methods: a review. Acta Agric. Scand. Suppl. 25: 64-97.

- 1988. Influence of cutting time and $\mathrm{N}$ fertilization on the nutritive value of timothy. 2 . Estimates of rumen degradability of nitrogenous compounds. Swedish J. Agric. Res. 18: 85-89.

LINDELL, L. 1976. Rapeseed meal in rations for dairy cows. 2. Comparison of two levels of rapeseed meal. Swedish J. Agric. Res. 6: 65-71.

— \& KNUTSSON, P.-G. 1976. Rapeseed meal in rations for dairy cows. 1. Comparison of three levels of rapeseed meal. Swedish J. Agric. Res. 6: 55-63.

Maa- ja metsătalousministeriő 1975. Öljykasvitoimikunnan 
mietintö. Komiteamietintő 1975:63. Helsinki. 109 p.

MADSEN, J. 1985. The basis for the proposed Nordic protein evaluation system for ruminants. The AAT-PBV system. Acta Agric. Scand. Suppl. 25: 9-20.

MAFF 1975. Energy allowance and feeding systems for ruminants. Tech. Bull.33. 79 P. London.

MÄKELĀ, A. 1956. Studies on the question of bulk in the nutrition of farm animals with special reference to cattle. Acta Agralia Fennica 85: 1-130.

Marangos, A. \& Hill, R. 1974. The hydrolysis and absorption of thioglucosides of rapeseed meal. Proc. Nutr. Soc. 33: $90 \mathrm{~A}$ (abstr.).

MARCH, B.E. \& MACMILlan, C. 1978. Trimethylamine production in the caeca and small intestine as a cause of fishy taints in eggs. Poultry Sci. 58: 93-98.

MAYNE, C.S. \& GoRdON, F.J. 1984. The effect of type of concentrate and level of concentrate feeding on milk production. Anim. Prod. 39: 65-76.

- \& Gordon, F.J. 1985. The effect of concentrate-toforage ratio on the milk-yield response to supplementary protein. Anim. Prod. 41: 269-279.

McCarthy, R.D., Klusmeyer, T.H., Vicini, J.L., Clark, J.H. \& Nelson, D.R. 1989. Effects of source of protein and carbohydrate on ruminal fermentation and passage of nutrients to the small intestine of lactating cows. J. Dairy Sci. 72: 2002-2016.

McCullough, H. 1967. Determination of ammonia in whole blood by a direct colorimetric method. Clin. Chem. Acta. 17: 297-304.

MCDONALD, I. 1981. A revised model for the estimation of protein degradability in the rumen. J. Agric. Sci. 96: 251-252.

MCGregor, D.I. 1990. Application of near infrared to the analysis of oil, protein, chlorophyll, and glucosinolates in Canola/rapeseed. In: Shadidi, F. (ed.). Canola and rapeseed: production, chemistry, nutrition and processing technology. Van Nostrand Reinhold, New York. p. 221-231

-, Mullin, W.J. \& Fenwick, G.R. 1983. Review of analysis of glucosinolates: analytical methodology for determining glucosinolate composition and content. J. Assoc. Offic. Anal. Chem. 66: 825-849.

MehreZ, A.Z. \& ØRSKov, E.R. 1977. A study of the artificial fibre bag technique for determining the digestibility of feeds in the rumen. J. Agric. Sci. 88: 645-650.

Menzel, E. 1983. Untersuchungen über die schildrüsenvergrössernde (strumigene) Wirkung rapshaltiger Rationen in Abhängigkeit von der Rapssorte, dem Glucosinolatgehalt und Fütterungszusätzen. Diss. Christian- Albrechts-Univ. Kiel. 143 p.

MerRy, R.J. \& MCAllan, A.B. 1983. A comparison of the chemical composition of mixed bacteria harvested from the liquid and solid fractions of rumen digesta. $\mathrm{Br}$. J. Nutr. 50: 701-709.

MEYER, J.H. \& MACKIE, R.I. 1986. Microbiological evaluation of the intraruminal in sacculus digestion technique.
Appl. Environm. Microbiol. 51: 622-629.

Michalet-Doreau, B. \& OUld-BaH, M.Y. 1989. Estimation of the extent of bacterial contamination in bag residues and its influence on in sacco measurements of forage nitrogen degradation in rumen. XVI International Grassland Congress, Nice, France, 1989: 909-910.

Møller, P., Plöger, A. \& Sørensen, H. 1985. Quantitative analysis of total glucosinolate content in concentrated extracts from double low rapeseed by the Pd- glucosinolate complex method. In: Sørensen, H. (ed.). Advances in the production and utilization of cruciferous crops. In series: World Crops: Production, utilization, description, Vol. 11: 97-110.

Morgan, D.J. 1985. The effect of formalin-treated soya bean meal upon the performance of lactating cows. Anim. Prod. 41: 33-42.

Mueller, M.M., RYl, E.B., Fenton, T. \& Clandinin, D.R. 1978. Cultivar and growing location differences on the sinapine content of rapeseed. Can. J. Anim. Sci. 58: 579583.

Murphy, J.J., Gleeson, P.A. \& Morgan, D.J. 1985. Effect of protein source in the concentrate on the performance of cows offered grass silage ad-libitum. Ir. J. Agric. Res. 24: 151-159.

Murphy, D.J., Cummins, I., Edwards, E.W., Hills, M.J. \& LI, M. 1991. Oleosins - a new class of abundant seed protein in rapeseed. Proc. 8th Int. Rapeseed Congr., Saskatoon, Canada. Vol 3: 922-927.

NACZK, M. ShahIDI, F. 1990. Carbohydrates of canola and rapeseed. In: Shadidi, F. (ed.). Canola and rapeseed: production, chemistry, nutrition and processing technology. Van Nostrand Reinhold, New York. p. 211-220.

NÄSI, M. 1991. Digestibility and protein utilization responses of soyabean and rape seed meal to physical and enzymatic treatments in diets for growing pigs. J. Agric. Sci. Finl. 63: 465-474.

— \& HuIDA, L. 1982. Digestibility of amino acids in pig diets containing Eurolysine bacterial protein or Pekilo protein, with special reference to a gas chromatographic method used in amino acid determination. J. Agric. Soc.Finl. 54: 279-285.

— \& SilJANDER-RASI, H. 1991. Effects of thermal processing on digestibility and protein utilization of rapeseed meal of medium and low glucosinolate type in diets for growing pigs. J. Agric. Sci. Finl. 63: 475-482.

—, Alaviuhrola, T. \& Suomi, K. 1985. Rapeseed meal of low- and high-glucosinolate type fed to growing-finishing pigs. J. Agric. Sci. Finl. 57: 263-269.

National board of agriculture 1991a. Monthly review of agricultural statistics 10/1991. Helsinki. $31 \mathrm{p}$.

National board of agriculture. 1991b. Yearbook of farm statistics 1990. Official statistics of Finland, Agriculture and forestry 1991:2. Helsinki. 254 p.

NCR 1985. Ruminant nitrogen usage. National Research Council (U.S.) Subcommittee on Nitrogen Usage in Ruminants. US National Academy of Sciences, Was- 
hington DC. $138 \mathrm{p}$.

NKJ 1985. Protein evaluation for ruminants. Proc. NKJ-NJF Seminar no. 72, Copenhagen. Acta Agric. Scand. Suppl. 25. $222 \mathrm{p}$.

NORDFELDT, S. 1958. Smältbarhetsförsök och utfodringsförsök med rapsmjöl och senapsmjöl med låg resp. hög fetthalt till mjölkkor. Kungl. Lantbrukshögskolan och Statens Lantbruksförsök. Statens Husdjursförsök, meddelande $\mathrm{nr}$ 66: 1-38.

NorTON, G. 1989. Nature and biosynthesis of storage proteins. In: Röbbelen, G.R. et al. (eds.). Oil crops of the world: Their breeding and utilization. McGraw-Hill Publ.Co. New York. p. 165-191.

NousiaINEN, J. 1992. Säilörehun ja heinän AAT- ja PBVarvojen laskeminen NIR- ja titrausanalytiikan avulla. Suomen Maatal. Tiet. Seuran Tiedote 16: 143-150

Nwokolo, E.N. \& BragG, D.B. 1977. Influence of phytic acid and crude fibre on the availability of minerals from four protein supplements in growing chicks. Can. J. Anim. Sci. 57: 475-477.

OLdHAM, J.D. 1987. Towards a European standard method for assessing protein degradability. Circular in connection with EAAP-EEC work shop. Brussels. 4 p.

- 1987a. Efficiencies of amino acid utilisation. In: Jarrige, R. \& Alderman, G. (eds.). Feed evaluation and protein requirement systems for ruminants. Proc. CEC seminar, Brussels, CEC L-2985 Luxembourg. p. 171- 186.

- 1987b. Testing and implementing the modern systems: UK. In: Jarrige, R. \& Alderman, G. (eds.). Feed evaluation and protein requirement $\mathrm{s}$ ystems for ruminants. Proc. CEC seminar, Brussels, CEC L-2985 Luxembourg. p. 269-281.

OluboboKun, J.A., Graig, W.M. \& NipPer, W.A. 1988. Characteristics of protozoal and bacterial fractions from microorganisms associated with ruminal fluid or particles. J. Anim. Sci. 66: 2701-2710.

ØRSKOV, E.R. \& MCDONALD, I. 1979. The estimation of protein degradability in the rumen from incubation measurements weighted according to rate of passage. J. Agric. Sci. 92: 499-503.

-, Hughes-Jones, M. \& McDonald, I. 1980. Degradability of protein supplements and utilization of undegraded protein by high-producing dairy cows. In: Haresign, W. (ed.). Recent advances in animal nutrition -1980 , Nutr. Conf. Feed Man. 14th. p. 85-98.

-, ReID, G.W. \& McDonald, I. 1981. The effects of protein degradability and food intake on milk yield and composition in cows in early lactation. Br. J. Nutr. 45: 547-555.

Pahkala, K. \& Sovero, M. 1988. The cultivation and breeding of oilseed crops in Finland. Ann. Agric. Fenn. 27: 199-207.

Papas, A.M., Ames, S.R., CoOK, R.M., Sniffen, C.J., Polan C.E. \& CHASE, L. 1984. Production responses of dairy cows fed diets supplemented with ammonium salts of iso C-4 and C-5 acids. J. Dairy Sci. 67: 276-293.
Papas, A., Ingalls, J.R. \& Cansfield, P. 1978. Effects of Tower and 1821 rapeseed meals and Tower gum on milk yield, milk composition and blood parameters of lactating dairy cows. Can. J. Anim. Sci. 58: 671-679.

Pearson, A.W., Butler, E.J., Curtis, R.F., Fenwick, G.R., Hobson-Frohock, A. \& LAND, D.G. 1979. Effect of rapeseed meal on trimethylamine metabolism in the domestic fowl in relation to egg taint. J. Sci. Food Agric. 30: 799-804.

Peirce-Sandner, S.B., Papas, A.M., Rogers, J.A., SweeNEY, T.F., Cummins, K.A., ConRad, H.R. \& Muller, L.D. 1985. Supplementation of dairy cow diets with ammonium salts of volatile fatty acids. J. Dairy Sci. 68 : 2895-2907.

Peltola, P. 1960. Goitrogenic effect of cow's milk from the goitre district of Finland. Acta Endocr. 34: 121-128.

PEOPLES, A.C. \& Gordon, F.J. 1989. The influence of wilting and season of silage harvest and the fat and protein concentration of the supplement on milk production and food utlization by lactating cattle. Anim. Prod. 48: 305317.

PiatKowski, B., Gôrtler, H. \& Voigt, J. 1990. Grundzüge der Wiederkäuer-Ernährung. Gustav Fischer Verlag Jena 1990, 232 p.

POUÅRVI, I. 1944. Inhemska linfrö-, vallmo- och rapskakors fodervärde. Praktisk Försöksverksamhet 1,7: 4-6.

Porter, M.G., PATterson, D.C., Steen, R.W. Gordon, F.J. 1984. Determination of dry matter and gross energy of grass silage. In: Gordon, F.J. \& Unsworth, E.F. (eds.). Seventh silage conference 1984,The Queen's University of Belfast. p. 89- 90.

RAE, R.C. \& SMITHARD, R.R. 1985. Estimation of true nitrogen digestibility in cattle by a modified nylon bag technique. Proc. Nutr. Soc. 44: 116A.

—, INGALlS J.R. \& McKIRDY, J.A. 1983. Response of dairy cows to formaldehyde-treated canola meal during early lactation. Can. J. Anim. Sci. 63: 905-915.

RAJAMÄKI, S. \& RAURAMAA, A. 1984. The automated determination of urea in milk. Finn. Chem. Lett. 2:47-48.

RauramaA, A. 1983. Content of L-5-vinyl-2-thio-oxazolidone in milk. Finnish Chemistry (Kemia-kemi) 10, no. 11: 964 (abstr.).

REES, P. \& Rowlinson, P. 1983. The effects of soya protein degradability upon the production and food intake of dairy cows offered grass silage ad libitum. Anim. Prod. 36: 502 (abstr.).

REYNOLDS, J.R. \& YounG, C.G. 1964. Effect of seed preparation on efficiency and oil quality in filtration extraction of rapeseed. J. Am. Oil Chem. Soc. 41: 63-65.

RöbBelen, G. \& ThiEs, W. 1980. Biosynthesis of seed oil and breeding for improved oil quality of rapeseed. In: Tsunoda, S. et al. (eds.). Brassica crops and wild allies. Biology and breeding. Japan Sci. Soc. Press, Tokyo. p. 253-283.

RoBinson, P.H. \& KenNelly, J.J. 1988. Influence of intake of rumen undegradable protein on milk production of 
late lactation Holstein cows. J. Dairy Sci. 71: 2135-2142.

-, SNIFFEN, C.J. \& VAN SOEST, P.J. 1985. Influence of level of feed intake on digestion and bacterial yield in the forestomachs of dairy cattle. Can. J. Anim. Sci. 65: 437444.

-, TAMminga, S. \& VAN VUUREN, A.M. 1987. Influence of declining level of feed intake and varying the proportion of starch in the concentrate on rumen ingesta quantity, composition and kinetics of ingesta turnover in dairy cows. Livest. Prod. Sci. 17: 37-62.

RodE, L.M. \& SATTER, L.D. 1988. Effect of amount and length of alfalfa hay in diets containing barley or corn on site of digestion and rumen microbial protein synthesis in dairy cows. Can. J. Anim. Sci. 68: 445-454.

RoHR, K. 1987. Present situation of the modern protein systems: Germany. In: Jarrige, R. \& Alderman, G. (eds.). Feed evaluation and protein requirement systems for ruminants. Proc. CEC seminar, Brussels. CEC L-2985 Luxembourg. p. 25-27.

ROOKE, J.A., RYMer, C., MAYA, F.M. \& ARMSTRONG, D.G. 1992. Effect of including barley or molassed sugar beet feed in grass silage diets on their digestion by cattle and sheep. J. Sci. Food Agric. 58: 475-483.

RoY, J.H.B., BalCh, C.C., Miller, E.L., Ørskov, E.R. \& SMrTH, R.H. 1977. Calculations of the N-requirements for ruminants from nitrogen metabolism studies. In: Protein metabolism and nutrition. Eur. Assoc. Anim. Prod. (EAAP), Publ. 22: 126-129.

RULQUIN, H. \& JoURNET, M. 1987. Efficiency of utilization of amino acids (AA) for lactation in ruminants. In: Jarrige, R. \& Alderman, G. (eds.). Feed evaluation and protein requirement systems for ruminants. Proc. CEC seminar, Brussels. CEC L-2985 Luxembourg. p. 213223.

SALO, M.-L. 1965. Determination of carbohydrate fractions in animal foods and faeces. Acta Agr. Fenn. 105: 1-102.

-, TUORI, M. \& KIISKINEN, T. 1982. Rehutaulukot ja ruokintanormit. Helsinki. 70 p.

SANCheZ, J.M. \& ClaypoOL, D.W. 1983. Canola meal as a protein supplement in dairy rations. J. Dairy Sci. 66: 8085.

SANG, J.P. \& SAlisbURY, P.A. 1988. Glucosinolate profiles of international rapeseed lines. J. Sci. Food Agric. 45: 225-261.

— \& TRuscotT, R.J. 1984. Liquid chromatographic determination of glucosinolates in rapeseed as desulphoglucosinolates. J. Assoc. Offic. Anal. Chem. 67: 829-833.

SARWAR, G., Bell, J.M., Sharby, T.F. \& Jones, J.D. 1981. Nutritional evaluation of meals and meal fractions derived from rape and mustard seed. Can. J. Anim. Sci. 61: 719-733.

SAS 1989. SAS Institute Inc. SAS/STAT User's guide, version 6, fourth edition, vol. 2. Gary, North Carolina, USA. $846 \mathrm{p}$.

SCHNUG, E. 1987. Eine Methode zur schnellen und einfachen Bestimmung des Gesamtglucosinolatgehaltes in
Grünmasse und Samen von Kruziferen durch die quantitative Analyse enzymatisch freisetzbaren Sulfates. Fat Sci. Technol. 89: 438-442.

- \& HANEKLAUS, S. 1988. Theoretical principles for the indirect determination of the total glucosinolate content in rapeseed and meal quantifying the sulphur concentration via X-ray fluorescence (X-RF method). J. Sci. Food Agric. 45: 243-254.

SCHWENKE, K.D. 1990. Structural studies on native and chemically modified storage proteins from rapeseed (Brassica napus L.) and related plant proteins. Nahrung 34: 225-240.

-, RAAB, B., UhLıG, J., TKOCZ, H., BEHLKE, J., BOTTGER, M. \& Freimuth, U. 1973a. Über Samenproteine. 3. Mitt. Isolierung und Charakterisierung der Albumine aus Sonnenblumen- und Rapssamen. Nahrung 17: 791-809.

-, Simo, B. \& RaAB, R. 1973b. Über Samenproteine. 2. Mitt. Fraktionenverteilung der Proteine aus Rapssamen. Nahrung 17: 579-586.

SETĂLÄ, J. 1983. The nylon bag technique in the determination of ruminal feed protein degradation. J. Scient. Agric. Soc. Finl. 55: 1-78.

— \& SYRJÄLÄ-Qvist, L. 1984/85. Degradation of crude protein and quality of undegradable protein in untreated or formaldehyde-treated rapeseed meal. Anim. Feed Sci. Technol. 12: 19-27.

Shahid, F. 1990a. Production and Canola: Global production and distribution. In: Shahidi, F. (ed.). Canola and rapeseed: production, chemistry, nutrition and processing technology. Van Nostrand Reinhold, New York. p. 3-13.

- 1990b. North American production of Canola. In: Shahidi, F. (ed.). Canola and rapeseed: production, chemistry, nutrition and processing technology. Van Nostrand Reinhold, New York. p. 15-23.

— \& NACZK, M. 1990. Removal of glucosinolates and other antinutrients from Canola and rapeseed by methanol/ammonia processing. In: Shahidi, F. (ed.). Canola and rapeseed: production, chemistry, nutrition and processing technology. Van Nostrand Reinhold, New York. p. 291-306.

Sharma, H.R., Ingalls, J.R. \& McKIRDY, J.A. 1977. Effects of feeding a high level of Tower rapeseed meal in dairy rations on feed intake and milk production. Can. J. Anim. Sci. 57: 653-662.

Sjaunja, L.O., Baevre, L., Junkkarinen, L., Pedersen. J. \& SETÄLÄ, J. 1990. A Nordic proposal for an energy corrected milk (ECM) formula. 27th Session International Committee of Recording and Productivity of Milk Animal. Paris, France. p. 156-157.

Sloan, B.K. Rowlinson, P. \& Armstrong, D.G. 1988. The influence of a formulated excess of rumen degradable protein or undegradable protein on milk production in dairy cows in early lactation. Anim. Prod. 46: 13-22.

SMALL, J.C. \& GoRdON, F.J. 1990. A comparison of the responses by lactating cows giwen grass silage to changes 
in the degradability or quantity of protein offered in the supplement. Anim. Prod. 50: 391-398.

SMITH, R.H. 1975. Nitrogen metabolism in the rumen and the composition and nutritive value of nitrogen compounds entering the duodenum. In: McDonald, I.W. \& Warner, A.C.I. (eds.). Digestion and metabolism in the ruminant. Proc. 4th Int. Symp. Ruminant Physiol. Sydney, Australia, p. 399-415.

SNedeCor, G.W. \& Cochran, W.G. 1980. Statistical methods. Seventh edition. The Iowa State University Press, Ames, Iowa, USA. 507 p.

SNIFFEn, C.J. \& RoBinson, P.H. 1987. Microbial growth and flow as influenced by dietary manipulations. J. Dairy sci. 70: $425-441$.

SomogYl, M. 1945. A new reagent for the determination of sugars. J. Biol. Chem. 160: 61-68.

Sørensen, H. 1990. Glucosinolates: Structure-PropertiesFunction. In: Shadidi, F. (ed.). Canola and rapeseed: production, chemistry, nutrition and processing technology. Van Nostrand Reinhold, New York. p. 149-172.

SPÖRNDLY, E. 1986. Effects of diet to dairy cows on milk protein content. Rep. 159. Swed. Univ. Agric. Sci. Uppsala, Sweden. 24 p.

- 1989. Effects of diet on milk composition and yield of dairy cows with special emphasis on milk protein content. Swed. J. Agric. Res. 19: 99-106.

Summers, J.D. \& LeEson, S. 1985. Mineral profile of Canola and soybean meal. Can. J. Anim. Sci. 65: 913919.

-, Bong, D.L. \& Leeson, S. 1983. Sodium, potassium and phosphorus in canola and soybean meal. Nutr. Rep. Int. 28: 955-963.

SuVITIE, M. \& RinNE, K. 1988. Effect of supplementing grain concentrate with rapeseed meal on milk production and milk composition with dairy cows on grass silage or hay based feeding. Polish-Finnish seminar on "Nutritive value and utilization of rape seeds protein and other plant protein in animal feeding", 13.-14. 12.1988, Jablonna, Warsaw. Mimeogr. 14 p.

SYrJÄLÄ-Qvist, L., TUORI, M. \& SETÄLÄ, J. 1982. Rape seed meal as a protein source for high-production dairy cows on grass silage- and hay-based feeding. J. Scient. Agric. Soc. Finl. 54: 145-153.

Syrjälä, L., Poutiainen, E. \& Koskela, V.-H. 1978. Untreated and formaldehyde treated skimmilk powder as a protein supplement for dairy cows. J. Scient. Agric. Soc. Finl. 50: 155-165.

TAMMINGA, S. 1981. Effect of the roughage/concentrate ratio on nitrogen entering the small intestine of dairy cows. Neth. J. Agric. Sci. 29: 273-283.

-, Robinson, P.H., Vogt, M. \& BoeR, H. 1989. Rumen ingesta kinetics of cell wall components in dairy cows. Animal Feed Sci. Technol. 25: 89-98.

Tesfa, A.T. 1992. Rapeseed oil in ruminants diet: its effect on rumen metabolism and animal performance. Diss. Univ. Helsinki, Dept. Anim. Sci. 53 p.
-, TUORI, M. \& SYrJÄLÄ-Qvist, L. 1991. Replacement of grain by tallow or rapeseed oil in the diet of lactating cows and its effects on milk yield and composition. Finn. J. Dairy Sci. 49: 54-64.

ThEANDER, O. \& ÅmAN, P. 1976. Low-molecular carbohydrates in rapeseed and turnip rapeseed meals. Swed. J. Agric. Res. 6: 81- 85.

-, Åman, P., Miksche, G.E. \& Yasuda, S. 1977. Carbohydrates, polyphenols, and lignin in seed hulls of different colors from turnip rapeseed. J. Agric. Food Chem. 25: 270-273.

THIES, W. 1976. Quantitative gas liquid chromatography of glucosinolates in a microliter scale. Fette Seifen Anstrichmittel 78: 231-234.

- 1982. Complex-formation between glucosinolates and tetrachloropalladate (II) and its utilization in plant breeding. Fette Seifen Anstrichmittel. 84: 338-342.

Thomas, C. \& RAE, R.C. 1988. Concentrate supplementation of silage for dairy cows. In: Garnsworthy, P.C. (ed.). Nutrition and lactation in the dairy cow. Butterworths. p. 327-354.

Thomas, P.C., Chamberlain, D.G., Robertson, S., ShaMOON, S.A. \& WATSON, J.N. 1984. The effect of the source and level of protein supplement on milk production in dairy cows given silage diets. In: Gordon, F.J. \& Unsworth, E.F. (eds.). Seventh silage conference. Silage production \& utilization. Summary of papers. p. 45-46.

Tномке, S. 1981. Review of rapeseed meal in animal nutrition: ruminant animals. J. Am. Oil Chem. Soc. 58: 805810.

Thompson, L. 1990. Phytates in Canola/rapeseed. In: Shadidi, F. (ed.). Canola and rapeseed: production, chemistry, nutrition and processing technology. Van Nostrand Reinhold, New York. p. 173-192.

ThuEN, E. \& VIK-Mo, L. 1985. Comparison of three systems for protein evaluation on the basis of production experiments in lactating dairy cows. Acta Agric. Scand. Suppl. 25: 155-162.

Tilley, J.M.A. \& TerRy, R.A. 1963. A two-stage technique for in vitro digestion of forage crops. J. Br. Grassl. Soc. 18: 104-111.

Toepher International 1990. Statistische Informationen zum Getreide- und Futtermittelmarkt. Toepher International, Hamburg. p. 50-52.

TUORI, M. \& SYRJĀLÄ-QvisT, L. 1987. Heat-moisture treated rapeseed meal as a protein supplement for dairy cows. Proc. 7th Int. Rapeseed Congr., Poznan, Poland. Vol 7: 1836.

- \& SYRJÄLÄ-QvisT, L. 1988. Effect of supplementing grain concentrate with rapeseed meal on the digestibility and $\mathrm{N}$ - utilization with dairy cows on grass silage or hay based feeding. Polish-Finnish seminar on "Nutritive value and utilization of rape seeds protein and other plant protein in animal feeding", 13.-14.12.1988, Jablonna, Warsaw. Mimeogr 3 p. 
UNDERHILL, E.W. \& KIRKLAND, D.F. 1971. Gas chromatography of trimehylsilylderivatives of glucosinolates. J. Chromatogr. 57: 47-54.

UNGER, E.H. 1990. Commercial processing of Canola and rapeseed: crushing and oil extraction. In: Shahidi, F. (ed.). Canola and rapeseed: production, chemistry, nutrition and processing technology. Van Nostrand Reinhold, New York. p. 235-249.

VALLE, O. 1953. Kotimainen kasviöljyn tuotanto: Öljykasvien viljelymme nykyinen vaihe. [Present status of the growing oil plants in Finland, English abstr.]. J. Industr. Chem. 10: 147- 150.

Valtion maatalouskemian laitos. 1989. Reports of the State Institute of Agricultural Chemistry with English Summary. Vantaa, Helsinki, 103 p.

VAN ES, A.J.H. 1978. Feed evaluation for ruminants. I. The systems in use from May onwards in the Netherlands. Livest. Prod. Sci. 5: 331-345.

Van Keulen, J. \& Young, B.A. 1977. Evaluation of acidinsoluble ash as a natural marker in ruminant digestibility studies. J. Anim. Sci. 44: 282-287.

Vanhatalo, A. \& Aronen, I. 1991. The ruminal and intestinal degradation estimates of either untreated or physically treated rapeseed meals measured by nylon bag techniques. Proc. 8th International rapeseed congress "Rapeseed in a changing world", Saskatoon, Canada. p. 424-429.

VARVIKKO, T. 1986. Evaluation of rumen-undegraded feed protein. Diss. Dept. Anim. Husbandry, Agric. Res. Centre, Jokioinen, Finland. 28 p.

— \& LiNDBERG, J.E. 1985. Estimation of microbial nitrogen in nylon-bag residues by feed $15_{\mathrm{N}}$ dilution. Br. J. Nutr. 54: 473-481.

— \& VANHATALO, A. 1988. Intestinal nitrogen degradation in sacco of hay and grass silage. Proc. VI World Conf. Anim. Prod. 1988, Helsinki, Finland. p. 359.

- \& Vanhatalo, A. 1990. The effect of differing types of cloth and of contamination by non-feed nitrogen on intestinal digestion estimates using porous syntheticfibre bags in a cow. Br. J. Nutr. 63: 221-229.

— \& VANHATALO, A. 1991. Intestinal nitrogen degradation of hay and grass silage estimated by the mobile bag technique. World Rev. Anim. Prod. 26: 73-76.

VÉrITÉ, R. \& JoURNET, M. 1977. Utilisation des tourteaux traités au formol par les vaches laitières. II. Effets sur la production laitière du traitement des tourteaux et du niveau d'apport azoté au début de la lactation. Ann. Zootech. 26: 183-205.

— \& PeYraud, J.-L. 1989. Protein: the PDI systems. In: Jarrige, R. (ed.). Ruminant nutrition. Recommended allowances \& feed tables. INRA, Paris, 1989. p. 33-47.

-, JourNet, M. \& JARRIGE, R. 1979. A new system for the protein feeding of ruminants: the PDI system. Livest. Prod. Sci. 6: 349-367.

VIK-Mo, L. 1985. Merits of new protein evaluation principles applied to Norwegian dairy diets. Acta Agric. Scand.
Suppl. 25: 200-211.

VILKKI, J. 1991. Kulta-kevätrypsi. Maatalouden tutkimuskeskus, Tiedote 3/91, $22 \mathrm{p}$.

Vilva, V. 1989. WSYS statistical program. Dept. Anim. Breed. Univ. Helsinki.

VINCENT, I. \& HILL, R. 1988. Low-glucosinolate rapeseed meal as a protein source for milk production. Anim. Prod. 46: 505-506 (abstr.).

Vincent, I.C., Hill, R. \& CAmpling, R.C. 1990. A note on the use of rapeseed, sunflower and soya-bean meals as protein sources in compound foods for milking cattle. Anim. Prod. 50: 541-543.

VIRTANEN, A. I. 1963. An introduction to studies on factors in food- and fodder-plants which disturb the function of the thyroid gland, the transfer of these factors to milk by the cow, and the alleged goitogecic properties of milk. In: Virtanen, A.I. (ed.). Final report on investigations on the alleged goitrogenic properties of milk. Biochemical Inst., Helsinki. p. 1-26.

-, Kreula, M. \& KiesvaAra, M. 1959. On the transfer of L-5-vinyl-2-thiooxazolidone from the rumen to the milk. Acta Chem. Scand. 13: 1043-1044.

Volgt, J. \& PIATKowsKi, B. 1991. Stickstoffumsatz im Verdauungstrakt von Milchkühen. 42nd Ann. Meet. EAAP, Berlin, Germany. p. 442.

-, Platkowski, B., Engelmann, H. \& Rudolph, E. 1985. Measurement of the postruminal digestibility of crude protein by the bag technique in cows. Arch. Tierernähr. 35: 555-562.

Volden, H., Harstad, O.M. \& Henne, M. 1992. Praktisk utprøving av nytt proteinvurderingssystem. Forsøk på landbrukskoler. In: Husdyrforsoksmotet, Norges landbrukshogskole. SFFL, Faginfo no. 13 1992, Ảs, Norway. p. 567-582.

WALDERN, D.E. 1973. Rapeseed meal versus soybean meal as the only protein supplement for lactating cows fed corn silage roughage rations. Can. J. Anim. Sci. 53: 107112.

WARD, J.T., BASFORD, W.D., HAWKINS, J.H. \& HollidAY, J.M. 1985. Oilseed rape. Farming Press LTD,Ipswich. 298 p.

WeBSTER, A.J.F. 1987. Metabolizable protein - the U.K. approach. In: Jarrige, R. \& Alderman, G. (eds.). Feed evaluation and protein requirement systems for ruminants. Proc. CEC seminar, Brussels. CEC L-2985 Luxembourg. p. 47-53.

WEBSTER, J. 1992. Metabolizable protein: the new UK feeding system for ruminants. Int. Milling Flour Feed 1992, May: 22-23.

WeisbJerg, M.R., Bhargava, P.K., Hvelplund, T. \& MADSEN, J. 1990. Anvendelse af nedbrydningsprofiler i fodermiddelvurderingen (Summary: Use of degradation curves in feed evaluation). Beretn. 679 fra Statens Husdyrbrugsforsøg. 33 p.

ZADERNOWSKI, R. \& SosULSKI, F. 1978. Composition of total lipids in rapeseed. J. Am. Oil Chem. Soc. 55: 870-872. 


\title{
SELOSTUS
}

\section{Rypsirouhe lypsylehmien valkuaisrehuna säilörehuvaltaisella ruokinnalla}

\author{
MIKKO TUORI \\ Helsingin yliopisto
}

Lypsylehmien väkirehun täydentämistä rypsirouheella tutkittiin viidessă ruokintakokeessa tuoresăilörehuun perustuvalla ruokinnalla. Rypsirouheen osuus văkirehuseoksessa vaihteli 0-33 \% loppuosan ollessa ohran ja kauran seosta. Yhdessä kokeessa oli mukana samat koejäsenet sekä rypsirouheesta ettă soijarouheesta, ja toisessa kokeessa säilörehu tai samalla kasvuasteella korjattu latokuivattu heină. Lisăksi tehtiin laskelmia rypsirouheen vaikutuksesta maitotuotokseen aineistosta, johon oli kerätty Suomessa viime vuosina tehdyt rypsivertailukokeet. Valkuaisen hyväksikăyttöă tarkasteltiin pohjoismaisen AAT-PBV -valkuaisjärjestelmän mukaan.

Tutkimusaikana rypsilajikkeet muuttuivat runsaasti glukosinolaatteja (40-50 $\mu$ moolia per g rasvatonta rouhetta) sisăltävistă 0 -lajikkeista 00 -lajikkeisiin, joiden glukosinolaattipitoisuus aleni noin kolmannekseen. Rypsirouheen lämpökäsittely Öpex-menetelmällä alensi rouheen glukosinolaattipitoisuuden edelleen noin puoleen.

Kun viljaa korvattiin rypsirouheella (maks. $1.7 \mathrm{~kg} \mathrm{KA} / \mathrm{d}$ ) săilörehun ollessa ad libitum, săilörehun syönti lisăăntyi keskimäärin $0.43 \mathrm{~kg} \mathrm{KA}$ per kg rypsirouheen kuiva-aineen lisäystă (n.s.). Vaikutus maitotuotokseen oli keskimäärin $0.77 \mathrm{~kg} \quad(\mathrm{P}<0.02)$ ja energiakorjattuun maitotuotokseen (ECM) $0.70 \mathrm{~kg}$ per $\mathrm{kg}$ rypsirouheen kuiva-aineen lisäystă $(\mathrm{P}<0.02)$. Rypsirouheen sisällyttäminen văkirehuun 12-16 $\%$ lisäsi tuotosta, mutta osuuden noustessa edelleen $24 \%$ :iin vaikutus oli văhăinen. Maidon valkuaispitoisuuteen vaikutti merkitsevästi muuntokelpoisen energian saannin lisăys, valkuaispitoisuus nousi $0.07 \mathrm{~g} / \mathrm{kg}$ per MJ ME:n lisăystă $(\mathrm{P}<0.02)$.

Rypsirouheen Öpex-käsittely (kostea kuumennus) lisäsi maitotuotosta merkitsevăsti yhdessä kokeessa (21.9 vs. 23.9 $\mathrm{kg}$ maitoa tai 23.4 vs. $25.2 \mathrm{~kg} \mathrm{ECM} / \mathrm{d}),(\mathrm{P}<0.03)$. Kahdessa muussa kokeessa käsittelyllă ei ollut vaikutusta maitotuotokseen. Soijarouheella ja rypsirouheella ei ollut eroa vaikutuksessa maitotuotokseen, kun rouheita syötettiin sama määrä raakavalkuaisena mitattuna.

Maidon goitriinipitoisuus aleni rypsilajikkeiden glukosinolaattipitoisuuden ja rypsirouheen mäărăn alentuessa. Käytettåessä Öpex-kăsiteltyjă 00-rypsirouheita maidon goitriinipitoisuus oli enăă alle $10 \mu \mathrm{g} / \mathrm{l}$ (analyysin herkkyysraja 2 $\mu \mathrm{g} / \mathrm{l})$.

AAT:n hyvăksikăyttöă maidontuotannossa estimoitiin käyttämăllă erilaisia vakioita AAT-PBV -arvojen laskemisessa. Hyvăksikăytőn vaihtelukerroin aleni, kun laskennallisesti lisättiin mikrobivalkuaisen osuutta AAT:stä. Tăhăn suuntaan vaikuttavat mikrobi-N kontaminaation huomioiminen in sacco määrityksessä, pötsin virtausvakion alentaminen 0.08:sta 0.03:een ja mikrobivalkuaissynteesin tehokkuuden lisaaăminen. Paras malli saatiin laskemalla mikrobivalkuaissynteesin tehokkuus VoIGT ja PIATKOWSKIn (1991) mukaan. 
AAT-PBV feed protein evaluation system, calculation of feed values and requirements

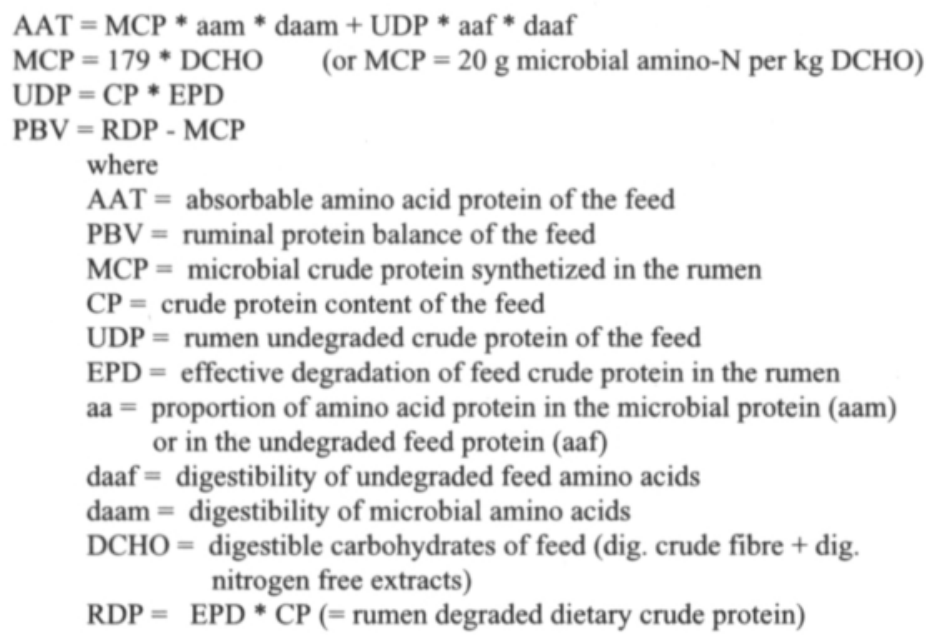

Constants:

Proportion of amino acid protein in absorbable crude protein:

- 0.70 in microbial crude protein

-0.85 in undegraded concentrate crude protein

-0.65 in undegraded roughage crude protein

Digestibility of amino acids (AA):

-0.85 for AA from microbial crude protein

-0.82 for AA from undegraded feed crude protein (UDP)

Digestibility of UDP can be estimated by using the

equation of HVELPLUND \& MADSEN (1990):

TD $=($ UDP-TU $) /$ UDP

where TD $=$ true digestibility of UDP in the small intestine

$\mathrm{TU}=$ fraction of true indigestible crude protein of the feed

TU should be determined by using the mobile nylon bag technique, and if not determined, value of 0.05-0.07 can be used.

Calculation of EPD value for feeds according to ØRSKOV \& MCDONALD (1979):

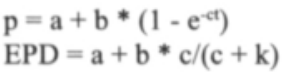

where $p=$ measured bag degradation of protein at time $t$

$a=$ rapid degraded fraction of protein

$\mathrm{b}=$ slow degraded fraction

$c=$ degradation rate of fraction $b$

$k=$ fractional outflow rate

$\mathrm{EDP}=$ effective degradation of protein 
Recommendations of AAT values for dairy cattle:

Requirements of AAT are from MADSEN (1985) and later revised by Nordic protein group (HvELPLUND 1990). Requirement for maintenance is $3.25 \mathrm{~g} \mathrm{AAT}^{*} \mathrm{~W}^{0.75}$. For the milk production the recommendation was $45 \mathrm{~g} / \mathrm{kg}$ ECM (MADSEN 1985), now $40 \mathrm{~g} / \mathrm{ECM}$ (energy corrected milk yield, SJAUNJA et al. 1990), variation $37-42 \mathrm{~g}$. At production levels below $25 \mathrm{~kg}$ ECM per day a decrease of 3-4 g AAT per kg ECM may be justified ((HVELPLUND 1990).

In Denmark the AAT-concentration of the diet can be expressed as $97 \mathrm{~g} \mathrm{AAT} /$ feed unit for high producing, decreasing to about $90 \mathrm{~g} \mathrm{AAT}$ /FU for low producing cows. In Norway AAT-recommendation (VoLDEN et al. 1992) is:

$$
\begin{gathered}
\mathrm{AAT}, \mathrm{g} / \mathrm{kg} \mathrm{ECM}=\left(40 * \mathrm{ECM}+0.2 * \mathrm{ECM}^{2}\right) / \mathrm{ECM} \\
=40+0.2 * \mathrm{ECM}^{*}
\end{gathered}
$$

Additional requirement for pregnancy is 60,100 and $172 \mathrm{~g} \mathrm{AAT} / \mathrm{d}$ at the 7 th, 8 th and 9 th month of pregnancy.

The ideal PBV value should be 0 , but minimum value of $-200 \mathrm{~g} / \mathrm{d}$ for high producing and $-300 \mathrm{~g} / \mathrm{d}$ for low producing cows can be accepted. As maximum PBV-value $900 \mathrm{~g} / \mathrm{d}$ is accepted in Denmark ((HvELPLUND 1990) but there is no recommendation in Norway (VoLdEN et al. 1992). 
Composition of feeds in experiments 1 and 2

\begin{tabular}{lllll} 
DM & \multicolumn{2}{l}{ In dry matter (\%) } & & \\
$(\%)$ & Ash & Crude & Ether & Crude \\
& & protein & extract & fibre
\end{tabular}

\begin{tabular}{lrrrrr}
\hline Experiment 1 & & & & & \\
Silage & 24.9 & 7.4 & 16.3 & 5.6 & 28.3 \\
Hay & 83.8 & 6.3 & 7.7 & 2.2 & 35.4 \\
Barley & 75.6 & 2.5 & 10.1 & 2.3 & 5.8 \\
Oat & 82.4 & 3.5 & 11.7 & 5.4 & 12.2 \\
RSM & 88.6 & 7.4 & 35.4 & 9.3 & 12.8 \\
RSM-heated & 86.3 & 7.5 & 40.5 & 4.5 & 14.6 \\
Experiment 2 & & & & & \\
Silage & 22.5 & 6.6 & 16.8 & 6.4 & 30.3 \\
Hay & 83.5 & 6.5 & 9.6 & 2.1 & 34.3 \\
Barley & 75.1 & 2.3 & 11.4 & 2.3 & 5.2 \\
Oat & 87.4 & 3.1 & 13.3 & 5.5 & 10.8 \\
RSM0 & 88.0 & 8.0 & 36.2 & 6.7 & 12.5 \\
RSM0-Öpex & 88.0 & 8.0 & 35.7 & 6.9 & 13.0 \\
\hline
\end{tabular}

RSM = turnip rapeseed meal (0-var.), RSM-heated = dry heated rapeseed meal; RSM-Öpex = heat-moisture treated turnip rapeseed meal (0-var.)

Composition of feeds in experiment 3

\begin{tabular}{|c|c|c|c|c|c|c|c|c|}
\hline & \multirow{2}{*}{$\begin{array}{l}\text { DM } \\
(\%)\end{array}$} & \multicolumn{2}{|c|}{ In dry matter (\%) } & \multirow[b]{2}{*}{$\begin{array}{l}\text { Ether } \\
\text { extract }\end{array}$} & \multirow[b]{2}{*}{$\begin{array}{l}\text { Crude } \\
\text { fibre }\end{array}$} & \multirow[b]{2}{*}{ NDF } & \multirow[b]{2}{*}{$\mathrm{ADF}$} & \multirow[b]{2}{*}{$\mathrm{ADL}$} \\
\hline & & Ash & $\begin{array}{l}\text { Crude } \\
\text { protein }\end{array}$ & & & & & \\
\hline Silage & 20.9 & 6.8 & 18.5 & 5.4 & 27.3 & 49.7 & 29.4 & 1.7 \\
\hline Barley & 87.3 & 3.0 & 12.7 & 3.7 & 5.2 & 20.9 & 5.5 & 0.4 \\
\hline Oat & 88.6 & 3.2 & 11.5 & 7.0 & 10.8 & 27.3 & 12.4 & 2.2 \\
\hline RSM00-Öpex & 88.2 & 8.0 & 33.3 & 10.7 & 12.1 & 27.2 & 17.4 & 7.4 \\
\hline RSM0 & 88.5 & 7.7 & 33.4 & 10.2 & 12.9 & 28.2 & 18.9 & 8.6 \\
\hline $\mathrm{RSM} 00-\mathrm{FeSO}_{4}$ & 88.8 & 8.1 & 33.3 & 11.5 & 12.1 & 25.7 & 16.5 & 6.9 \\
\hline
\end{tabular}

RSM0 = turnip rapeseed meal (0-var.); RSM00-Öpex = heat-moisture treated turnip rapeseed meal (00-var.); RSM00-FeSO4 = turnip rapeseed meal (00-var.), glucosinolate content is reduced by ferrosulphate treatment.

Composition of feeds in experiment 4.

\begin{tabular}{|c|c|c|c|c|c|c|c|c|}
\hline & \multirow{2}{*}{$\begin{array}{l}\text { DM } \\
(\%)\end{array}$} & \multicolumn{2}{|c|}{ In dry matter $(\%)$} & \multirow[b]{2}{*}{$\begin{array}{l}\text { Ether } \\
\text { extract }\end{array}$} & \multirow[b]{2}{*}{$\begin{array}{l}\text { Crude } \\
\text { fibre }\end{array}$} & \multirow[b]{2}{*}{ NDF } & \multirow[b]{2}{*}{$\mathrm{ADF}$} & \multirow[b]{2}{*}{$\mathrm{ADL}$} \\
\hline & & Ash & $\begin{array}{l}\text { Crude } \\
\text { protein }\end{array}$ & & & & & \\
\hline Silage & 21.9 & 6.6 & 16.6 & 5.3 & 31.0 & 56.2 & 33.0 & 2.2 \\
\hline Hay & 87.5 & 9.0 & 18.0 & 2.4 & 29.5 & 58.6 & 30.6 & 2.4 \\
\hline Barley & 87.0 & 2.4 & 11.7 & 2.6 & 4.9 & 19.9 & 5.2 & 0.8 \\
\hline Oat & 88.7 & 2.7 & 12.9 & 7.0 & 9.3 & 23.5 & 10.3 & 1.9 \\
\hline RSM00-Öpex & 87.2 & 8.0 & 32.7 & 9.4 & 13.7 & 25.6 & 17.9 & 7.0 \\
\hline
\end{tabular}

RSM-Öpex = heat-moisture treated turnip rapeseed meal (00-variety); hay is cut at the same maturity as silage 
Composition of feeds in experiment 5

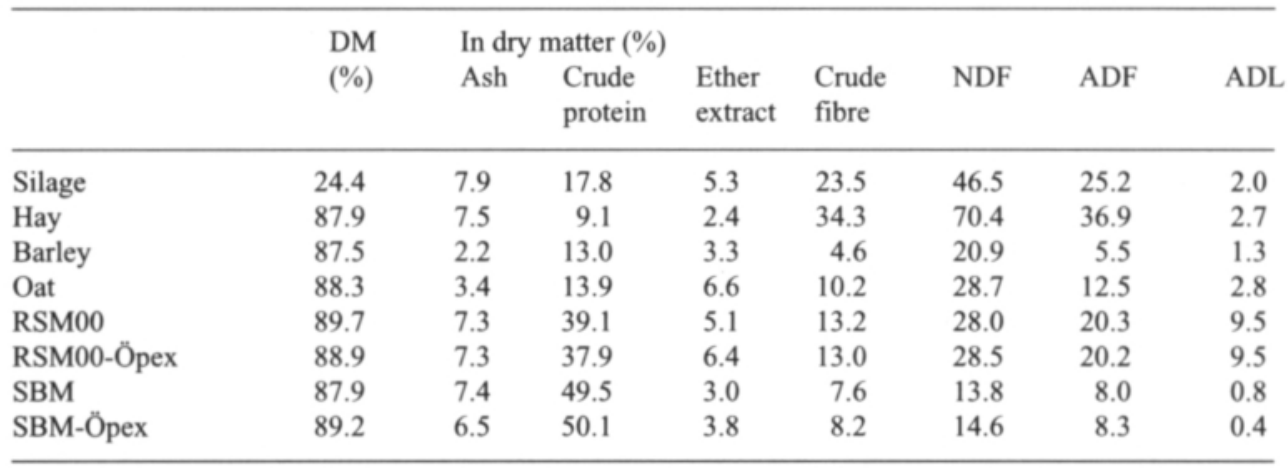

RSM = turnip rapeseed meal (00-var.); RSM-Öpex = heat-moisture treated turnip rapeseed meal (00-var.);

$\mathrm{SBM}=$ soybean meal

Energy values of the feeds in experiments 1-5

\begin{tabular}{|c|c|c|c|c|c|c|c|c|c|c|c|c|c|c|c|}
\hline & \multicolumn{3}{|l|}{ Exp. 1} & \multicolumn{3}{|c|}{ Exp. 2} & \multicolumn{3}{|c|}{ Exp. 3} & \multicolumn{3}{|c|}{ Exp. 4b } & \multicolumn{3}{|l|}{ Exp. 5} \\
\hline & FFU & $\mathrm{ME}$ & NEL & FFU & ME & NEL & FFU & $\mathrm{ME}$ & NEL & FFU & ME & NEL & FFU & ME & NEL \\
\hline Silage & 0.730 & 10.30 & 5.67 & 0.742 & 10.47 & 5.79 & 0.735 & 10.39 & 5.78 & 0.771 & 10.88 & 6.04 & 0.791 & 11.18 & 6.32 \\
\hline Hay & 0.519 & 8.77 & 4.94 & 0.554 & 9.07 & 5.12 & & & & 0.692 & 10.14 & 5.90 & 0.611 & 9.69 & 5.51 \\
\hline Barley & 1.166 & 13.61 & 7.97 & 1.163 & 13.59 & 7.96 & 1.172 & 13.69 & 8.06 & 1.173 & 13.70 & 8.04 & 1.158 & 13.53 & 7.92 \\
\hline Oat & 0.950 & 11.53 & 6.61 & 1.036 & 12.32 & 7.17 & 1.080 & 12.59 & 7.38 & 1.072 & 12.78 & 7.51 & 1.053 & 12.54 & 7.35 \\
\hline RSM & 1.088 & 12.96 & 7.57 & 0.983 & 11.82 & 7.03 & 1.063 & 12.40 & 7.48 & & & & 0.960 & 11.59 & 6.84 \\
\hline RMS-Öpex ${ }^{1)}$ & 1.065 & 12.56 & 7.61 & 0.984 & 11.82 & 7.03 & 1.072 & 12.51 & 7.57 & 1.019 & 12.15 & 7.29 & 0.981 & 11.81 & 7.01 \\
\hline $\mathrm{RSM}_{-} \mathrm{FeSO}_{4}$ & & & & & & & 1.082 & 12.63 & 7.67 & & & & & & \\
\hline SBM & & & & & & & & & & & & & 1.056 & 12.46 & 7.48 \\
\hline SBM-Öpex & & & & & & & & & & & & & 1.069 & 12.58 & 7.56 \\
\hline
\end{tabular}

1) In experiment 1 dry heat-treated RSM

Average rumen degradability of the feed protein in experiments 3-5.

\begin{tabular}{|c|c|c|c|c|c|c|c|c|c|}
\hline \multirow{2}{*}{\multicolumn{2}{|c|}{$\begin{array}{l}\text { No of } \\
\text { analysis }\end{array}$}} & \multirow{2}{*}{$\begin{array}{l}\text { Water } \\
\text { soluble }\end{array}$} & \multirow{2}{*}{$\begin{array}{l}\text { Washing } \\
\text { loss }\end{array}$} & \multicolumn{2}{|c|}{ Incubation time, hrs } & \multirow[b]{2}{*}{12} & \multirow[b]{2}{*}{24} & \multirow[b]{2}{*}{48} & \multirow[b]{2}{*}{72} \\
\hline & & & & 3 & 6 & & & & \\
\hline Silage & 13 & & 60.6 & 63.8 & 70.1 & 81.1 & 86.2 & 90.0 & 91.3 \\
\hline Hay & 1 & & 47.3 & 48.3 & 50.4 & 62.0 & 79.1 & 80.9 & 85.8 \\
\hline Hay(e) & 4 & & 56.3 & 54.8 & 59.8 & 73.5 & 79.8 & 85.2 & 85.8 \\
\hline Barley & 9 & 15.3 & 41.9 & 56.0 & 66.4 & 88.3 & 91.9 & 95.4 & 96.3 \\
\hline Oat & 9 & 14.7 & 80.0 & 84.3 & 88.1 & 93.6 & 94.6 & 94.9 & 95.0 \\
\hline RSM & 12 & 11.2 & 18.5 & 36.0 & 47.3 & 74.0 & 88.4 & 92.2 & 92.8 \\
\hline RSMtr & 11 & 9.7 & 14.7 & 31.8 & 46.2 & 70.7 & 84.7 & 91.3 & 92.4 \\
\hline SBM & 2 & 13.4 & 24.5 & 40.8 & 40.2 & 60.3 & 93.2 & 99.1 & 99.3 \\
\hline SBMtr & 2 & 8.7 & 20.0 & 23.0 & 26.3 & 43.8 & 66.6 & 97.9 & 99.2 \\
\hline
\end{tabular}


Feed intake and milk production in trial 1 (means of least squares of the lactation weeks of 4-14)

\begin{tabular}{|c|c|c|c|c|c|c|}
\hline & $\begin{array}{l}\text { Treatments } \\
\text { Control }\end{array}$ & RSM1 & RSM2 & TRSM1 & S.E. & $\begin{array}{r}\text { Significance } \\
\text { (P-value) }\end{array}$ \\
\hline \multicolumn{7}{|l|}{ DM intake $(\mathrm{kg} / \mathrm{d})$} \\
\hline Forage & 9.92 & 10.15 & 9.90 & 10.21 & 0.97 & 0.92 \\
\hline Grain & 5.73 & 4.62 & 3.49 & 4.30 & 0.22 & \\
\hline RSM & & 1.40 & 2.10 & 1.25 & 0.11 & \\
\hline Total & 15.87 & 16.39 & 15.70 & 15.98 & 1.12 & 0.78 \\
\hline \multicolumn{7}{|l|}{ Milk production } \\
\hline Milk (kg/d) & 24.36 & 26.78 & 23.89 & 26.68 & 2.98 & 0.24 \\
\hline $\operatorname{ECM}(\mathrm{kg} / \mathrm{d})$ & 26.06 & 26.96 & 24.91 & 27.18 & 2.57 & 0.43 \\
\hline Fat $(\mathrm{g} / \mathrm{d})$ & 1176 & 1173 & 1102 & 1182 & 126 & 0.66 \\
\hline Protein $(\mathrm{g} / \mathrm{d})$ & 752 & 797 & 736 & 815 & 66 & 0.18 \\
\hline \multicolumn{7}{|l|}{ Milk composition } \\
\hline Fat $(\mathrm{g} / \mathbf{k g})$ & 48.4 & 44.3 & 46.0 & 44.2 & 4.0 & 0.27 \\
\hline Protein $(\mathrm{g} / \mathbf{k g})$ & 30.9 & 30.2 & 30.9 & 30.6 & 1.8 & 0.92 \\
\hline Urea $(\mathrm{mg} / 100 \mathrm{ml})$ & 24.3 & 32.1 & 34.4 & 27.8 & 2.9 & $<0.001$ \\
\hline Live weight (kg) & 523.7 & 511.9 & 522.0 & 537.8 & 58.0 & 0.94 \\
\hline $\begin{array}{l}\text { Live weight change } \\
\text { (kg/d) }\end{array}$ & -0.15 & -0.02 & 0.08 & -0.06 & 0.31 & 0.65 \\
\hline $\mathrm{CP}$ intake (g/d) & 2204 & 2606 & 2635 & 2538 & 177 & 0.003 \\
\hline \multicolumn{7}{|l|}{ Energy intake } \\
\hline $\mathrm{ME}(\mathrm{MJ} / \mathrm{d})$ & 173.7 & 179.9 & 170.8 & 172.8 & 11.8 & 0.66 \\
\hline NEL (MJ/d) & 98.0 & 101.8 & 96.9 & 97.5 & 6.6 & 0.66 \\
\hline FFU/d & 13.14 & 13.65 & 12.91 & 13.00 & 0.85 & 0.55 \\
\hline \multicolumn{7}{|l|}{ Feed conversion } \\
\hline FFU/kg ECM & 0.33 & 0.35 & 0.34 & 0.31 & 0.037 & 0.54 \\
\hline $\begin{array}{l}\text { FFU/kg ECM } \\
\text { (with LWC) }\end{array}$ & 0.34 & 0.34 & 0.33 & 0.31 & 0.021 & 0.18 \\
\hline \multicolumn{7}{|l|}{ Utilization of ME } \\
\hline kl & 0.68 & 0.66 & 0.67 & 0.72 & 0.059 & 0.47 \\
\hline kl (with LWC) & 0.65 & 0.68 & 0.69 & 0.73 & 0.052 & 0.20 \\
\hline
\end{tabular}

RSM = turnip rapeseed meal (0-var.); TRSM = heat-treated rapeseed meal (00-var.); ECM = energy corrected milk (SJAUNJA et al. 1990); ME = metabolizable energy (MAFF 1975), NEL = net energy in lactation (VAN Es 1978); $\mathrm{CP}=$ crude protein; $\mathrm{FFU}=$ fattening feed unit $(0.7 \mathrm{~kg}$ starch); $\mathrm{kl}=$ utilization of $\mathrm{ME}$ in lactation (ARC 1980), LWC $=$ live weight change $(\mathrm{kg} / \mathrm{d})$ 
Feed intake and milk production in trial 2 (means of least squares)

\begin{tabular}{|c|c|c|c|c|}
\hline & \multicolumn{2}{|c|}{ Treatments } & \multicolumn{2}{|c|}{ Significance } \\
\hline & RSM & TRSM & S.E. & (P-value) \\
\hline \multicolumn{5}{|l|}{ DM intake (kg/d) } \\
\hline Forage & 9.32 & 8.89 & 0.69 & 0.14 \\
\hline Grain & 4.95 & 5.28 & 0.87 & 0.37 \\
\hline RSM & 1.08 & 1.15 & 0.18 & 0.36 \\
\hline Total & 15.58 & 15.55 & 1.27 & 0.97 \\
\hline \multicolumn{5}{|l|}{ Milk production } \\
\hline Milk (kg/d) & 21.91 & 23.90 & 1.96 & 0.021 \\
\hline ECM (kg/d) & 23.35 & 25.16 & 1.81 & 0.023 \\
\hline Fat $(g / d)$ & 1036 & 1113 & 93 & 0.055 \\
\hline Protein (g/d) & 697 & 750 & 53 & 0.024 \\
\hline \multicolumn{5}{|l|}{ Milk composition } \\
\hline Fat $(\mathrm{g} / \mathrm{kg})$ & 47.4 & 47.3 & 2.8 & 0.88 \\
\hline Protein $(\mathrm{g} / \mathrm{kg})$ & 31.9 & 31.6 & 1.2 & 0.49 \\
\hline Urea $(\mathrm{mg} / 100 \mathrm{ml}$ & l) 35.3 & 36.7 & 4.8 & 0.48 \\
\hline Live weight (kg) & 502.3 & 489.6 & 51.0 & 0.55 \\
\hline $\begin{array}{l}\text { Live weight change } \\
(\mathrm{kg} / \mathrm{d})\end{array}$ & 0.12 & 0.09 & 0.17 & 0.65 \\
\hline $\mathrm{CP}$ intake, $(\mathrm{g} / \mathrm{d})$ & 2528 & 2532 & 237 & 0.97 \\
\hline \multicolumn{5}{|l|}{ Energy intake } \\
\hline $\mathrm{ME}(\mathrm{MJ} / \mathrm{d})$ & 171.8 & 172.7 & 15.3 & 0.89 \\
\hline NEL (MJ/d) & 97.4 & 98.0 & 8.8 & 0.86 \\
\hline FFU/d & 13.14 & 13.29 & 1.25 & 0.77 \\
\hline \multicolumn{5}{|l|}{ Feed conversion } \\
\hline FFU/kg ECM & 0.39 & 0.37 & 0.029 & 0.069 \\
\hline $\begin{array}{l}\text { FFU/kg ECM } \\
\text { (with LWC) }\end{array}$ & 0.38 & 0.36 & 0.023 & 0.11 \\
\hline \multicolumn{5}{|l|}{ Utilization of ME } \\
\hline kl & 0.61 & 0.65 & 0.05 & 0.055 \\
\hline kl (with LWC) & 0.64 & 0.68 & 0.05 & 0.10 \\
\hline
\end{tabular}

TRSM = Öpex-treated RSM (heat-moisture treatment); both Opex-treated and untreated RSM were 0 -varieties 
Feed intake and milk production in trial 3
A $\quad$ B $\quad$ C
C D E
Control TRSM12 TRSM24 RSM24 RSM24
S.E. Significance (P-value)
00-var. 00-var. 0-var. $\mathrm{FeSO}_{4}$
Between Contrast

$\begin{array}{lllll}\text { diets } & \mathrm{C} 1 & \mathrm{C} 2 & \mathrm{C} 3 & \mathrm{C} 4\end{array}$

\begin{tabular}{|c|c|c|c|c|c|c|c|c|c|c|c|}
\hline \multicolumn{12}{|l|}{ DM intake (kg/d) } \\
\hline Forage & 8.91 & 9.43 & 9.79 & 9.64 & 9.22 & 0.51 & 0.006 & $<0.001$ & 0.68 & 0.08 & 0.02 \\
\hline Grain & 6.76 & 6.19 & 5.35 & 5.34 & 5.31 & 0.18 & $<0.001$ & $<0.001$ & 0.07 & 0.79 & 0.68 \\
\hline RSM & 0.00 & 0.84 & 1.69 & 1.70 & 1.70 & 0.02 & $<0.001$ & $<0.001$ & 0.73 & 0.89 & 0.47 \\
\hline Total & 15.91 & 16.71 & 17.08 & 16.92 & 16.47 & 0.51 & $<0.001$ & $<0.001$ & 0.28 & 0.06 & 0.01 \\
\hline \multicolumn{12}{|l|}{ Milk production } \\
\hline Milk (kg/d) & 24.01 & 25.11 & 24.98 & 25.73 & 24.74 & 0.90 & 0.005 & 0.02 & 0.09 & 0.02 & 0.55 \\
\hline ECM (kg/d) & 23.53 & 24.88 & 24.83 & 25.07 & 25.26 & 0.89 & 0.002 & 0.003 & 0.05 & 0.64 & 0.29 \\
\hline Fat $(\mathrm{g} / \mathrm{d})$ & 1008 & 1060 & 1064 & 1064 & 1096 & 57 & 0.034 & 0.04 & 0.29 & 0.23 & 0.23 \\
\hline Protein (g/d) & 713 & 766 & 756 & 764 & 770 & 26 & $<0.001$ & 0.001 & 0.004 & 0.61 & 0.22 \\
\hline Lactose $(\mathrm{g} / \mathrm{d})$ & 1062 & 1120 & 1115 & 1148 & 1102 & 48 & 0.008 & 0.02 & 0.10 & 0.04 & 0.54 \\
\hline \multicolumn{12}{|l|}{ Milk composition } \\
\hline Fat $(\mathrm{g} / \mathrm{kg})$ & 41.6 & 41.8 & 42.0 & 41.1 & 43.7 & 2.2 & 0.15 & 0.69 & 1.00 & 0.17 & 0.11 \\
\hline Protein $(\mathrm{g} / \mathrm{kg})$ & 29.8 & 30.6 & 30.3 & 29.9 & 31.1 & 1.1 & 0.08 & 0.35 & 0.20 & 0.02 & 0.10 \\
\hline Lactose (g/kg) & 44.3 & 44.8 & 44.7 & 44.6 & 44.6 & 0.6 & 0.55 & 0.17 & 0.32 & 1.00 & 0.81 \\
\hline $\begin{array}{l}\text { Urea } \\
\mathrm{mg} / 100 \mathrm{ml} \text { ) }\end{array}$ & 22.4 & 26.8 & 30.1 & 29.6 & 27.7 & 2.5 & $<0.001$ & $<0.001$ & 0.52 & 0.12 & 0.049 \\
\hline Live weight (kg) & 548.6 & 551.5 & 551.1 & 551.3 & 556.3 & 9.9 & 0.54 & 0.58 & 0.68 & 0.27 & 0.25 \\
\hline $\begin{array}{l}\text { Live weight change } \\
(\mathrm{kg} / \mathrm{d})\end{array}$ & 0.13 & 0.20 & 0.27 & 0.25 & -0.03 & 0.38 & 0.41 & 0.41 & 1.00 & 0.11 & 0.08 \\
\hline $\mathrm{CP}$ intake $(\mathrm{g} / \mathrm{d})$ & 2476 & 2781 & 2994 & 2987 & 2911 & 100 & $<0.001$ & $<0.001$ & 0.25 & 0.10 & 0.08 \\
\hline \multicolumn{12}{|l|}{ Energy intake } \\
\hline $\mathrm{ME}(\mathrm{MJ} / \mathrm{d})$ & 178.3 & 188.2 & 190.1 & 189.3 & 184.3 & 7.1 & 0.005 & 0.001 & 0.15 & 0.13 & 0.08 \\
\hline NEL (MJ/d) & 108.1 & 112.7 & 114.2 & 113.3 & 111.3 & 3.2 & 0.003 & $<0.001$ & 0.23 & 0.17 & 0.05 \\
\hline FFU/d & 14.64 & 15.21 & 15.40 & 15.28 & 15.00 & 0.41 & 0.003 & $<0.001$ & 0.24 & 0.15 & 0.04 \\
\hline \multicolumn{12}{|l|}{ Feed conversion } \\
\hline FFU/kg ECM & 0.42 & 0.42 & 0.42 & 0.42 & 0.43 & 0.034 & 0.68 & 0.68 & 1.00 & 0.52 & 0.75 \\
\hline $\begin{array}{l}\text { FFU/kg ECM } \\
\text { (with LWC) }\end{array}$ & 0.43 & 0.42 & 0.43 & 0.42 & 0.43 & 0.033 & 0.68 & 0.75 & 0.79 & 0.50 & 0.74 \\
\hline \multicolumn{12}{|l|}{ Utilization of ME } \\
\hline kl & 0.61 & 0.59 & 0.58 & 0.59 & 0.64 & 0.05 & 0.16 & 0.29 & 0.99 & 0.01 & 0.002 \\
\hline kl (with LWC) & 0.64 & 0.63 & 0.64 & 0.66 & 0.63 & 0.13 & 0.07 & 0.99 & 0.99 & 0.94 & 0.99 \\
\hline
\end{tabular}

TRSM = Opex-treated turnip rapeseed meal (heat-moisture treatment); Contrasts: C1 = linear effect of RSM, C2 = quadratic effect of RSM, C3 = effect of rapeseed variety (D vs. E), C4 = the effect of Öpex-treatment (C vs. E). In contrasts C3 and $\mathrm{C} 4$ the effect of $\mathrm{FeSO}_{4}$-treatment is confounded) 
Feed intake and milk production in trial 4

\begin{tabular}{|c|c|c|c|c|c|c|c|c|c|c|}
\hline & $\begin{array}{l}\text { A } \\
\text { Control }\end{array}$ & $\begin{array}{l}\text { B } \\
\text { TRSM } \\
8 \%\end{array}$ & $\begin{array}{l}\text { C } \\
\text { TRSM } \\
16 \%\end{array}$ & $\begin{array}{l}\text { D } \\
\text { TRSM } \\
24 \%\end{array}$ & Silage & Hay & S.E. & $\begin{array}{l}\text { Signifi } \\
\text { contras } \\
\text { (P-valu } \\
\text { linear }\end{array}$ & $\begin{array}{l}\text { ance betw } \\
\text { e) } \\
\text { qudratic }\end{array}$ & veen \\
\hline \multicolumn{11}{|l|}{ DM intake $(\mathrm{kg} / \mathrm{d})$} \\
\hline Forage & 7.41 & 7.20 & 7.35 & 7.33 & 7.22 & 7.42 & 0.44 & 0.83 & 0.40 & 0.31 \\
\hline Grain & 6.35 & 5.96 & 5.44 & 4.93 & 5.69 & 5.64 & 0.05 & & & \\
\hline RSM & 0.00 & 0.52 & 1.03 & 1.56 & 0.78 & 0.77 & 0.02 & & & \\
\hline Total & 13.96 & 13.89 & 14.03 & 14.02 & 13.90 & 14.05 & 0.44 & 0.51 & 0.77 & 0.48 \\
\hline \multicolumn{11}{|l|}{ Milk production } \\
\hline Milk (kg/d) & 17.04 & 17.34 & 17.96 & 18.04 & 17.85 & 17.34 & 0.90 & 0.001 & 0.62 & 0.39 \\
\hline ECM (kg/d) & 18.59 & 18.64 & 19.37 & 19.35 & 19.06 & 18.92 & 0.62 & $<0.001$ & 0.81 & 0.047 \\
\hline Fat $(\mathrm{g} / \mathrm{d})$ & 808 & 805 & 834 & 832 & 829 & 811 & 30.6 & 0.007 & 0.99 & 0.084 \\
\hline Protein (g/d) & 574 & 576 & 606 & 599 & 581 & 596 & 21.9 & $<0.001$ & 0.42 & 0.012 \\
\hline Lactose (g/d) & 799 & 812 & 839 & 850 & 829 & 821 & 47.7 & 0.002 & 0.94 & 0.60 \\
\hline \multicolumn{11}{|l|}{ Milk composition } \\
\hline Fat $(\mathrm{g} / \mathrm{kg})$ & 47.8 & 46.8 & 46.6 & 46.5 & 46.9 & 47.0 & 47.7 & 0.002 & 0.94 & 0.60 \\
\hline Protein (g/kg) & 34.0 & 33.4 & 33.9 & 33.4 & 32.8 & 34.5 & 2.6 & 0.17 & 0.50 & 0.81 \\
\hline Lactose $(\mathrm{g} / \mathrm{kg})$ & 46.9 & 46.7 & 46.8 & 47.0 & 46.3 & 47.4 & 0.7 & 0.63 & 0.21 & 0.95 \\
\hline Urea $(\mathrm{mg} / 100 \mathrm{ml})$ & 26.5 & 29.0 & 31.0 & 33.1 & 28.0 & 31.9 & 1.3 & $<0.001$ & 0.56 & 0.66 \\
\hline Live weight $(\mathrm{kg})$ & 516.3 & 516.6 & 517.6 & 516.5 & 518.8 & 514.7 & 10.0 & 0.89 & 0.77 & 0.81 \\
\hline $\begin{array}{l}\text { Live weight change } \\
(\mathrm{kg} / \mathrm{d})\end{array}$ & 0.14 & 0.19 & 0.21 & 0.14 & 0.17 & 0.17 & 0.24 & 1.00 & 0.32 & 0.82 \\
\hline $\mathrm{CP}$ intake $(\mathrm{g} / \mathrm{d})$ & 2078 & 2162 & 2296 & 2397 & 2154 & 2312 & 79 & $<0.001$ & 0.66 & 0.36 \\
\hline \multicolumn{11}{|l|}{ Energy intake } \\
\hline $\mathrm{ME}(\mathrm{MJ} / \mathrm{d})$ & 161.3 & 160.4 & 161.3 & 160.7 & 163.2 & 158.7 & 4.6 & 0.86 & 0.88 & 0.50 \\
\hline NEL (MJ/d) & 92.8 & 92.3 & 93.0 & 92.7 & 92.8 & 92.6 & 2.6 & 1.00 & 0.88 & 0.52 \\
\hline $\mathrm{FFU} / \mathrm{d}$ & 12.50 & 12.44 & 12.49 & 12.44 & 12.71 & 12.23 & 0.32 & 0.74 & 1.00 & 0.56 \\
\hline \multicolumn{11}{|l|}{ Feed conversion } \\
\hline FFU/kg ECM & 0.46 & 0.45 & 0.44 & 0.44 & 0.46 & 0.43 & 0.022 & 0.005 & 0.65 & 0.27 \\
\hline FFU/kg ECM & 0.43 & 0.42 & 0.41 & 0.42 & 0.43 & 0.41 & 0.034 & 0.093 & 0.23 & 0.61 \\
\hline \multicolumn{11}{|l|}{ Utilization of ME } \\
\hline kl & 0.52 & 0.53 & 0.55 & 0.55 & 0.53 & 0.55 & 0.029 & 0.014 & 0.55 & 0.69 \\
\hline kl (with LWC) & 0.57 & 0.59 & 0.60 & 0.59 & 0.58 & 0.60 & 0.056 & 0.19 & 0.24 & 0.90 \\
\hline
\end{tabular}

TRSM = Öpex-treated rapeseed meal (00-variety) 
Feed intake and milk production in trial 5

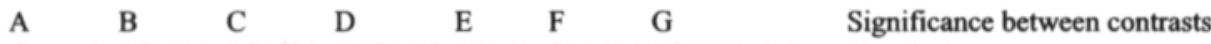
Control RSM12 RSM24 TRSM12 SBM8 SBM16 TSBM8 S.E. (P-value)

$\mathrm{C} 1 \quad \mathrm{C} 2 \quad \mathrm{C} 3 \quad \mathrm{C} 4$

\begin{tabular}{|c|c|c|c|c|c|c|c|c|c|c|c|c|}
\hline \multicolumn{13}{|l|}{ DM intake $(\mathrm{kg} / \mathrm{d})$} \\
\hline Forage & 11.68 & 11.49 & 11.56 & 11.53 & 11.79 & 11.52 & 10.92 & 0.76 & 0.79 & 0.73 & 0.93 & 0.66 \\
\hline Grain & 5.90 & 5.54 & 4.95 & 5.64 & 5.66 & 5.31 & 5.55 & 0.26 & & & & \\
\hline RSM/SBM & 0.00 & 0.77 & 1.60 & 0.78 & 0.52 & 1.07 & 0.53 & 0.04 & & & & \\
\hline Total & 17.81 & 18.06 & 18.38 & 18.21 & 18.24 & 18.17 & 17.26 & 0.75 & 0.17 & 0.92 & 0.71 & 0.21 \\
\hline \multicolumn{13}{|l|}{ Milk production } \\
\hline Milk (kg/d) & 23.29 & 24.10 & 25.22 & 23.19 & 24.26 & 24.21 & 22.93 & 1.41 & 0.019 & 0.82 & 0.25 & 0.45 \\
\hline $\operatorname{ECM}(\mathrm{kg} / \mathrm{d})$ & 24.27 & 25.27 & 26.44 & 24.75 & 26.02 & 25.79 & 24.22 & 1.61 & 0.020 & 0.90 & 0.57 & 0.80 \\
\hline Fat $(\mathrm{g} / \mathrm{d})$ & 1040 & 1093 & 1134 & 1081 & 1134 & 1115 & 1055 & 87.5 & 0.060 & 0.89 & 0.80 & 0.97 \\
\hline Protein $(\mathrm{g} / \mathrm{d})$ & 759 & 782 & 829 & 769 & 812 & 806 & 750 & 45.7 & 0.009 & 0.59 & 0.59 & 0.81 \\
\hline Lactose $(\mathrm{g} / \mathrm{d})$ & 1062 & 1094 & 1152 & 1046 & 1098 & 1107 & 1030 & 64.6 & 0.017 & 0.67 & 0.18 & 0.40 \\
\hline \multicolumn{13}{|l|}{ Milk composition } \\
\hline Fat $(\mathrm{g} / \mathrm{kg})$ & 45.3 & 45.5 & 45.1 & 46.8 & 46.5 & 46.1 & 46.2 & 2.4 & 0.88 & 0.76 & 0.33 & 0.60 \\
\hline Protein $(\mathrm{g} / \mathrm{kg})$ & 32.8 & 32.6 & 32.9 & 33.2 & 33.5 & 33.3 & 33.0 & 0.75 & 0.77 & 0.48 & 0.16 & 0.14 \\
\hline Lactose $(\mathrm{g} / \mathrm{kg})$ & 45.5 & 45.3 & 45.7 & 45.2 & 45.2 & 45.7 & 44.9 & 0.73 & 0.52 & 0.43 & 0.72 & 0.64 \\
\hline Urea $(\mathrm{mg} / 100 \mathrm{ml})$ & 21.7 & 26.8 & 29.6 & 25.4 & 27.6 & 30.5 & 27.0 & 2.4 & $<0.001$ & 0.32 & 0.31 & 0.20 \\
\hline Live weight (kg) & 574.4 & 577.5 & 578.9 & 580.0 & 574.4 & 574.6 & 578.5 & 6.6 & 0.22 & 0.79 & 0.49 & 0.20 \\
\hline $\begin{array}{l}\text { Live weight change } \\
\quad(\mathrm{kg} / \mathrm{d})\end{array}$ & 0.46 & 0.20 & 0.54 & 0.40 & 0.04 & 0.55 & 0.00 & 0.39 & 0.71 & 0.11 & 0.35 & 0.19 \\
\hline $\mathrm{CP}$ intake $(\mathrm{g} / \mathrm{d})$ & 2817 & 3058 & 3232 & 2902 & 3035 & 3293 & 3056 & 125 & $<0.001$ & 0.75 & 0.77 & 0.17 \\
\hline \multicolumn{13}{|l|}{ Energy intake } \\
\hline $\mathrm{ME}(\mathrm{MJ} / \mathrm{d})$ & 206.3 & 208.5 & 211.2 & 210.5 & 211.2 & 210.3 & 200.1 & 8.3 & 0.29 & 0.95 & 0.66 & 0.33 \\
\hline NEL (MJ/d) & 118.2 & 119.6 & 121.2 & 120.8 & 121.1 & 120.8 & 114.8 & 4.8 & 0.26 & 0.96 & 0.64 & 0.33 \\
\hline FFU/d & 15.62 & 15.82 & 16.02 & 15.99 & 16.02 & 15.98 & 15.21 & 0.60 & 0.23 & 0.99 & 0.61 & 0.34 \\
\hline \multicolumn{13}{|l|}{ Feed conversion } \\
\hline FFU/kg ECM & 0.46 & 0.46 & 0.44 & 0.47 & 0.46 & 0.45 & 0.45 & 0.023 & 0.04 & 0.60 & 0.31 & 0.92 \\
\hline $\begin{array}{l}\text { FFU/kg ECM } \\
\text { (with LWC) }\end{array}$ & 0.42 & 0.43 & 0.39 & 0.43 & 0.45 & 0.40 & 0.45 & 0.042 & 0.19 & 0.10 & 0.84 & 0.24 \\
\hline \multicolumn{13}{|l|}{ Utilization of ME } \\
\hline kl & 0.51 & 0.52 & 0.54 & 0.51 & 0.53 & 0.53 & 0.53 & 0.03 & 0.052 & 0.91 & 0.33 & 0.71 \\
\hline kl (with LWC) & 0.60 & 0.56 & 0.67 & 0.59 & 0.54 & 0.64 & 0.55 & 0.10 & 0.089 & 0.06 & 0.55 & 0.28 \\
\hline
\end{tabular}

Rapeseed meal is 00-variety; T means heat-moisture treatment (Öpex) for RSM and SBM

Contrasts: $\mathrm{C} 1$ = linear effect of RSM, C2 = quadratic effect of RSM, C3 = effect of heat treatment of RSM, C4 RSM vs. SBM 